\title{
REMOTE-HANDLED TRANSURANIC WASTE STUDY
}

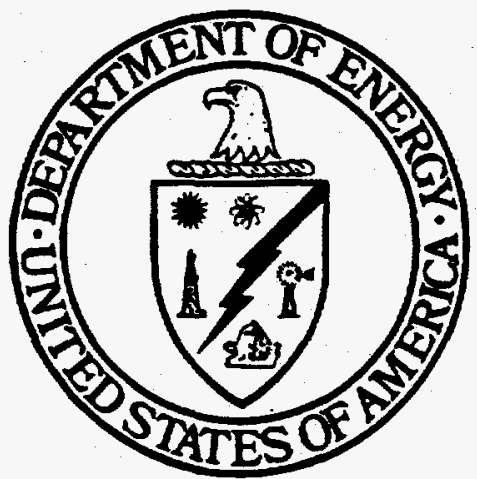

\section{U.S. Department of Energy}

Carlsbad Area Office

Carlsbad, New Mexico

October 1995 


\section{DISCLAMMIER}

Portions of this document may be illegible in electronic image products. Images are produced from the best available original document. 
This document has been reproduced directly from the best possible copy. It is available to DOE and DOE contractors at the following address:

Office of Scientific and Technical Information

P. O. Box 62

Oak Ridge, TN 37831

Prices available from (615) $576-8401$

\author{
Available to the public from the \\ National Technical Information Service \\ U. S. Department of Commerce \\ 5285 Port Royal Road \\ Springfield, VA 22161
}

\title{
DISCLAIMER
}

This report was prepared as an account of work sponsored by an agency of the United States Government. Neither the United States Government nor any agency thereof, nor any of their employees, makes any warranty, express or implied, or assumes any legal liability or responsibility for the accuracy, completeness, or usefulness of any information, apparatus, product, or process disclosed, or represents that its use would not infringe privately owned rights. Reference herein to any specific commercial product, process, or service by trade name, trademark, manufacturer, or otherwise does not necessarily constitute or imply its endorsement, recommendation, or favoring by the United States Government or any agency thereof. The views and opinions of authors expressed herein do not necessarily state or reflect those of the United States Government or any agency thereof. 
Section

ACRONYMS AND ABBREVIATIONS $\ldots \ldots \ldots \ldots \ldots \ldots \ldots \ldots \ldots \ldots \ldots \ldots \ldots$

EXECUTIVE SUMMARY $\ldots \ldots \ldots \ldots \ldots \ldots \ldots \ldots \ldots \ldots \ldots \ldots \ldots$ vii

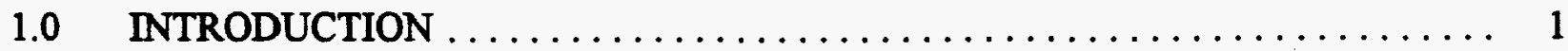

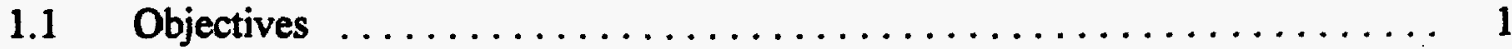

1.2 Background $\ldots \ldots \ldots \ldots \ldots \ldots \ldots \ldots \ldots \ldots \ldots \ldots \ldots, 2$

2.0 THE TRANSURANIC WASTE DISPOSAL STRATEGY $\ldots \ldots \ldots \ldots \ldots \ldots$

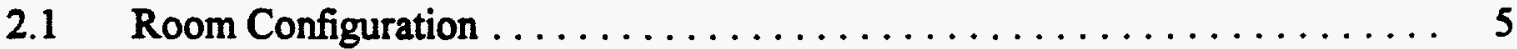

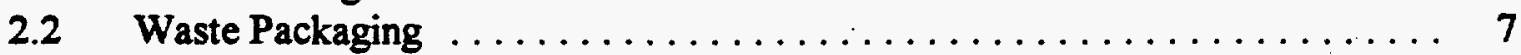

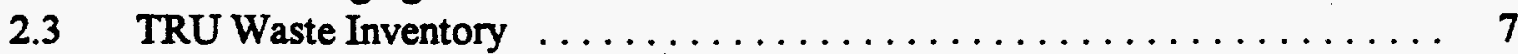

3.0 COMPARISON OF CONTACT-HANDLED AND REMOTE-HANDLED TRANSURANIC WASTES $\ldots \ldots \ldots \ldots \ldots \ldots \ldots \ldots \ldots \ldots \ldots \ldots$

3.1 "As-Received" Inventory Description and Comparison $\ldots \ldots \ldots \ldots \ldots \ldots 11$

3.1.1 TRU Waste Inventory . . . . . . . . . . . . . . . . . . . . . 14

3.1.2 TRU Radionuclide Inventory $\ldots \ldots \ldots \ldots \ldots \ldots \ldots \ldots \ldots \ldots$

3.2 Comparison of LWA Issues During the Post-Closure Period . . . . . . . . . 19

3.2.1 Gas Generation ........................... 19

3.2.2 Flammability and Explosiveness $\ldots \ldots \ldots \ldots \ldots \ldots \ldots \ldots \ldots \ldots \ldots \ldots \ldots \ldots$

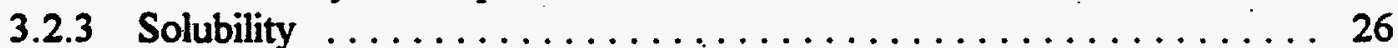

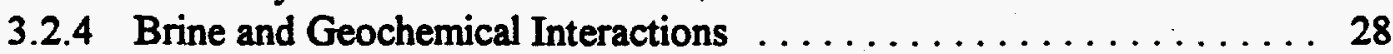

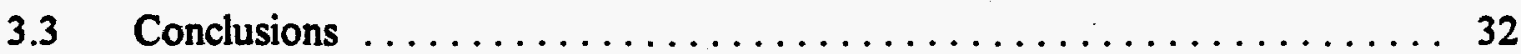

4.0 ANALYSIS OF THE IMPACT OF REMOTE-HANDLED WASTE ON PERFORMANCE ASSESSMENT $\ldots \ldots \ldots \ldots \ldots \ldots \ldots \ldots \ldots \ldots \ldots$

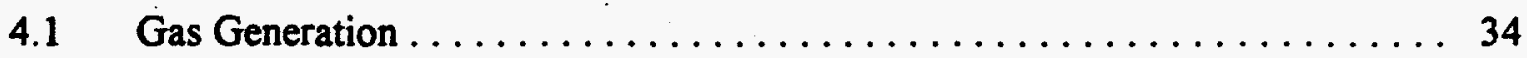

4.2 Radionuclide Migration by Groundwater Transport $\ldots \ldots \ldots \ldots \ldots \ldots 35$

4.3 Cuttings Releases by Human Intrusion $\ldots \ldots \ldots \ldots \ldots \ldots \ldots \ldots \ldots \ldots \ldots \ldots \ldots$

4.4 Radiolytic Heat Generation . . . . . . . . . . . . . . . . . . . 40

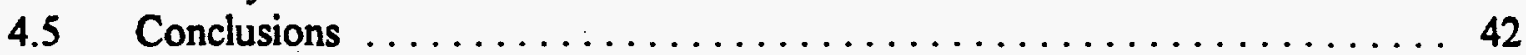

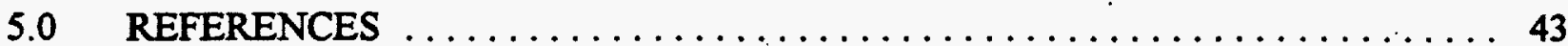

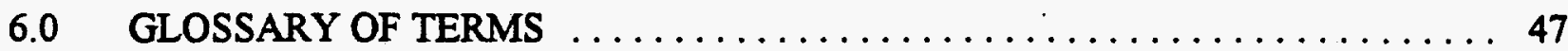


A RH-TRU SHIELD PLUG AND CANISTER DESCRIPTION $\ldots \ldots \ldots \ldots \ldots \ldots$ A-1

B DISPOSAL RADIONUCLIDE INVENTORY $\ldots \ldots \ldots \ldots \ldots \ldots \ldots$ B-1

C ORIGEN MODEL RESULTS FOR RADIONUCLIDE ACTIVITY, 0-10,000 YEARS, AND RADIONUCLIDE DECAY SERIES

D GAS GENERATION MECHANISMS $\ldots \ldots \ldots \ldots \ldots \ldots \ldots \ldots \ldots \ldots$ D-1

E ANALYSIS SUPPORTING EVALUATION OF BRINE AND GEOCHEMICAL

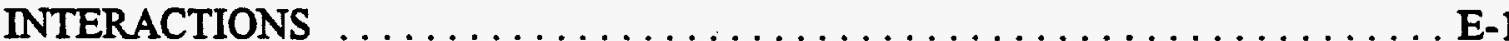




\section{LIST OF FIGURES}

Figure

2-1 WIPP Disposal Room Configuration $\ldots \ldots \ldots \ldots \ldots \ldots \ldots \ldots \ldots \ldots$

3-1 RH Radionuclide Inventory as a Percentage of the Total Radionuclide Inventory During Post-Closure Period . . . . . . . . . . . . . . . . . . . 18

3-2 Formation Absorbed Dose as a Function of Time $\ldots \ldots \ldots \ldots \ldots \ldots \ldots$

4-1 CUTTINGS Model CCDFs $\ldots \ldots \ldots \ldots \ldots \ldots \ldots \ldots \ldots \ldots \ldots \ldots$

\section{LIST OF TABLES}

Table

3-1 Estimated Transuranic Waste Disposal Inventory for WIPP . . . . . . . . . 15

3-2 Waste Material Parameters and Packaging that Contribute to Flammable Gas Generation

4-1 Projected Activity Levels $\left(\mathrm{Ci} / \mathrm{m}^{2}\right)$ in the WIPP Due to Waste That Is Currently Stored and May Be Shipped to the WIPP 


\section{ACRONYMS AND ABBREVIATIONS}

\begin{tabular}{ll} 
ASME & American Society of Mechanical Engineers \\
ASTM & American Society for Testing and Materials \\
atm & atmosphere \\
BNL & Brookhaven National Laboratory \\
BRAGFLO & Brine and Gas Flow Model (a performance assessment model) \\
CAO & Carlsbad Area Office \\
C\&C & Consultation and Cooperation \\
CCDF & complementary cumulative distribution function \\
CFR & Code of Federal Regulations \\
CH & contact-handled \\
Cs & Cesium \\
$\mathrm{C}$ & degrees centigrade/Celsius \\
DOE & U.S. Department of Energy \\
DOT & U.S. Department of Transportation \\
DRZ & disturbed rock zone \\
Eh & oxidation-reduction potential \\
EPA & U.S. Environmental Protection Agency \\
eV & electron volt \\
FEPs & features, events, and processes \\
$\mathrm{ft}^{3}$ & cubic foot/feet \\
$\mathrm{g}$ & gram(s) \\
$\mathrm{G}-\mathrm{value}$ & gas molecules per 100 eV \\
$\mathrm{HEPA}$ & high-efficiency particulate air \\
$\mathrm{HLW}$ & high-level waste \\
$\mathrm{hr}$ & hour(s) \\
$\mathrm{IDB}$ & Integrated Database \\
$\mathrm{I}$ & radiation exposure rate \\
$\mathrm{kg}$ & kilogram(s) \\
$\mathrm{kg} / \mathrm{m}^{3}$ & kilogram(s) per cubic meter \\
$\mathrm{LEL}$ & lower explosive limit \\
$\mathrm{LWA}$ & Land Withdrawal Act \\
$\mathrm{M}$ & molar \\
$\mathrm{m}^{2}$ & square meter(s) \\
$\mathrm{m}^{3}$ & cubic meter(s) \\
$\mu \mathrm{m}$ & micrometer(s) \\
$\mu \mathrm{s}$ & microsecond(s) \\
$\mathrm{min}$ & minimum \\
$\mathrm{mL}$ & milliliter \\
$\mathrm{mrem} / \mathrm{hr}$ & millirem(s) per hour \\
$\mathrm{nCi} / \mathrm{g}$ & nanocurie(s) per gram \\
$\mathrm{NMD}$ & No-Migration Determination \\
$\mathrm{NRC}$ & U.S. Nuclear Regulatory Commission \\
\hline
\end{tabular}




\begin{tabular}{ll} 
ORIGEN2 & Oak Ridge Isotope Generation \\
ORNL & Oak Ridge National Laboratory \\
OSHA & Occupational Safety and Health Administration \\
PA & performance assessment \\
pH & negative log ${ }_{10}$ of the hydrogen ion concentration (a measure of acidity) \\
PNL & Pacific Northwest Laboratories \\
ppm & parts per million \\
QAPP & Quality Assurance Program Plan \\
RCRA & Resource Conservation and Recovery Act \\
rem & roentgen equivalent man (a unit of radiation dose) \\
rem/hr & rem(s) per hour \\
RH & remote-handled \\
TRAMPAC & Transuranic Waste Authorized Methods of Payload Control \\
SAR & Safety Analysis Report \\
sec & second(s) \\
SNL & Sandia National Laboratories \\
SPM & System Prioritization Method \\
Sr & Strontium \\
SWB & Standard Waste Box \\
TDO & Ten Drum Overpack \\
TRU & transuranic \\
TRUPACT & Transuranic Package Transporter \\
UEL & Upper Explosive Limit \\
VOC & volatile organic compound \\
W & watt \\
WAC & Waste Acceptance Criteria \\
WHPP & Waste Handling and Packaging Plant \\
WIPP & Waste Isolation Pilot Plant \\
WTSD & Waste Technology Services Division \\
WTWBIR & Waste Isolation Pilot Plant Transuranic Waste Baseline Inventory Report \\
yr & year(s) \\
\hline
\end{tabular}




\section{EXECUTIVE SUMMARY}

The Waste Isolation Pilot Plant (WIPP) was developed by the U.S. Department of Energy (DOE) as a research and development facility to demonstrate the safe disposal of transuranic (TRU) radioactive wastes generated from the Nation's defense activities. One of the primary goals of the DOE waste program is to terminate interim storage [Public Law 96-164, 1979] and to achieve permanent disposal of DOE TRU defense wastes. The WIPP disposal inventory will consist of 6.2 million cubic feet $\left(-176,000 \mathrm{~m}^{3}\right)$ of TRU wastes, which includes up to 250,000 cubic feet $\left(7,080 \mathrm{~m}^{3}\right)$ of TRU wastes classified as remote handled (RH). The remaining inventory will include contact-handled (CH) TRU wastes, which characteristically have less specific activity (radioactivity per unit volume) than the RH-TRU wastes.

Disposal of RH-TRU waste will have a minimal impact on the long-term performance of the WIPP repository. The WIPP Land Withdrawal Act (LWA), Public Law 102-579, requires a study of the effect of RH-TRU waste on long-term performance. However, the most significant concern with RH-TRU waste is relative to the operational aspects for handling this type of waste, which has been addressed in previous studies. Because of the penetrating radiation associated with RH-TRU wastes, special equipment and facilities are required for disposal operations. The WIPP has existing equipment and facilities designed for handling these wastes in a safe and efficient manner.

This RH-TRU Waste Study has been conducted to satisfy the requirements defined by the LWA and is considered by the DOE to be a prudent exercise in the compliance certification process of the WIPP repository. The specific project requirements for the RH-TRU waste study are addressed in Section 6(c)(2)(B) of the LWA [Public Law 102-579, 1992] under WIPP test phase activities limitations. The LWA includes several restrictions on actual waste experiments once planned at WIPP during the test phase, including prohibiting the use of RH-TRU wastes. In lieu of conducting experiments with RH-TRU wastes, the LWA includes requirements for DOE to conduct a study to evaluate the impacts of RH-TRU wastes on the repository. The objectives of this study include: 
- Conducting an evaluation of the impacts of RH-TRU wastes on the performance assessment (PA) of the repository to determine the effects of RH-TRU waste as a part of the total WIPP disposal inventory; and

- Conducting a comparison of CH-TRU and RH-TRU wastes to assess the differences and similarities for such issues as gas generation, flammability and explosiveness, solubility, and brine and geochemical interactions.

This study was conducted using the data, models, computer codes, and information generated in support of long-term compliance programs, including the WIPP PA. The study is limited in scope to post-closure repository performance and includes an analysis of the issues associated with RH-TRU wastes subsequent to emplacement of these wastes at WIPP in consideration of the current baseline design. Operational and transportation elements of the RH-TRU waste program are not assessed in this document.

The RH-TRU waste inventory to be disposed in WIPP has primarily the same physical characteristics as those of $\mathrm{CH}$-TRU wastes. These characteristics are identified as those parameters that have the potential to impact repository performance under anticipated repository conditions. The important waste material parameters (as defined by performance assessment) for CH:TRU and RH-TRU wastes are the basis for the Waste Isolation Pilot Plant Transuranic Waste Baseline Inventory Report (WTWBIR), which includes a survey of the quantity of each waste material parameter (e.g., metals, cellulosics, and plastics), as well as the radionuclide content. The WTWBIR provides the waste inventory definition used in this RH-TRU waste study as well as performance assessment modeling.

CH-TRU and RH-TRU wastes contain the same radioactive materials (radionuclides). The two types of wastes are differentiated by the relative quantities of these radionuclides. The distinguishing difference between CH-TRU and RH-TRU wastes is the specific radioactivity of relatively short-lived beta and gamma emitters, including the fission and activation products that are characteristic of RH-TRU wastes. Although the CH-TRU inventory includes a minor amount of short-lived radionuclides relative to the RH-TRU inventory, the predominant radioactivity is from long-lived alpha emitters that exhibit minimal beta and gamma emissions and have a lower specific radioactivity. 
Because gamma radiation is more penetrating than alpha radiation, gamma emitters require additional shielding while being handled beyond that required for $\mathrm{CH}$-TRU waste. The relatively rapid decay of RH-TRU beta and gamma radionuclides with half-lives of 30 years or less results in low $\left(<10 \mathrm{Ci} / \mathrm{m}^{3}\right)$ radioactivities within about 200 years. After this period, the $\mathrm{CH}-\mathrm{TRU}$ and RH-TRU waste forms will consist of similar radionuclide inventories and therefore can reasonably be assumed to impact the repository by a degree proportional to the additional mass of the RH-TRU inventory.

As this study demonstrates, the inclusion of approximately 5 percent by volume of RH-TRU waste in the disposal inventory is essentially indistinguishable from an inventory that is limited to only contact-handled waste in the analytical assessment of long-term performance of the repository. This study concludes that CH-TRU and RH-TRU wastes are very similar with respect to the expected contribution of gas generation, flammability and explosiveness, solubility, and brine and geochemical interactions within the disposal system. The evaluation of the impact of RH-TRU on PA concluded that its effect on the repository performance will be negligible over the 10,000-year regulatory period. This is because RH-TRU is limited to only 5 percent of the waste volume, the waste materials are very similar, and radionuclides in the $\mathrm{RH}$ inventory will decay to activities less than that in the $\mathrm{CH}$ inventory within about 200 years. 


\subsection{INTRODUCTION}

The Waste Isolation Pilot Plant (WIPP) Land Withdrawal Act (LWA), Public Law 102-579, requires that a study be conducted of remote-handled $(\mathrm{RH})$ transuranic (TRU) waste prior to initial receipt of waste in WIPP. In addition, the DOE considers the study to be a prudent exercise in the compliance certification process of the WIPP repository. The specific project requirements for the RH-TRU waste study are addressed in the LWA, Section 6(c)(2)(B) under the WIPP test phase activities. As specified in the law, the RH-TRU waste study shall include an analysis of the impact of RH-TRU waste on the performance assessment (PA) of the WIPP and a comparison of RH-TRU waste with CH-TRU waste.

\subsection{Objectives}

The objectives of this study include:

- Conducting an analysis of the impacts of RH-TRU wastes on the PA of the repository to determine the effects of RH-TRU waste as a part of the total WIPP disposal inventory; and

- Conducting a comparison of CH-TRU and RH-TRU wastes to assess the differences and similarities for such issues as gas generation, flammability and explosiveness, solubility, and brine and geochemical interactions.

These analyses address the elements of CH-TRU and RH-TRU wastes that are important to an assessment of long-term compliance by WIPP. This study is consistent with the PA process and the method used for the draft compliance certification application submitted to the U.S. Environmental Protection Agency (EPA) in March 1995 [DOE, 1995a]. The waste inventory data used throughout this study represents the best available information as reported by the waste generator/storage sites. 


\subsection{Background}

The U.S. Department of Energy (DOE) and its parent Federal agencies have designed, developed, tested, and manufactured nuclear weapons for nearly 50 years. One of the by-products of these defense activities is waste that contains TRU elements. The primary types of operations that generate TRU wastes include production of weapons, plutonium $(\mathrm{Pu})$ recovery, research and development programs, and decontamination and decommissioning activities. TRU wastes are defined by DOE Order 5820.2A [DOE, 1988] as wastes that are contaminated with radionuclides that exhibit the following characteristics:

- An atomic number greater than 92 .

- Alpha-emitting transuranium radionuclides with half-lives greater than 20 years.

- Exist in the waste at concentrations greater than 100 nanocuries per gram $(\mathrm{nCi} / \mathrm{g}$ ) for any single waste package.

TRU waste is also classified according to its measured radiation level at the external surface of the waste package. Most TRU wastes (approximately 95 percent of the WIPP inventory by volume) emit primarily alpha radiation. Alpha particles are readily absorbed and lose energy on collisions; therefore, they do not represent an external radiation hazard but threaten internal tissues if inhaled or ingested. Because even the relatively low levels of beta and gamma radiation at the surfaces of CH-TRU waste containers are potentially harmful to workers, WIPP waste-handling procedures are designed to minimize worker exposure to the $\mathrm{CH}$-TRU waste drums. In addition, $\mathrm{CH}-\mathrm{TRU}$ waste packages are limited to a container surface dose of 200 millirems per hour (mrem/hr).

TRU wastes that have a measured radiation dose rate greater than $200 \mathrm{mrem} / \mathrm{hr}$ are classified as RH-TRU wastes (up to $1,000 \mathrm{rem} / \mathrm{hr}$ ). These wastes contain larger quantities of radionuclides that emit beta and gamma as well as alpha radiation. RH-TRU waste will be handled by remote methods to provide the necessary shielding to ensure worker safety during disposal. The WIPP facility is fully equipped to handle RH-TRU waste and its associated radiation. Each RH-TRU shipping cask, which will contain one canister, will be inspected and removed from the transport vehicles and transferred to the unloading room where the canisters will be removed and placed in the "hot cell." After 
inspection, the canister will be positioned in the transfer cell, loaded into a heavily shielded facility cask, and lowered underground through the waste shaft for emplacement. The facility cask will be transported to the disposal location and the canister emplaced with the facility cask held in position to provide adequate shielding at all times.

In 1992, the 102nd Congress enacted the WIPP LWA, Public Law 102-579, to withdraw the WIPP land-use area (16 square miles) from "entry, appropriation, and disposal" and to reserve the land for authorized WIPP-related activities. Jurisdiction over the WIPP land-use area was transferred from the Secretary of Interior to the Secretary of Energy. The Act also established the requirements for initiating the test phase activities and the limitations on test phase activities and established the regulatory structure for the certification by the Administrator of the EPA "whether the WIPP facility will comply with the final disposal regulations." The test phase activities and requirements focused on the proposed experiments to be conducted at WIPP using actual CH-TRU wastes from TRU waste generator/storage sites. Development of a Test Phase Plan was required to set forth the proposed test phase activities, as well as to specify the quantities of wastes needed for experimentation, to describe how the tests would provide relevant data to support a certification of compliance, and to include the necessary justification for all such activities.

The LWA also includes several restrictions on actual waste experiments at WIPP, including prohibiting the use of RH-TRU wastes during the test phase. In lieu of conducting experiments with RH-TRU wastes, the LWA includes requirements for DOE to conduct a study to analyze the impacts of RH-TRU wastes on performance of the repository. This requirement was included to ensure that the characteristics of RH-TRU wastes are considered in the long-term performance evaluations. In addition, the DOE considers the development of the RH-TRU Waste Study to be a prudent exercise in the certification process of the WIPP repository.

The specific requirements established in the LWA are stated below. 
Land Withdrawal Act, Section 6(c)(2)(B)

(B) Study.

(i) In general. Within 3 years after the date of the enactment of this Act, the Secretary shall complete a study on remote-handled transuranic waste in consultation with affected States, the Administrator, and after the solicitation of views of other interested parties.

(ii) Requirements of study. Such study shall include an analysis of the impact of remote-handled transuranic waste on the performance assessment of WIPP and a comparison of remote-handled transuranic wastes with contact-handled transuranic waste on such issues as gas generation, flammability, explosiveness, solubility, and brine and geochemical interactions.

(iii) Publication. The Secretary shall publish the findings of such study in the Federal Register.

[Public Law 102-579, 1992]

To initiate consultations as required under Section 6(c)(2)(B)(i) of the LWA, the DOE/Carisbad Area Office (CAO) distributed the Implementation Plan for the Remote Handled TRU Waste Performance Assessment and Comparison to Contact Handled TRU Waste (hereafter referred to as the Implementation Plan) [DOE, 1995b] in January 1995 for review and comment. Comments received on the Implementation Plan were considered in the development of this document. The Implementation Plan discussed the outline and anticipated technical approach to be used for this RH study. A presentation to the public and stakeholder organizations was given April 7, 1995 [DOE, 1995c] to solicit input regarding the development of the study. This study has been provided to stakeholders and the EPA for review and comment prior to final publication. The WIPP Land Withdrawal Act (Public Law 102-579) Section 6(c)(2)(B)(ii) is the basis of this document and is addressed in Chapters 3 and 4. Chapter 3 compares CH-TRU and RH-TRU wastes with respect to the LWA issues, while Chapter 4 evaluates the impact that RH-TRU waste has on PA. 


\subsection{THE TRANSURANIC WASTE DISPOSAL STRATEGY}

The strategy for disposal of defense-related TRU waste includes implementation of the necessary regulatory and programmatic activities to ensure disposal of the maximum allowable inventory, consistent with statutory and other legal limitations, that can be demonstrated to be acceptable in compliance evaluations. Several fundamental elements of the RH-TRU program are currently in the development stages. The Waste Isolation Pilot Plant Remote-Handled Transuranic Waste Disposal Strategy document [DOE, 1995d] addresses these elements and the programs that are supporting development. The Remote-Handled Transuranic Waste Study addresses only those aspects of RH-TRU wastes that pertain to the requirements defined in the LWA. The transportation elements of this program can be found in the Comparative Study of Waste Isolation Pilot Plant (WIPP) Transportation Alternatives [DOE, 1994].

RH-TRU disposal elements that are pertinent to this study include room configuration, waste packaging, shield plugs, and the physical and radiological characteristics of the RH-TRU waste inventory. The following subsections discuss the current strategy for CH-TRU and RH-TRU waste disposal.

\subsection{Room Configuration}

The waste disposal area within WIPP consists of eight panels, each containing seven rooms between access drifts. The RH-TRU wastes will be emplaced in a manner different from that for the CH-TRU wastes because of packaging, shielding, and loading requirements; operational equipment; and structural considerations. The current disposal configuration of the CH-TRU inventory includes emplacement of the waste packages in disposal rooms that measure $33 \mathrm{ft}$ wide, $13 \mathrm{ft} \mathrm{high}$, and $300 \mathrm{ft}$ long [Sandia WIPP Project, 1992] (see Figure 2-1). The current configuration for RH-TRU disposal includes emplacement into the walls in horizontal boreholes. These boreholes will be drilled 4 feet from the floor on 8-foot centers [Sandia WIPP Project, 1992]. There will be a total of approximately 7,955 RH-TRU waste boreholes. 
ROOM CROSS-SECTION
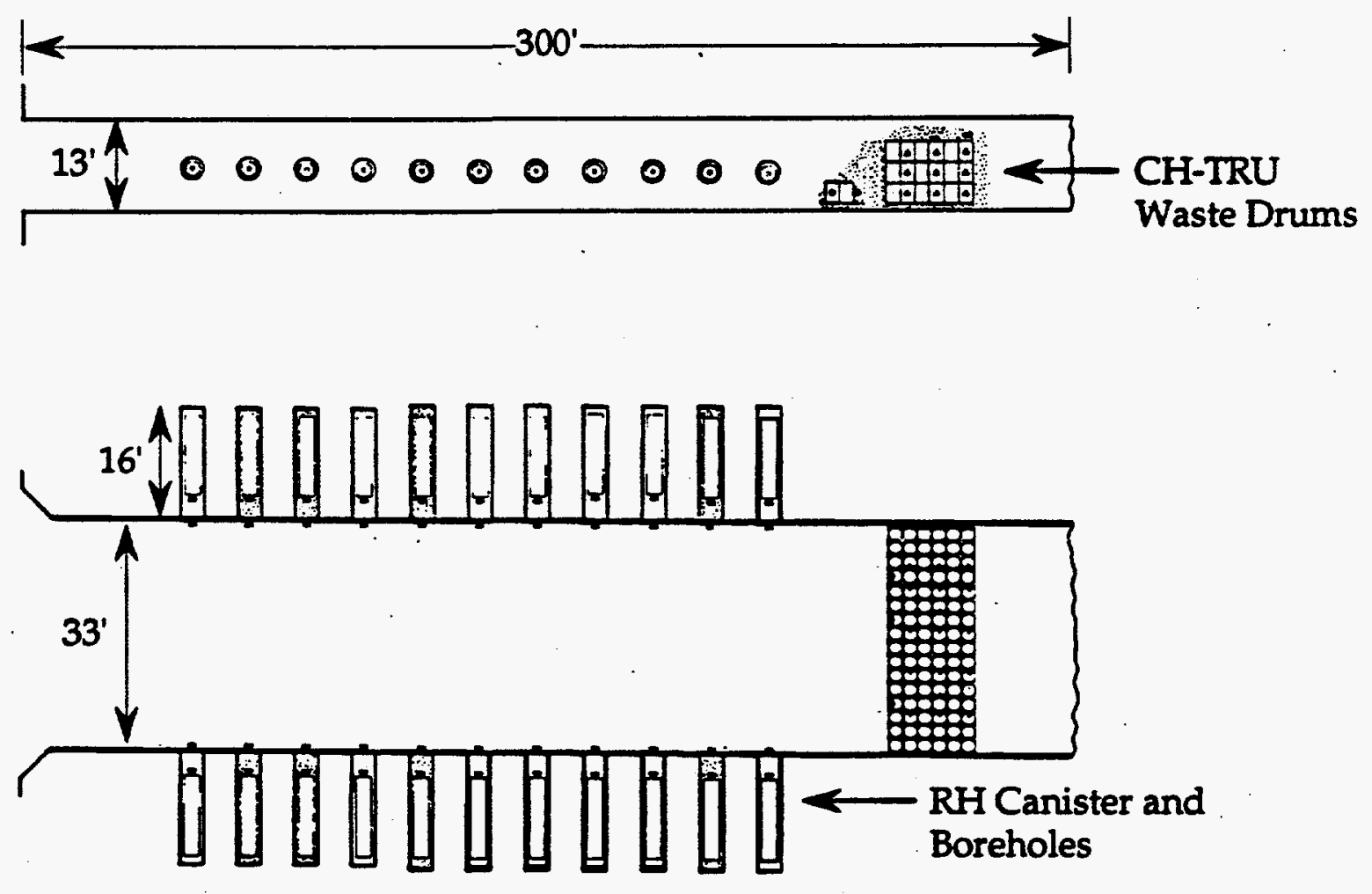

PLAN VIEW

Not to Scale

Figure 2-1. WIPP Disposal Room Configuration 
A shield plug capping each borehole after emplacement of the RH-TRU canister in the room wall will provide the necessary shielding required for worker safety. This shield plug is constructed of carbon steel and weighs approximately 4,200 pounds. Appendix A includes a description of the RH-TRU shield plug currently planned for implementation. The CH-TRU waste inventory will be emplaced in the disposal rooms following completion of all RH-TRU waste disposal activities in that room.

\subsection{Waste Packaging}

CH-TRU waste containers will be transported and received in a U.S. Nuclear Regulatory Commission (NRC)-certified TRUPACT-II shipping container. The CH-TRU waste packaging will include 55-gallon drums, Standard Waste Boxes (SWBs), and Ten Drum Overpacks (TDOs) [Nuclear Packaging, Inc., 1992]. The SWB is an oblong steel box that is $37 \mathrm{in.}$ high, 54.25 in. wide, and 71 in. long. The TDO is a welded-steel right circular cylinder 74 in. in diameter and 74 in. high.

RH-TRU wastes will be received at WIPP in NRC-certified type B shipping containers. One canister, which holds approximately three 55-gallon drum equivalents of waste, will be emplaced into each borehole. Each RH-TRU canister is made of 0.25 -inch-thick carbon steel, is $121 \mathrm{in}$. long and 26 in. in diameter. Appendix A includes a description of the RH-TRU canister to be used for disposal. The waste container requirements for WIPP are described in the WIPP Waste Acceptance Criteria (WAC) [DOE, 1991].

\subsection{TRU Waste Inventory}

The Waste Isolation Pilot Plant Transuranic Waste Baseline Inventory Report' (WTWBIR) [DOE, 1995e] data gives inventory quantities and waste material parameters for TRU waste. These data, as well as the radionuclide inventory, are supplied by the DOE waste generator/storage sites. Summaries of the radionuclide and non-radionuclide inventories were obtained from the WTWBIR and will be used in the PA process.

1 This document is available to interested readers by sending a request to U.S. Department of Energy, Carlsbad Area Office, 101 West Greene Street, Carlsbad, New Mexico 88220. 
The' radionuclide inventories of both CH-TRU and RH-TRU wastes are determined using (1) nondestructive assay, (2) some destructive analyses (to detect isotopes that do not lend themselves to nondestructive analyses or to evaluate waste streams that cannot be effectively analyzed through nondestructive methods), and (3) on-site accountability and tracking records of special nuclear materials, which record any changes of isotopic ratios during processing [DOE, 1995e].

The WTWBIR provides descriptions for the waste material parameters in TRU waste. The waste material parameters that have been identified by PA as being potentially significant to WIPP performance are as follows:

- Iron-base metal/alloys, aluminum-base metal/alloys, other metals, and other inorganics.

- Cellulose, rubber, and plastic.

- Solidified inorganic and organic waste.

- Soils.

- Container Materials: Steel, plastic liners, lead, and steel plug. 


\subsection{COMPARISON OF CONTACT-HANDLED AND REMOTE-HANDLED}

\section{TRANSURANIC WASTES}

The purpose of this chapter is to assess the similarities and differences between CH-TRU and RH-TRU wastes with respect to the LWA issues. However, this chapter does not compare the impacts of such waste on performance assessment. The initial step in identification of similarities and differences between CH-TRU and RH-TRU waste in the repository is to describe the inventory of each type of waste. By agreement with the State of New Mexico, no more than 250,000 $\mathrm{ft}^{3}$ $\left(7,080 \mathrm{~m}^{3}\right)$ of RH-TRU waste may be disposed at WIPP [DOE and State of New Mexico, 1981]. This is slightly less than 5 percent of the total WIPP design capacity. The remaining 95 percent of the waste at WIPP will be CH-TRU. The primary difference between CH-TRU and RH-TRU waste is that RH-TRU waste contains enough gamma-emitting isotopes with relatively short half-lives to produce a radiation dose rate greater than $200 \mathrm{mrem} / \mathrm{hr}$ at the external surface of the waste container. The CH-TRU and RH-TRU wastes considered in this study are consistent with the DOE Order 5820.2A definition of TRU waste. A summary comparing CH-TRU and RH-TRU waste classification criteria for the WIPP inventory wastes is given below.

\section{CH-TRU Wastes}

- Atomic number greater than 92

- Alpha emitters with half-lives greater than 20 years

- TRU radionuclide concentrations greater than $100 \mathrm{nCi} / \mathrm{g}$ of waste

- Maximum external radiation dose rate of $0.2 \mathrm{rem} / \mathrm{hr}(200 \mathrm{mrem} / \mathrm{hr})$

\section{RH-TRU Wastes}

- Atomic number greater than 92

- Alpha emitters with half-lives greater than 20 years

- TRU radionuclide concentrations greater than $100 \mathrm{nCi} / \mathrm{g}$ of waste

- External dose rate greater than $0.2 \mathrm{rem} / \mathrm{hr}(200 \mathrm{mrem} / \mathrm{hr})$ and less than or equal to $1,000 \mathrm{rem} / \mathrm{hr}^{2}$

- Relatively large quantity of beta- and gamma-emitting radionuclides with halflives typically 30 years or less

The Agreement for Consultation and Cooperation (C\&C Agreement) with the State of New Mexico [DOE and State of New Mexico, 1981] restricts RH canisters to less than or equal to 23 curies/liter

2. 1,000 rem is a WIPP WAC, Revision 4, requirement and has been made a statutory requirement in the LWA. 
maximum activity (averaged over the volume of the canister). This limitation is also a statutory limitation in the LWA.

In the Final Environmental Impact Statement, Waste Isolation Pilot Plant [DOE, 1980], the DOE specified a maximum dose rate of $100 \mathrm{rem} / \mathrm{hr}$, which included both CH-TRU and RH-TRU waste forms. To accommodate the higher dose rates that are characteristic of a portion of the RH-TRU inventory, the LWA included a provision (as derived from the C\&C Agreement) to allow up to $12,500 \mathrm{ft}^{3}\left(354 \mathrm{~m}^{3}\right)$ of RH-TRU wastes with limited dose rates of between 100 and $1,000 \mathrm{rem} / \mathrm{hr}$. Restrictions are imposed on the total quantity of TRU waste to 6.2 million $\mathrm{ft}^{3}\left(\sim 176,000 \mathrm{~m}^{3}\right)$ [Public Law 102-579, 1992] and total RH curies to 5.1 million curies [DOE and State of New Mexico, 1981].

The components of the TRU wastes to be regulated under the Resource Conservation and Recovery Act (RCRA) are anticipated to be very similar for CH-TRU and RH-TRU wastes. Hazardous constituents represented by EPA codes (codes assigned by EPA for each regulated hazardous waste) reported in the WTWBIR for the CH-TRU and RH-TRU inventories indicate that the CH-TRU hazardous waste constituents are inclusive of all the RH-TRU hazardous constituents [DOE, 1995e]. Treatment and processing programs are currently being developed by several of the generator/storage sites, which may also reduce the quantities of RCRA constituents in the RH-TRU inventory to be shipped to WIPP. The No-Migration Variance Petition currently being developed for disposal operations at the WIPP will further address the RCRA-regulated constituents of the RH-TRU inventory for the long-term period of performance.

CH-TRU and RH-TRU wastes are compared in two ways: (1) assessment of the waste form as received at WIPP during the disposal period pursuant to the waste acceptance criteria [DOE, 1991], and (2) assessment of the waste form under repository conditions as considered in the PA.

Data for comparison of the waste forms in the "as-received" condition are based on waste characterization information from the WTWBIR [DOE, 1995e]. The WTWBIR defines the waste inventory descriptions for CH-TRU and RH-TRU wastes for characteristics identified as potentially significant to PA. This information is discussed in section 3.1.1. 
The second comparison assessment evaluates CH-TRU and RH-TRU wastes in the repository environment. The long-term behavior of each waste type can vary from the "as-received" condition due to chemical, biological, or radiological changes. This comparison is discussed in section 3.2 .

\section{1 "As-Received" Inventory Description and Comparison}

This section provides a comparison of the CH-TRU and RH-TRU inventories in the form that these wastes will be received at WIPP (the "as-received" inventory). The primary governing documents are the WTWBIR and the WIPP WAC [DOE, 1995e; DOE, 1991]. Although sections of the WIPP WAC were meant to apply to activities planned in the WIPP Test Phase, the criteria throughout the WAC are applicable to both CH-TRU and RH-TRU waste in this study.

The three LWA issues applicable to "as-received" conditions are gas generation, flammability, and explosiveness because they apply to conditions prior to emplacement in the repository. These conditions and processes, as well as the "as-received" radionuclide inventory, are described below.

\section{Gas Generation in "As-Received" Waste}

All TRU containers received at WIPP are required to be vented to avoid gas buildup in the containers. The CH-TRU waste container venting requirements are defined in the WIPP WAC. The WAC states, "All waste containers, including any overpacks, shall be vented with filters . . . The minimum number of filters shall be one per drum, two per overpacked experimental bin in a Standard Waste Box (SWB), and two per SWB." The WAC also states: "Any rigid drum liners used in the waste containers shall be filtered or punctured ..." [DOE, 1991, p. 3-51].

An additional WAC requirement for $\mathrm{CH}-\mathrm{TRU}$ waste is: "Any confinement layers . . . used in the waste containers shall be closed only by a twist and tape or fold and tape closure." [DOE, 1991, p. 3-51] This requirement precludes waste generators from using a heat-seal method for closing plastic bags containing TRU waste. A heat-sealed bag could potentially trap gas, whereas the taping method allows gas to dissipate. 
The RH venting requirements are defined in the Remote-Handled Transuranic Waste Authorized Methods of Payload Control (RH-TRAMPAC) document, which is presented in Appendix 1.3.7 of the Safety Analysis Report (SAR) for the Remote-Handled Transuranic (RH-TRU) Waste Shipping Cask (Model NuPac 72-B) [VECTRA Technologies, Inc., 1994]. This document states: "Each Payload Container (RH-TRU Waste Canister) and any sealed containers (greater than 1 gallon in size) overpacked in a payload container to be transported in the 72-B Cask shall have one or more filter vents." [DOE, 1991, p. 3-51]

Because the CH-TRU and RH-TRU containers will be vented, most gas generated in the containers after receipt at WIPP is anticipated to dissipate. DOE will initially conduct headspace analysis as required for $\mathrm{CH}$-TRU and RH-TRU waste to be shipped to WIPP. These analyses will confirm gas generation conclusions in stored containers [DOE, 1995f].

\section{Flammability in "As-Received" Waste}

In addition to requiring vented containers, the WIPP WAC does not allow free liquids in the waste containers. Section 3.3.2 of the WAC states the following for CH-TRU and RH-TRU waste:

\footnotetext{
"Liquid waste will not be emplaced in the WIPP. TRU waste for emplacement in the WIPP shall contain as little residual liquid as is reasonably achievable. All internal containers (e.g., bottles, cans, etc.) must be well-drained, but may contain residual liquids. As a guideline, residual liquid in well-drained containers will be restricted to approximately one percent of the volume of the internal container. In no case shall the total liquid equal or exceed one volume percent of the waste container (e.g., drum, SWB, or RH-TRU waste canister)."
}

Since there will not be significant quantities of liquids in the containers, there will be minimal hydrogen gas generated from alpha radiolysis of residual water (see section 3.2.1) and therefore no flammability concerns relating to water degradation. 
Microbial degradation and alpha radiolysis of cellulose, rubber, and plastic are other mechanisms for hydrogen gas generation in "as-received" waste. These mechanisms have been evaluated as part of the transportation studies for CH-TRU and RH-TRU wastes. Because heat is associated with radiolysis, the thermal output (as measured in watts) of the waste containers is restricted [Nuclear Packaging, Inc., 1992; VECTRA Technologies, Inc., 1994]. However, very little heat is expected to be associated with TRU waste since the average RH-TRU waste heat output has been estimated at less than 1 watt for the current inventory projections.

The Department of Energy Waste Isolation Pilot Plant: Notice of Final No-Migration Determination (NMD) [EPA, 1990] requires that no container be placed in WIPP "if it contains flammable mixtures of gases in any layer of confinement, or mixtures of gases that could become flammable when mixed with air. To assure a sufficient margin of safety, EPA defines any mixture as potentially flammable if it exceeds 50 percent of the lower explosive limit (LEL) of the mixture in air." To ensure that this flammability restriction would be met during the proposed test phase, the NMD required headspace sampling of the void space of each waste container for hydrogen, methane, and volatile organic compounds (VOCs). If a container shows significant levels of flammable VOCs, sites must perform tests to determine if a flammable mixture can be formed with the air, or the waste must be treated to reduce the flammable concentrations.

The Transuranic Waste Characterization Quality Assurance Program Plan (QAPP) [DOE, 1995f] precludes emplacement of containers that may generate flammable gases. The QAPP requires that sites implement testing processes (headspace analyses) for waste that will be sent to WIPP. No container to be emplaced in WIPP may exceed 50 percent of the lower explosive limit in any layer of confinement for hydrogen and methane when potentially flammable VOCs as a class are greater than $500 \mathrm{ppm}$. This requirement will be applicable until DOE demonstrates that waste packages do not contain high concentrations of flammable gases. Although the NMD requirements have been developed by EPA for DOE's test program, headspace sampling is expected to remain a requirement for a statistical portion of the waste sent to WIPP for disposal.

Flammability is not a concern for "as-received" CH-TRU and RH-TRU wastes. There will be minimal residual water available from which alpha radiolysis can generate gas. The $\mathrm{CH}-\mathrm{TRU}$ and 
RH-TRU safety analysis report restricts the wattage of the wastes to minimize packages that generate gas due to radiolysis of cellulose, rubber, and plastic. There are restrictions for flammable gases allowed to be packaged in the waste container pursuant to the NMD. CH-TRU and RH-TRU containers are required to be vented for an additional margin of safety. There is no significant difference between CH-TRU and RH-TRU waste in this respect.

\section{Explosiveness in "As-Received" Waste}

The WIPP WAC, Section 3.3.4, prohibits packaging explosives and compressed gases in TRU waste containers to be shipped to WIPP. The WAC requirement is stated as follows for CH-TRU and RH-TRU waste: "Transuranic waste shall contain no explosives or compressed gases. 49 CFR 173 Subpart C ... defines explosives and 49 CFR Part 173 Subpart $G$ defines compressed gases." [DOE, 1991, p. 3-29]. Additionally, DOE has conducted a chemical compatibility assessment of CH-TRU and RH-TRU wastes to ensure that a reaction will not occur as a result of incompatible waste [Nuclear Packaging, Inc., 1992; VECTRA Technologies, Inc., 1994].

Because of the WAC restriction on packaging explosives and compressed gas for shipment to WIPP and those discussed in the Flammability section, explosive gases will not accumulate in the waste containers. Since a buildup of explosive gas or the packaging of explosives in the waste will not occur, the potential for an explosive environment in "as-received" waste at WIPP is not a concern. There is no significant difference between CH-TRU and RH-TRU waste in this respect.

\subsubsection{TRU Waste Inventory}

The estimated TRU waste disposal inventory for WIPP, as defined in the WTWBIR, is presented in Table 3-1. This table compares the volumes of CH-TRU and RH-TRU wastes, grouped into final waste forms [DOE, 1995e]. 
Table 3-1. Estimated Transuranic Waste Disposal Inventory for WIPP [Source: DOE, 1995e]

\begin{tabular}{|l|c|c|c|c|c|}
\hline \multicolumn{1}{|c|}{ Final Waste Form } & $\begin{array}{c}\text { CH Waste } \\
\left(1000 \mathbf{m}^{3}\right)\end{array}$ & $\begin{array}{c}\% \\
\text { Total CH } \\
\text { Inventory }\end{array}$ & $\begin{array}{c}\text { RH W aste } \\
\left(1000 \mathbf{m}^{3}\right)\end{array}$ & $\begin{array}{c}\text { \% } \\
\text { Total RH } \\
\text { Inventory }\end{array}$ & $\begin{array}{c}\text { \% Total in WIPP } \\
\text { TRU Inventory }\end{array}$ \\
\hline Combustible & 62 & 34 & 0.02 & $<1$ & 33 \\
\hline Filter & 2.6 & 1.4 & 0.0043 & $<1$ & 2 \\
\hline Graphite & 0.76 & $<1$ & 0 & 0 & 1 \\
\hline Heterogeneous Waste & 39 & 22 & 5.9 & 83 & 24 \\
\hline Inorganic Non-Metal Waste & 1.8 & 1 & 0 & 0 & 1 \\
\hline Lead/Cadmium Metal Waste & 0.31 & $<1$ & 0.0098 & $<1$ & $<1$ \\
\hline Salt Waste & 0.15 & $<1$ & 0.0046 & $<1$ & $<1$ \\
\hline Soil & 1.3 & 1 & 0 & 0 & 1 \\
\hline Solidified Inorganics & 34 & 19 & 0.90 & 13 & 19 \\
\hline Solidified Organics & 2.1 & 1 & 0 & 0 & 1 \\
\hline Uncategorized Metals & 30 & 17 & 0.23 & 3 & 16 \\
\hline Unknown' & 1.7 & 1 & 0.035 & 1 & 1 \\
\hline \hline Total & 180 & & & & \\
\hline
\end{tabular}

1 Includes all metals/alloys except lead and cadmium.

2 Waste is presently uncharacterized but will be characterized prior to shipment to WIPP.

In addition to showing the estimated disposal volume of each CH-TRU and RH-TRU final waste form, Table 3-1 shows the percentage that the final waste forms contribute to the CH-TRU, RH-TRU, and total TRU waste inventories. As can be seen in Table 3-1, the majority of the CH-TRU inventory is made up of combustibles, heterogeneous waste, metals, and solidified inorganics. The RH-TRU waste inventory is comprised primarily of heterogenous waste, solidified inorganics, and metals. In the RH-TRU inventories, generator/storage sites generally include the combustible waste in the heterogeneous waste category. Heterogeneous waste is a category that includes metal, inorganic non-metal, or combustible waste but is not dominant in any one of these types of waste. Combining the combustible and heterogeneous $\mathrm{CH}$-TRU waste gives a more accurate comparison of the CH-TRU and RH-TRU inventories and shows that CH-TRU and RH-TRU waste volume percentages are similar. Since RH-TRU waste is only 5 percent by volume of the WIPP 
inventory, the last column of Table 3-1 shows that RH-TRU waste has very little contribution to the final waste forms in the entire WIPP TRU waste inventory.

In addition to the volumes of waste provided in Table 3-1, the WTWBIR also provides the densities (which can be converted to mass) for the TRU waste packaging materials [DOE, 1995e]. Conversion to mass provides for the measurement and comparison of materials on a total-quantity basis. The lead and steel in the RH canister and the steel in the RH shield plug make up almost 90 percent (by mass) of the RH-TRU inventory and 14 percent (by mass) of the total WIPP inventory. The steel in the CH-TRU packaging makes up 19 percent (by mass) of the CH-TRU inventory and 16 percent (by mass) of the total WIPP inventory. Because the amount of lead and steel associated with TRU waste packaging is included in the WTWBIR, it will be included in the evaluation of the long-term performance of the repository.

Many of the CH-TRU and RH-TRU waste streams are generated from similar processes and consist of similar waste materials with different concentrations of radionuclides. For example,san Oak Ridge National Laboratory (ORNL) waste stream for contaminated equipment, decontamination debris, or dry solids can be CH-TRU or RH-TRU waste; and in the WTWBIR, these streams contain identical densities for the waste material parameters. Only the radionuclide concentrations are different. Several of the Richland (Hanford) site waste stream descriptions and waste material parameter densities for two waste streams (one $\mathrm{CH}$, the other $\mathrm{RH}$ ) are identical, with the exception of the radionuclide concentrations [DOE, 1995e].

The TRU waste streams from the generator sites have been characterized in several ways, including process knowledge (review of available waste records and documentation), as well as sampling and analysis. The majority of RH-TRU waste is projected to come from ORNL and Hanford. DOE plans to process wastes not currently in conformance with WAC requirements in facilities such as the proposed Waste Handling and Packaging Plant (WHPP) at ORNL. Examples of procedures that might be used to process these wastes include evaporation, vitrification, and stabilization to immobilize radionuclides. 
One conclusion of this document can be derived by examining Table 3-1. Table 3-1 shows that the final waste forms to be sent to WIPP are similar for CH-TRU and RH-TRU wastes. The table shows the percentages of each inventory relative to the final waste forms to be shipped to WIPP pursuant to the WTWBIR. This table indicates that each inventory includes similar types of materials in various quantities.

\subsubsection{TRU Radionuclide Inventory}

The WTWBIR was used to provide the TRU radionuclide inventories for this study. The initial activities for the radionuclides in both the CH-TRU and RH-TRU waste inventories are listed in Appendix B and have been normalized via activity decay estimates to December 1993. The RH-TRU radionuclide inventory in Appendix $B$ was used to estimate an initial average heat output of less than $1 \mathrm{~W}$ per canister, much less than the $300 \mathrm{~W}$ allowed by the WIPP WAC. A 300 W heat output corresponds to a formation temperature increase of less than $10^{\circ} \mathrm{C}$ [Molecke et al., 1993]. Therefore, a $1 \mathrm{~W}$ heat output is expected to cause a negligible temperature increase. The decay series for the CH-TRU and RH-TRU radionuclides considered in PA are shown in Appendix C. The WTWBIR indicates that Cesium-137 (Cs) and Strontium-90 (Sr) are the sources of most of the penetrating radiation. It is for this reason that $\mathrm{Cs}$ and $\mathrm{Sr}$ have been highlighted for comparison.

The activity for each radionuclide listed in Appendix B was calculated using the decay model ORIGEN2 over the period of zero to 10,000 years. Results of these calculations and an explanation of the ORIGEN2 calculation are presented in Appendix C.

Using the results presented in Appendix C, a plot was constructed to demonstrate that the activity of radionuclides in RH-TRU waste decreases to a small percentage of the total activity of the TRU inventory early in the post-closure period. Figure 3-1 shows the percent of the activity that is associated with RH-TRU waste versus time for up to 1,000 years. This figure demonstrates that the activity contribution of RH-TRU radionuclides to the total radioactivity in the repository decreases rapidly in slightly over 200 years from about 36 percent to 1 percent and then a very small increase begins after 300 years because of ingrowth from the decay of other radionuclides. 


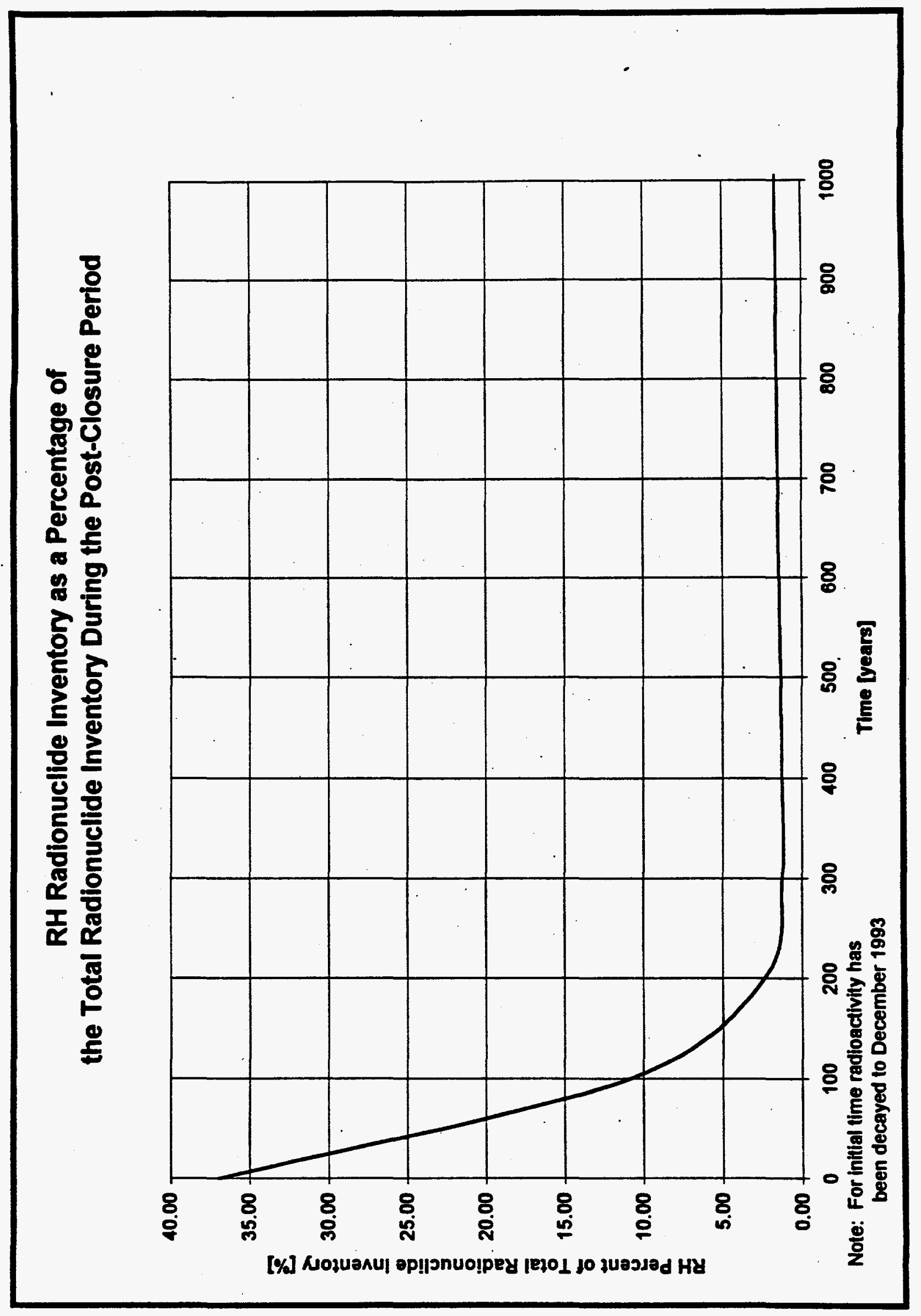

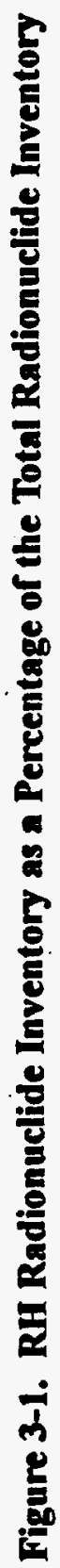


Important conclusions can be drawn from the information presented in Figure 3-1. These conclusions include the following:

- The major radionuclides (Sr-90 and Cs-137) in RH-TRU waste decrease rapidly.

- The contribution of RH-TRU waste to the total radionuclide inventory in the repository will decrease from about 36 percent to 1 percent in slightly more than 200 years after repository closure.

- RH-TRU waste will contain less specific radioactivity than CH-TRU waste after 200 years because the RH-TRU radionuclide inventory will represent less than 5 percent of the total TRU radionuclide inventory.

Therefore, RH-TRU waste has an effect on the repository for only a short portion of the 10,000-year period of regulatory concern.

\subsection{Comparison of LWA Issues During the Post-Closure Period}

The next four subsections address the issues specified in the LWA for comparing CH-TRU and RH-TRU waste forms. The comparison of TRU wastes in these subsections considers the expected repository conditions and consequent behavior of the waste forms during the post-closure period of 10,000 years.

\subsubsection{Gas Generation}

The evaluation of gas generation from TRU waste is a necessary component in the comparison of CH-TRU and RH-TRU wastes because gas has the potential to directly affect the long-term performance of the repository. Because gas cannot transport significant quantities of radionuclides, brine is considered the primary transporting medium to be evaluated for both disturbed and undisturbed repository scenarios.

The dominant gas generation processes expected to occur in the WIPP repository include (1) corrosion of iron and aluminum alloys; (2) microbial degradation of cellulose, and perhaps rubber 
and plastic; and (3) alpha radiolysis of brine and residual water in the waste as well as alpha radiolysis of cellulose, rubber, and plastic. Gas generation is synergistically dependent on the conditions within the repository, with particular emphasis on the residual water content in waste at the time of emplacement and brine inflow from the surrounding formation. Laboratory gas generation studies have shown that the quantity of brine in the repository has a direct effect on the gas generation rates [Brush, 1995].

\section{Gas Generation Mechanisms}

From the standpoint of gas generation for the WIPP repository, the most important mechanisms are corrosion (specifically anoxic corrosion) of steels and other iron alloys, as well as aluminum alloys and microbial degradation (specifically anaerobic microbial degradation) of cellulosics, rubber, and plastic. Gas generation from alpha radiolysis is not as important as anoxic corrosion and anaerobic microbial degradation because results from radiolysis studies indicate that gas generation rates from alpha radiolysis are substantially lower than rates from anoxic corrosion and anaerobic microbial degradation [Brush et al., 1993]. A general discussion of the gas generation mechanisms is provided below. Detailed discussions of these complex mechanisms as they apply to this study can be found in Appendix D.

\section{Corrosion}

Anoxic corrosion of iron and aluminum alloys in TRU waste has the potential to consume water and produce hydrogen, assuming several repository conditions are present [Brush, 1995]. The primary conditions that must be satisfied for anoxic corrosion to occur are (1) sufficient quantities of brine from the surrounding Salado Formation enter the WIPP disposal rooms after closure and/or (2) initial water in the waste is available. Gas generation rates from anoxic corrosion for CH-TRU and RH-TRU wastes are similar because there are no significant differences between these waste forms that would directly influence corrosion.

RH-TRU corrodible metals (i.e., RH-TRU iron, aluminum, and waste packaging) will contribute 6 percent by mass without the shield plug and 31 percent by mass with the shield plug to the total 
corrodible metal content (i.e., all TRU iron, aluminum, and waste packaging) of the repository [DOE, 1995e]. However, if sufficient brine is available, microbial degradation will produce carbon dioxide and/or hydrogen sulfide (in addition to other gases) that could potentially passivate steels and other iron-base alloys and thus prevent additional hydrogen production and water consumption from anoxic corrosion of these waste metals. Further, small amounts of brine could initiate anoxic corrosion, which will produce hydrogen, consume water, increase the pressure, and perhaps slow or prevent additional brine inflow or even cause brine outflow, thus impeding additional anoxic corrosion and hydrogen generation. Thus, the availability of water in the WIPP repository may limit anoxic corrosion and therefore hydrogen generation, regardless of the quantity of $\mathrm{CH}-\mathrm{TRU}$ and RH-TRU steels and other iron-base alloys and packaging materials included in the WIPP inventory [Brush, 1995]. The DOE is also currently evaluating alternatives for the RH-TRU shield plug, which could lower the mass contributed by RH-TRU corrodible metals from 31 percent to 6 percent of the total corrodible inventory.

The comparison of CH-TRU and RH-TRU corrodible metal waste indicates that RH-TRU iron-base alloys, aluminum-base alloys, and the waste packaging materials could contribute from zero to 31 percent to the total gas from corrodible metal waste (i.e., amount of gas from all TRU corrodible metal waste and packaging materials) in the WIPP repository. The range of RH-TRU gas generation potential from corrodible metals will be dependent on the amount of brine present and the passivation of steels and other iron-base alloys from microbial degradation products. To obtain the lower end of nearly zero percent gas generation from RH-TRU metal waste, the amount of brine would be severely limited to the extent that no TRU metal waste would corrode. To reach the higher extreme of 31 percent, sufficient brine must be available to react with all CH-TRU and RH-TRU corrodible metal wastes, and passivation of the steels and other iron-base alloys must not occur. Therefore, depending on the total amount of brine present and the potential for the passivation of the steels and other iron-base alloys, 6 percent (with the exclusion of the RH-TRU shield plug) or up to 31 percent (with the inclusion of the RH-TRU shield plug) of the total gas from corrodible metal waste could be generated from the RH-TRU corrodible metal waste inventory. 


\section{Microbial Degradation}

Anaerobic microbial degradation of cellulosics, rubbers, and plastics in the TRU waste has the potential to produce a variety of gases (carbon dioxide and/or hydrogen sulfide in addition to other gases), assuming several repository conditions are present. One of the primary conditions for the generation of gases from anaerobic microbial degradation is the presence of sufficient quantities of brine or water vapor for diffusive transport from the waste or rock in which the microbes occur [Brush, 1995]. Estimates of microbial gas production are dependent on how much microorganisms will degrade cellulosics, rubbers, and plastics in the waste that is to be emplaced in the WIPP [Brush et al., 1991]. Gas generation rates from anaerobic microbial degradation for CH-TRU and RH-TRU wastes are similar because there are no distinguishing attributes of these waste forms that would directly influence anaerobic microbial degradation.

The comparison of CH-TRU and RH-TRU organic wastes indicates that the inclusion of RH-TRU cellulosic, rubber, and plastic wastes in the WIPP repository could contribute approximately 1 percent by mass to the total organic content (i.e., all TRU cellulose, rubber, and plastic) of the WIPP repository [DOE, 1995e], therefore contributing from zero to 1 percent of the total gases from all TRU organic waste materials in the WIPP repository. To reach the 1 percent, sufficient brine must be available to interact with all CH-TRU and RH-TRU organic waste. Therefore, depending on the total amount of brine present, up to 1 percent of the total gas generated from all TRU organic waste could be produced from the RH-TRU organic waste inventory.

\section{Radiolysis}

Radiolysis by alpha particles is not expected to be a significant mechanism for gas generation in the WIPP repository [Brush, 1995]. Alpha radiolysis of the water in the waste and brine could consume water and brine, producing hydrogen and oxygen. A variety of gases can also be produced by the alpha radiolysis of cellulosics, rubbers, and plastics in the waste [Molecke, 1979]. Conclusions from experiments conducted at Argonne National Laboratory-East indicate that alpha radiolysis of WIPP brines will produce hydrogen and oxygen at rates much lower than the expected gas production rates for anoxic corrosion and anaerobic microbial degradation [Brush et al., 1993]. Additional evaluation 
of alpha radiolysis at Sandia National Laboratories suggests that gas generation from alpha radiolysis of cellulosics, rubbers, and plastics will be minimal from the standpoint of long-term gas production in the WIPP repository [Brush, 1995]. Further, because molecular dissociation caused by beta and gamma radiation will be insignificant in a repository for TRU waste [Brush, 1995], these types of radiation have not been considered in this evaluation of gas generation. In consideration of the $\mathrm{CH}-\mathrm{TRU}$ and RH-TRU waste inventory, the amounts of gas generated from alpha radiolysis is anticipated to be minimal. Therefore, based on the estimated production of gas from alpha radiolysis that could occur in the WIPP disposal rooms, alpha radiolysis from RH-TRU waste will be a minor contributor to the production of gas from all TRU waste.

Evaluation of the primary gas generation mechanisms indicates that the brine available in the disposal environment is the determining factor relative to the quantity of gas generated during the compliance period. The amount of corrodible metals and organic materials present in the TRU waste inventory indicates a high probability of gas generation in the WIPP disposal rooms, provided there is sufficient brine available. The amount of gas generated from RH-TRU corrodible and organic waste forms in the WIPP repository can range from approximately zero to 31 percent of the total gases generated from TRU waste. Only about zero to 1 percent of this gas can be attributed to organic wastes. The zero to 31 percent range could be significantly narrowed to about 6 percent if a shield plug made from a non-corrodible material were used as an alternate. In addition, the amount of gas generated from RH-TRU waste is expected to be smaller because of the small amount of RH-TRU organic waste, the limited time frame in which anoxic corrosion is likely to occur, and the potential passivation of iron-base metals due to microbial degradation.

\subsubsection{Flammability and Explosiveness}

The term "flammable" can be defined as the ability of a material to generate a sufficient concentration of combustible vapors to be ignited and produce a flame. An explosion of gases, on the other hand, is simply the very rapid combustion of flammable vapors. An explosion typically occurs when flammable gases are ignited in a confined space and pressure cannot freely dissipate. The terms flammability and explosiveness can be considered synonymous for purposes of this study. 
The.U.S. Department of Transportation (DOT) defines a gas as being flammable if, when mixed with air at a concentration at or below 13 percent by volume, it forms a flammable mixture, or its flammable range in air is wider than 12 percent regardless of the lower limit [49 CFR Part 173]. The flammable range is defined as where combustion is possible for a given gas mixture if a credible ignition source exists. This range is the same for both the flammability and explosiveness potential of a given gas mixture. Combustion can occur in this range because the optimal fuel-to-air (flammability) ratio exists (expressed as a percentage of fuel in air) to allow for ignition and sustained combustion.

The lowest concentration of fuel in the flammable range is termed the Lower Explosive Limit (LEL). Concentrations less than the LEL are not flammable because there is too little fuel. The highest ratio that is flammable is the Upper Explosive Limit (UEL). Concentrations greater than the UEL are not flammable because there is too much fuel displacing oxygen (resulting in too little oxygen). Fuel concentrations between the LEL and UEL are optimal for starting and sustaining combustion.

For a flammable gas to be ignited, three conditions must be met. The flammable gas must be present in flammable concentrations, an oxidant such as oxygen must be present (the repository is expected to be anoxic shortly after closure), and a source of ignition must be available. For this study, the availability of an ignition source is not being evaluated.

There is a potential for the collection of flammable mixtures of hydrogen, methane, and oxygen in the room headspace above the waste during the post-closure period [Slezak and Lappin, 1990]. The primary source of flammable gas in the repository will be from corrosion of iron- and aluminum-based metals and microbial degradation of cellulose, rubber, and plastic in the waste and waste containers (see section 3.2.1). Alpha radiolysis is expected to be a minor contributor to gas generation (see section 3.2.1).

The waste material parameters in TRU waste that generate gas as they corrode or degrade include primarily iron, aluminum, cellulose, rubber, and plastic. The steel in waste packages and shield plugs can also contribute to flammable gas generation. A side-by-side comparison reveals that the gas generating waste material parameters and packaging materials in RH-TRU waste could contribute 
only a minor portion of the total flammable gas potential compared to $\mathrm{CH}$-TRU waste. This conclusion can be derived by examining the percentages by mass for the gas generating waste material parameters and packaging from the total TRU waste inventory for both CH-TRU and RH-TRU wastes. These percentages are presented in Table 3-2.

The waste material parameters and packaging materials can be collectively grouped into a category called gas generation materials. This category can then be normalized to the total of gas generation materials in the entire TRU inventory for WIPP to give an estimate of how much the CH-TRU and RH-TRU inventories individually contribute to the flammable gas potential. Table 3-2 shows that when the shield plug is included in this estimate, the CH-TRU and RH-TRU inventories contribute 87 and 13 percent, respectively. If the shield plug is not included, then the results are 94 and 6 percent, respectively.

Table 3-2. Waste Material Parameters and Packaging that Contribute to Flammable Gas Generation (as a Percentage of Mass)

\begin{tabular}{|c|c|c|}
\hline Waste Materia Parameter. & $\% 6$ rom $0 \mathrm{I}$ & $\%$ rrom RH \\
\hline Iron & 96 & 4 \\
\hline Aluminum & 94 & 6 \\
\hline Cellulose, Rubber, and Plastic & 99 & 1 \\
\hline Waste Packaging Materials? & \% Irom CH & $\%$ trom RH \\
\hline Containers and Shield Plug & 58 & 42 \\
\hline Containers Excluding Shield Plug & 88 & 12 \\
\hline Collected Gas Generation Materiais & $\%$ irom oH & $\%$ from RH \\
\hline Including Shield Plug & 87 & 13 \\
\hline Excluding Shield Plug & 94 & 6 \\
\hline
\end{tabular}

1 Iron and steel included only. Source: DOE; 1995e.

RH-TRU waste is not unique compared to CH-TRU waste in terms of its potential to generate flammable gas because both inventories consist of similar gas generating materials. The quantities 
of these materials in RH-TRU waste, however, are much less than that for CH-TRU waste. Therefore, it can be concluded that the RH-TRU waste inventory will have only a small contribution to the total flammability and explosiveness potential in the repository.

\subsubsection{Solubility}

The solubility of radionuclides in TRU wastes determines their potential mobility as solutes in WIPP brines. The mobilized radionuclides, for the purposes of transport modeling, are called the radionuclide source term. The most reasonable mechanism for potential release of radionuclides to the accessible environment is dissolution in brine followed by some means of transport. The mobile concentrations that may potentially leave the repository are a key factor in the determination of compliance with 40 CFR Part 191.

There are several major parameters that influence the amount of radionuclides dissolved in the WIPP brine [Novak et al., 1995]. These parameters.include:

- Brine chemical composition, $\mathrm{pH}$, and temperature.

- Complex formation of radionuclide species dissolved in the aqueous phase.

- The WIPP radionuclide inventory.

The radionuclide solubilities for CH-TRU and RH-TRU wastes will be the same because the parameters mentioned above, which directly influence the solubility, will not be unique to either CH-TRU or RH-TRU waste forms. Therefore, the difference in the potential inventory concentration of radionuclides relative to $\mathrm{CH}$ and $\mathrm{RH}$ is dependent on the increased quantity of certain radionuclides present in the RH-TRU wastes. Since strontium and cesium are initially present in RH-TRU in quantities greater than in CH-TRU waste, the determination of the influence of RH-TRU on the potential inventory concentration is governed by the availability of $\mathrm{Sr}$ and $\mathrm{Cs}$.

For the major radionuclides in the CH-TRU and RH-TRU inventory, the potential for these radionuclides to cross the regulatory boundary and reach the accessible environment will be controlled by the degree to which they can become soluble in WIPP brines, which is the transport 
mechanism, and by the degree to which the radionuclides are retarded during transport. There must be interaction of the brine and the radionuclide source terms in order for transport of the radionuclides to potentially occur.

The extent to which radionuclides become dissolved in WIPP brine will be limited by two significant factors:

1. The current configuration for the disposal of RH-TRU wastes in WIPP involves emplacement in steel canisters horizontally in the rooms and drifts. These canisters will hold three 55-gallon drum equivalents of waste and will be fabricated out of 0.25 -inch-thick steel. The RH-TRU canister will provide a barrier to the transport of radionuclides because of the thickness of the containment vessel (i.e., longer corrosion time necessary for the brine to contact the actual waste forms) and the shield plug, which will provide temporary isolation from the disposal rooms.

2. The half-lives of $\mathrm{Sr}$ and $\mathrm{Cs}$ are about 30 years each, thereby limiting the period in which brine can significantly interact with these radionuclides to just over 200 years after repository closure. Even if a significant amount of brine were able to interact with the RH-TRU waste forms after 200 years, the $\mathrm{Sr}$ and $\mathrm{Cs}$ will have significantly decreased through natural decay processes and would not be present in substantial quantities after this period.

These expected outcomes lead to the conclusion that the chemical dissolution of radionuclides in the total expected brine volume will not be substantially altered by the presence of the RH-TRU waste inventory. After 200 years, the CH-TRU waste inventory will be the primary contributor to the radionuclide source term.

In conclusion, the RH-TRU waste inventory will not significantly add to the radionuclide source term of WIPP. This can be concluded from (1) the rapid decay of the $\mathrm{Sr}$ and $\mathrm{Cs}$ radionuclides initially present in the RH-TRU wastes are available for only a limited period of time for brine interaction; and (2) the RH-TRU waste package and configuration, which will limit brine accessibility to the waste during the period when $\mathrm{RH}$ radionuclides are present in high concentrations. 


\subsubsection{Brine and Geochemical Interactions}

The magnitude of the radiation dose rate at the surface of the waste packages is the primary characteristic that can affect brine and geochemical interactions with respect to comparing the similarities and differences between CH-TRU and RH-TRU wastes. Radiation at the surface of the waste packages will be a result of gamma emissions. The TRU waste to be emplaced in WIPP will emit three primary radiations: alpha, beta, and gamma. Only gamma radiation can penetrate the waste package and be absorbed by the surrounding formation, while alpha and beta radiation will be shielded by the waste contents and waste packaging. The result of absorbed radiation in the formation can be an alteration in the chemical structure of rocksalt as well as a heating of the formation.

The maximum surface dose rates allowed for WIPP waste packages are listed below:

\begin{tabular}{cc} 
Waste Type & Dose Rate (rem/hr) \\
\hline CH & 0.2 \\
RH-1 & 100 \\
RH-2 & 1,000
\end{tabular}

For gamma radiation, rem $/ \mathrm{hr}$ is approximately equivalent to $\mathrm{rad} / \mathrm{hr}$. RH-TRU waste has two maximum limit values because 95 percent of RH-TRU waste by volume cannot exceed $100 \mathrm{rem} / \mathrm{hr}$, while 5 percent is allowed to have up to $1,000 \mathrm{rem} / \mathrm{hr}$ [Public Law 102-579]. For purposes of this evaluation, these two categories have been referred to as RH Type 1 and Type 2, respectively.

Rocksalt is known to suffer radiation damage for absorbed doses in excess of $10^{4} \mathrm{rad}$ [Hull, 1987]. A result of this damage is an increase in the hardness, embrittlement, and cleaving characteristics of the rocksalt [Levy, 1983]. In addition, when dry gamma irradiated rocksalt is dissolved in water, hydrogen gas is released with a corresponding increase in the $\mathrm{pH}$ (alkalinity) of the aqueous solution [Jenks and Bopp, 1977; Panno and Soo, 1984]. When brine and rocksalt are irradiated together, the brine becomes more acidic, while the dissolution of the rocksalt produces a basic solution as is the case with dry irradiations [Panno and Soo, 1984]. When rocksalt is exposed to damaging doses of 
radiation, changes occur in its chemical structure. These changes take the form of induced defects within the lattice or crystalline structure of sodium chloride. These defects include the formation of F-centers, which are then followed by the formation of sodium metal colloids.

An F-center is a defect that causes rocksalt to become amber in color. This can occur when radiation energy causes a chloride ion to vacate its position in the lattice structure of sodium chloride. These vacant positions are then subsequently filled by free electrons that become trapped in these positions by electrostatic forces. F-center formation is known to occur for radiation doses exceeding $10^{4} \mathrm{rad}$ along with temperatures ranging from room temperature $\left(25^{\circ} \mathrm{C}\right)$ up to about $300^{\circ} \mathrm{C}$ [Levy, 1983 ; Hull, 1987].

Sodium metal colloids are formed as a result of F-center formation and cause the rocksalt to become purple-to-blue-to-black in color with increasing radiation dose [Jenks and Bopp, 1977]. The vacancies caused by the F-centers are filled with electrons that then combine with sodium metal ions to form the uncharged sodium atom. Since chloride ions have been displaced from their lattice positions, the sodium metal atoms tend to aggregate into colloids.

Besides radiation induced effects, heat can also have effects on brine and rocksalt geochemistry. Evaluations involving the heating of unirradiated rocksalt and its subsequent dissolution indicate that $\mathrm{pH}$ shifts similar to those for dry irradiated rocksalt occur for tested temperatures as low as $40^{\circ} \mathrm{C}$ [Panno and Soo, 1984]. In addition, rocksalt heated to high temperatures (about $190^{\circ} \mathrm{C}$ ) has resulted in the release of hydrogen chloride gas [Pederson, 1985]. Another possible effect of heat is its tendency to mobilize brine. Brine filled inclusions are known to migrate up a thermal gradient [Olander, 1984].

As mentioned earlier, absorbed gamma radiation doses of a magnitude in excess of $10^{4}$ rad are required to cause F-center formation and subsequent sodium metal colloid growth. If these defects occur, then the potential exists for localized $\mathrm{pH}$ shifts, which could result in a slight increase in the corrosivity and gas generation potential of the repository environment. Also, heating effects could contribute to the corrosivity of this environment. 
The genesis of such an environment could occur if sufficient brine were to become available in the near-field formation surrounding the waste packages. Under this condition, brine would migrate into the near-field formation because of a thermal gradient. The accumulation of brine would dissolve irradiated rocksalt, producing corrosive gases and a corresponding increase in brine $\mathrm{pH}$.

To evaluate whether the emplacement of CH-TRU and RH-TRU waste in WIPP will result in sufficient gamma radiation to generate defects, the analysis in Appendix $\mathrm{E}$ was conducted. From this analysis a plot of the average absorbed dose in ten half-thicknesses (one half-thickness is approximately 2 inches) for rocksalt as a function of time was estimated and is shown in Figure 3-2 for both CH-TRU and RH-TRU waste. The estimate is based on the maximum surface dose levels allowed for each type of waste as presented above. In addition, the radionuclide half-life for Cs-137 was used in the estimate since it is the most abundant gamma-emitting radionuclide in the WIPP TRU inventory:

As Figure 3-2 shows, the potential exists for the formation to receive absorbed dose levels in excess of $10^{4} \mathrm{rad}$ as a result of gamma radiation from both CH-TRU and RH-TRU wastes. Radiation levels of this magnitude would occur in about the first 100 years following waste disposal and could be sufficient to cause defects in the formation in the immediate vicinity of the waste packages. However, these dose levels are small compared to HLW.

Heat generated in the repository because of RH-TRU waste emplacement has been evaluated by SNL in nonradioactive in situ tests [Molecke et al., 1993]. These tests have demonstrated that at a maximum allowable heat output of $300 \mathrm{~W}$ a temperature rise of less than $10^{\circ} \mathrm{C}$ at the top of the borehole-air interface could be expected. This small temperature rise is insignificant compared to the high temperatures required to cause the release of hydrochloric gas and significant brine migration. CH-TRU waste is expected to cause negligible temperature rises in the surrounding formation [Sandia WIPP Project, 1992]. 


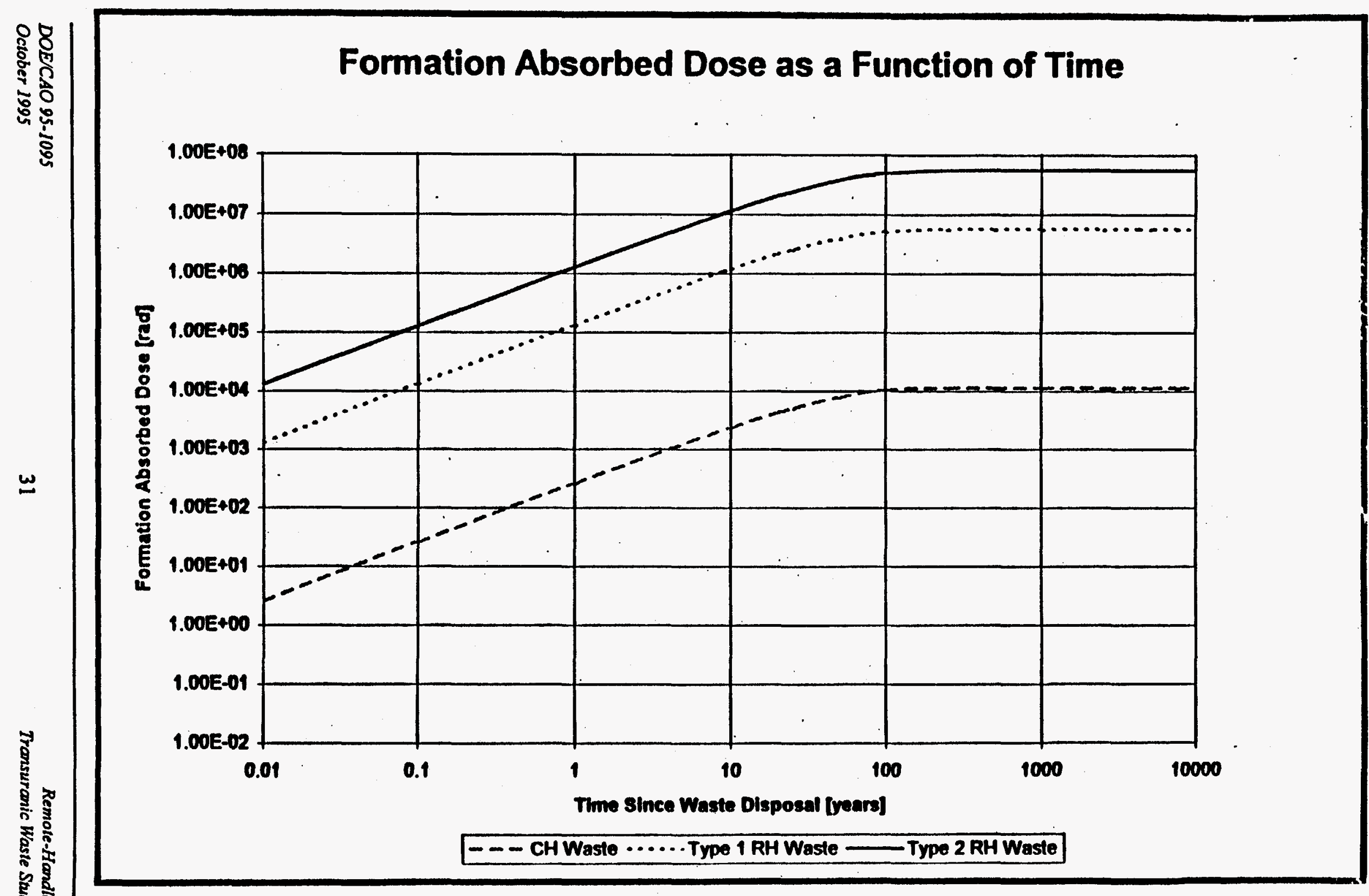

Figure 3-2. Formation Absorbed Dose as a Function of Time 
As indicated by the discussion above, both CH-TRU and RH-TRU waste could potentially deposit sufficient radiation in the formation to alter the chemical characteristics of the waste package environment. The degree to which this can occur is dependent on many uncertain factors, one of which is the proximity of the waste packages to the formation during the first 100 years after closure (after this period, dose rates are expected to be so low that little additional radiation and heat would be imparted to the formation), the presence of mineral impurities in rocksalt (impurities tend to suppress colloid growth [Levy, 1983]), the amount of brine available in the near-field formation, and the probability that waste packages are, and will be, packed to the maximum dose rates allowed.

In conclusion, the radiation from both CH-TRU and RH-TRU could have a small effect on brine and geochemical interactions in the WIPP disposal system. The result is a potential increase in the corrosivity of the waste package environment for both CH-TRU and RH-TRU wastes. The contribution of gas generated by this corrosion process is expected to be negligible compared to other corrosion processes because radiation doses will be relatively low, thus irradiating very little rocksalt. Further, the initial thermal gradient is expected to be small, resulting in little brine migration, and the initial heat will rapidly reduce to ambient temperatures in about 200 years because of radionuclide decay.

\subsection{Conclusions}

In conclusion, CH-TRU and RH-TRU wastes are essentially the same with respect to processes and mechanisms associated with gas generation, flammability and explosiveness, solubility, and brine and geochemical interactions. The processes that generate CH-TRU and RH-TRU waste are similar and include the same materials, with the exception of greater concentrations of short-lived radionuclides in the RH-TRU waste. These radionuclides exhibit high decay rates, so that the RH-TRU radionuclide inventory will begin to resemble the CH-TRU radionuclide inventory within a few hundred years. Therefore, the CH-TRU and RH-TRU radionuclide inventories will demonstrate the same behavior after the first few hundred years. 


\subsection{ANALYSIS OF THE IMPACT OF REMOTE-HANDLED WASTE ON PERFORMANCE ASSESSMENT}

This section of the RH-TRU Waste Study evaluates the impact of RH-TRU waste on the WIPP Performance Assessment (PA). It does not compare the CH-TRU waste impact to PA with that of RH-TRU waste. This evaluation includes an assessment of the PA activities that could potentially be affected by the inclusion of RH-TRU waste and its characteristics. The inventory considered in this evaluation includes the most current waste data as described in the WTWBIR [DOE, 1995e].

The EPA defined PA in 40 CFR Part 191 as “... an analysis that: (1) Identifies the processes and events that might affect the disposal system; (2) examines the effects of these processes and events on the performance of the disposal system; and (3) estimates the cumulative releases of radionuclides, considering the associated uncertainties, caused by all significant processes and events. These estimates shall be incorporated into an overall probability distribution of cumulative release to the extent practicable". [EPA, 1985]. DOE includes compliance with 40 CFR Part 268 in its evaluation of long-term repository performance [DOE, 1995g]. These regulations specify the EPA's environmental radiation protection standards for management and disposal of spent nuclear fuel and high-level and transuranic radioactive wastes, along with its regulations for the disposal of RCRAclassified hazardous waste.

Since the emphasis of this section is to describe the impact of RH-TRU waste on long-term repository performance, the features, events, and processes (FEPs) associated with RH-TRU waste and those that could potentially result in a regulatory violation must first be identified. The FEPs that are significant relative to the evaluation of RH-TRU wastes include gas generation, radionuclide migration by groundwater transport, cuttings releases by human intrusion, and radiolytic heat generation. These FEPs are described in the document entitled Systems Prioritization MethodIteration 2 Baseline Position Paper: Scenario Development for Long-Term Performance Assessments of the WIPP, dated March 17, 1995 [Galson et al., 1995]. The impact of these FEPs on PA relative to RH-TRU waste are discussed below. 
With respect to RCRA-regulated constituents, the CH-TRU and RH-TRU waste inventories are anticipated to be very similar, which is evident by the direct correlation of RCRA EPA codes reported in the WTWBIR for CH-TRU and RH-TRU wastes. Therefore, the contribution of RCRA constituents by the RH-TRU inventory to the total TRU inventory is anticipated to be very small due to the limited quantity of RH-TRU wastes to be received at WIPP and is therefore not specifically addressed in PA.

\subsection{Gas Generation}

Gas generation could occur in the waste-filled regions of the repository and is included as part of the modeling effort associated with the WIPP PA. The primary mechanisms identified as being important in influencirig the potential for gas generation are corrosion processes and microbial activity [Brush, 1995]. If sufficient quantities of gases are generated in the repository, elevated pressures exceeding lithostatic (approximately $15 \mathrm{MPa}$ ) could result. These elevated pressures could open fractures in the brittle anhydrite layers above and below the waste-disposal panels. Elevated pressures and/or fractures in the repository could also influence fluid flow and subsequent contaminant migration in and around the repository [Galson et al., 1995].

The PA process does not explicitly evaluate the gas potential contribution from RH-TRU waste alone; rather, it evaluates gas potential from the waste form distribution expected to be present in the total quantity of CH-TRU and RH-TRU waste. The comparison of CH-TRU and RH-TRU gas generating waste materials (section 3.2.1) has indicated that the amount of gas generated from RH-TRU corrodible and organic waste forms in the WIPP repository can range from approximately zero to 31 percent of the total corrodible waste inventory and approximately zero to 1 percent of the total organic waste inventory. However, the potential for anoxic corrosion to stop prior to producing significant quantities of gas and the potential for passivation of steel and other iron-base metals from microbial degradation products, along with an alternative design for the RH-TRU shield plug, would significantly reduce the expected range for gas generation from corrosion.

Sensitivity analyses on gas generation parameters have also been performed to provide perspective on compliance with EPA regulations in 40 CFR Part 191 and guidance for additional research. 
Through this process, the gas generation model parameters associated with the mass of the metals has been identified as having limited or no observed effects in an intrusion scenario [Sandia WIPP Project, 1991 and 1992]. Through WIPP PA modeling efforts, gas generation is coupled with brine inflow and outflow. Thus, the availability of water in the WIPP repository may limit anoxic corrosion and therefore hydrogen generation, regardless of the quantity of CH-TRU and RH-TRU steels and other iron-base alloys and packaging materials included in the WIPP inventory [Brush, 1995]. Calculations for undisturbed scenarios in the WIPP PA process involving gas generation indicated that none of the calculations resulted in 100 percent consumption of the CH-TRU iron-base alloys in 10,000 years [Howarth et al., 1995]. Therefore, any additional quantities of metal such as that represented in the RH-TRU waste inventory would not corrode for this scenario. From the RH-TRU waste inventory identified in the WTWBIR, it can be concluded that the RH-TRU gas generating corrodible metal waste represents the most significant contribution from RH-TRU waste to the total gas inventory. However, the potential for anoxic corrosion to stop prior to producing significant quantities of gas and the potential for passivation of steel and other iron-base metals from microbial degradation products, along with an alternative design for the RH-TRU shield plug, would significantly reduce this impact.

\subsection{Radionuclide Migration by Groundwater Transport}

Mobility of radionuclides in the repository is expected to be influenced by natural, waste, and repository-induced mechanisms (all of which are described below), as well as by human intrusion.

Microbial decomposition of organics in the waste may result in the transport of dissolved or colloidal radionuclides as complexes. Radionuclides will potentially migrate with groundwater to the accessible environment by advection, diffusion, and dispersion through the repository seals and backfill, as well as through the rock matrix and fractures in the interbeds [Howarth et al., 1995]. Other processes influencing radionuclide mobility include sorption, precipitation, and oxidationreduction reactions.

The following pathways have been identified in PA [Galson et al., 1995] as potentially leading to an eventual radionuclide release beyond the regulatory boundary under undisturbed repository conditions 
although no such release would occur until after the end of the 10,000-year period of regulatory concern. Disturbed conditions are considered below in subsection 4.3. These pathways are described below.

- A pressure gradient between the repository disposal rooms and the far field causes brine and any dissolved radionuclides to migrate into the anhydrite layers, which are more permeable than the halite typical of the Salado Formation. Once in the anhydrite layers, brine could then migrate to the base of shaft seals and up the shafts into the Culebra and then migrate out to the accessible environment.

- Brine may also continue to migrate laterally through the anhydrite layers until it reaches the subsurface boundary of the accessible environment in the Salado Formation.

- Brine could migrate directly via a pressure gradient from the waste disposal rooms vertically through the Salado Formation and into the Culebra.

Pathways identified above have been evaluated through the PA process. For the first two pathways, assuming seal properties similar to intact halite, calculations of brine transport have indicated that no brine from the repository will reach the accessible environment in the 10,000 years required to be evaluated by the PA [WIPP PA Department, 1992]. In the third case, it has been calculated that extremely long travel times, on the order of 400,000 years, would be required for brine to reach the Culebra [Lappin et al., 1989]. In the interest of being conservative, the PA did not consider the role that waste forms and waste containers might have in the retardation of contaminants under undisturbed conditions [DOE, 1995a].

Because of the long travel times required for brine to reach a regulated boundary by groundwater transport and because, compared to the CH-TRU inventory, the RH-TRU inventory is a very small contributor to radionuclide releases on these time scales, it can be concluded that radionuclides in RH-TRU waste have little impact on the PA. 


\subsection{Cuttings Releases by Human Intrusion}

Human intrusion is the FEP that PA has identified as having the most significant impact on radionuclide releases during the 10,000-year period of regulatory concern. Radionuclides could be released from the cuttings (direct cuttings plus material entrained by drilling fluid) associated with an intrusion borehole caused by drilling into the repository. However, the CUTTINGS model used to evaluate compliance has demonstrated that such cuttings releases would not exceed EPA's radiation standards [Sandia WIPP Project, 1992]. Figure 4-1 shows the complementary cumulative distribution

functions (CCDFs) for radionuclide releases predicted by the PA CUTTINGS model, using an updated inventory from the WTWBIR, both for combined CH-TRU and RH-TRU waste and for CH-TRU inventories alone.

A CCDF is a distribution function of releases (and associated probabilities of release) calculated from a set of input parameters. Because of the uncertainty in the models and the input parameters, PA calculations produce a set of CCDFs, each of which is calculated from a different set of sampled parameters. Each CCDF relates the probability of a set of occurrences or events that can take place to the probability of the set of consequences that can happen if they do occur. Figure 4-1 demonstrates the relationship between the magnitude of a radionuclide release via borehole cuttings to the probability that these releases will exceed EPA release limits. The straight stairstep-like line in this figure represents the summed normalized EPA limits for radionuclide releases. If a CCDF curve were to extend to the right of the normalized standards curve, it could be concluded that a violation of the standards would occur. The EPA has stated that "a disposal system can be considered to be in compliance with 40 CFR Part 191.13 if this single distribution function meets the requirements of 40 CFR Part 191.13a (the stairstep EPA release limits)." Figure 4-1 shows the mean probability of a release for a set of CCDFs.

Examination of the two CCDF figures reveals that there is no observable impact from the RH-TRU contribution to the waste inventory on the probability of a radionuclide release to exceed EPA standards. These CCDFs considered human intrusion to occur over the time period of 100 to 10,000 years. Table 4-1 identifies the projected activity levels in WIPP over the compliance period 


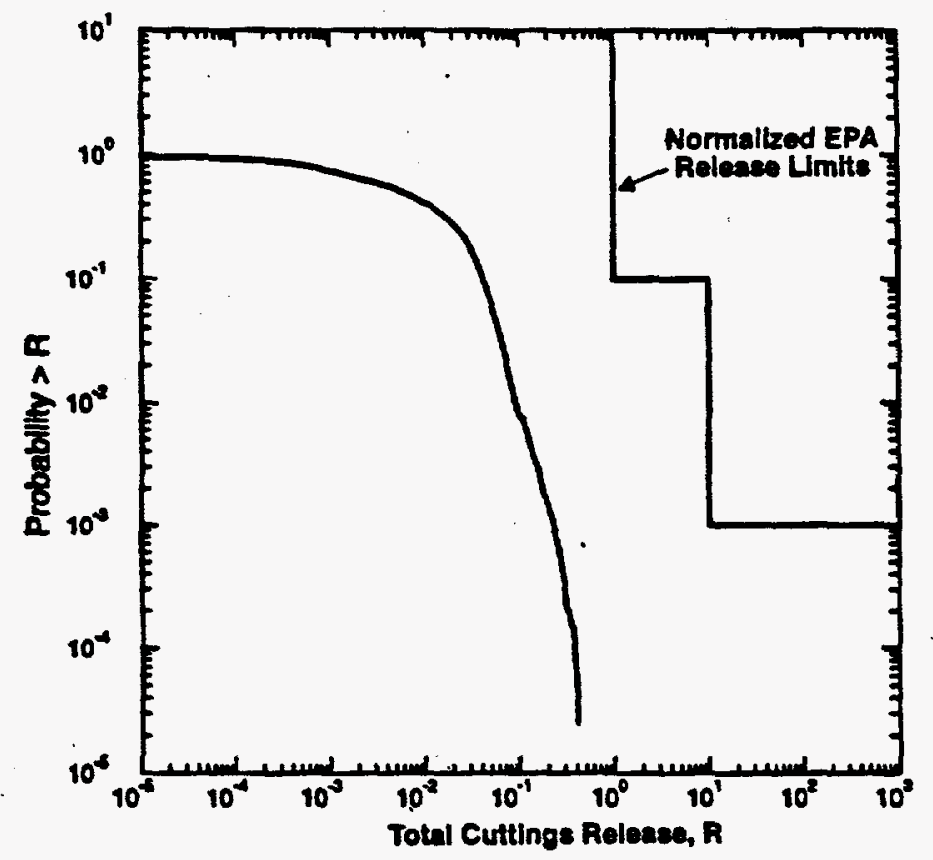

Mean CCDF for Combined CH-TRU and RH-TRU Waste Inventory

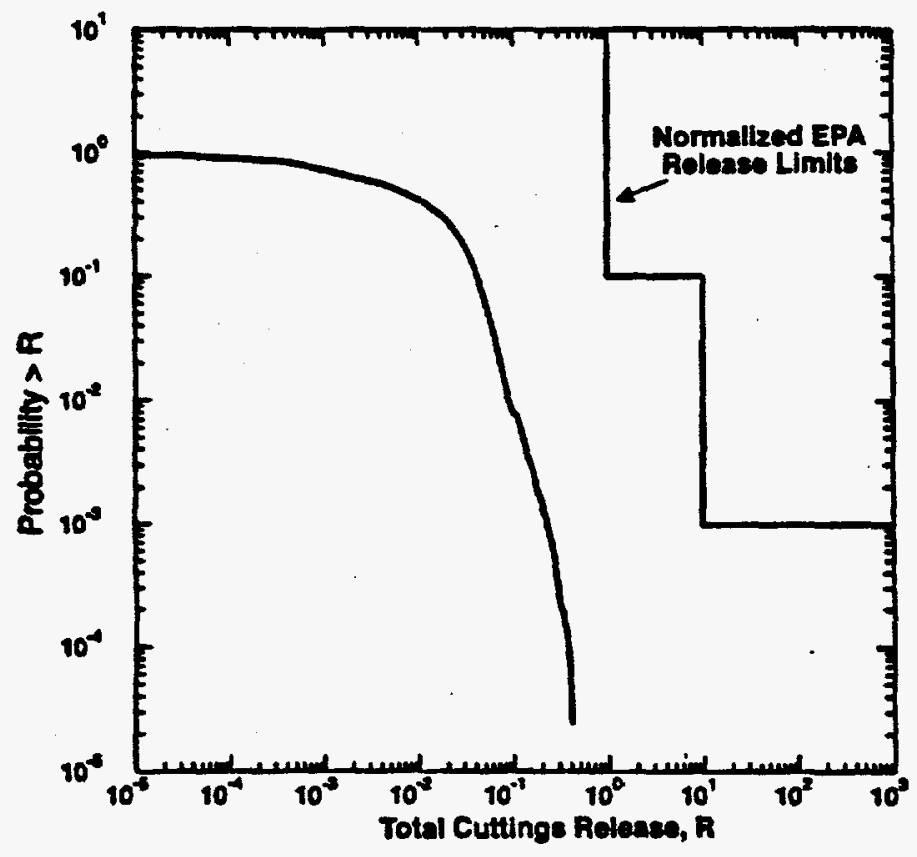

Mean CCDF for CH-TRU Waste Inventory

Figure 4-1. CUTTINGS Model CCDFs 
Table 4-1. Projected Activity Levels $\left(\mathrm{Ci} / \mathrm{m}^{2}\right)$ in the WiPP Due to Waste That Is Currently Stored and May Be Shipped to the WIPP

\begin{tabular}{|c|c|c|c|c|c|c|c|c|c|c|c|}
\hline \multirow{2}{*}{$\begin{array}{l}\text { Actlvity } \\
\text { Level }\end{array}$} & \multirow{2}{*}{ Type" } & \multirow{2}{*}{ Probability } & \multicolumn{9}{|c|}{ Time (yr) } \\
\hline & & & 0 & 100 & 125 & 175 & 350 & 1000 & 3000 & 7250 & 10,000 \\
\hline 1 & $\mathrm{CH}^{\circ}$ & 0.3968 & 1.2656 & 0.5442 & 0.4848 & 0.3969 & 0.2538 & 0.1748 & 0.1459 & 0.1251 & 0.1142 \\
\hline 2 & $\mathrm{CH}$ & 0.3572 & 12.656 & 5.442 & 4.848 & 3.969 & 2.538 & 1.748 & 1.459 & 1.251 & 1.142 \\
\hline 3 & $\mathrm{CH}$ & 0.1259 & 126.56 & 54.42 & 48.48 & 39.69 & 25.38 & 17.48 & 14.59 & 12.51 & 11.42 \\
\hline 4 & CH & 0.0060 & 1265.6 & 544.2 & 484.8 & 396.9 & 253.8 & 174.8 & 145.9 & 125.1 & 114.2 \\
\hline 5 & $\mathbf{R} H^{\mathbf{d}}$ & 0.1141 & 70.310 & 11.494 & 6.630 & 2.436 & 0.577 & 0.537 & 0.578 & 0.644 & 0.667 \\
\hline \multicolumn{3}{|c|}{ Average of CH Waste: } & 32.192 & 13.842 & 12.330 & 10.096 & 6.456 & 4.445 & 3.710 & 3.182 & 2.904 \\
\hline
\end{tabular}

a CH designates contact-handled waste; RH designates remote-handled waste.

b Probability that a randomly placed borehole through the waste panels will intersect waste with activity levels $1,2,3,4$, or 5 for $\mathrm{CH}$ and $\mathrm{RH}$ inventory.

c CH activity levels based on $111,520 \mathrm{~m} 2$ total surface area.

d RH activity levels based on $14,360 \mathrm{~m} 2$ total surface area. 
based on the WTWBIR. The CH-TRU waste was partitioned into four activity levels with a probability associated with each activity level. The RH-TRU waste was evaluated at one activity level. The probability for the RH-TRU activity level (5) is based on the relative area of RH-TRU waste emplacement to the total waste emplacement area. This table includes the probabilities for the assessment of both CH-TRU and RH-TRU human intrusion. When the CH-TRU inventory was evaluated alone, the RH-TRU intrusions were simply not included in the calculations as a release.

There are several observations that can be made from Table 4-1 that explain the results from comparing the CCDFs in Figure 4-1. Table 4-1 shows that the probability of hitting RH-TRU waste if an intrusion occurs is 0.1141 and that after 175 years the release from an intrusion into an RH-TRU waste canister is less than the release from $\mathrm{CH}$-TRU waste activity level 2,3 , or 4 . The probability of an intrusion into activity levels 2,3 , and 4 is 0.4891 . After 350 years, the activity level of the RH-TRU waste is slightly larger than the activity of CH-TRU activity level 1 . The probability of hitting CH-TRU waste activity level 1 if an intrusion occurs is 0.3968 compared to 0.1141 for RH-TRU. To identify an effect of RH-TRU waste on the CCDFs, the intrusion into the lower probability RH-TRU canister must be calculated and the release from this intrusion must be significant in comparison to intrusions calculated for the range of activity levels of CH-TRU. The identical CCDFs indicate that there were no significant consequences from intrusions into RH-TRU canisters compared to the CH-TRU activity levels.

It can be concluded, then, that RH-TRU waste has little or no contribution to radionuclide releases that may be caused by a human intrusion drilling activity, and therefore there is minimal impact on the WIPP PA.

\subsection{Radiolytic Heat Generation}

Two concerns have been identified relative to radiolytic heat generation in the repository. The first is the potential for fractures to develop around the waste-filled regions or in repository seals and backfill from thermally induced stress. Fracturing of the formation could provide pathways in which contaminated brine could migrate toward the regulatory boundary [Galson et al., 1995]. The second is related to thermal convection that could enhance water-vapor transport in the gas phase. As this 
gas travels away from the heat-generating waste forms into cooler regions of the waste disposal rooms, the potential exists for greater contact between the waste and liquid water due to condensation of the water vapor [Butcher et al., 1995]. A detrimental effect of these occurrences could be an earlier-than-anticipated release of radionuclides beyond the regulatory boundary because most of the heat developed as a result radiolytic decay of RH-TRU waste will occur early in the postclosure period. If a release occurred within the first 200 years after disposal, radionuclides from RH-TRU waste could potentially contribute to that release.

To determine whether heat generation would have an impact on the performance of the repository, two WIPP-specific studies [Arguello and Torres, 1988; Molecke et al., 1993] regarding heat and thermal effects from RH-TRU waste were examined. The 1988 study utilized a two-dimensional, nonlinear heat conduction finite-element code. The reference case used in model analysis assumed a heat output of $60 \mathrm{~W}$ per canister, which resulted in a maximum formation temperature rise of about $3.5^{\circ} \mathrm{C}$ above an assumed ambient of $27^{\circ} \mathrm{C}$ over a 6 -year period.

The 1993 study [Molecke et al., 1993] included in-situ experiments to ascertain the impacts of heat in the repository. Temperature results were monitored over a 5-year period while evaluating two heat output conditions, of 115 and $300 \mathrm{~W}$. The temperatures observed in the first condition ranged from 3 to $4^{\circ} \mathrm{C}$ above ambient as measured at the top of the borehole-air interface. In the second condition, the temperatures were on the order of 7 to $9^{\circ} \mathrm{C}$ above ambient. The ambient formation temperature for these test conditions was about $28^{\circ} \mathrm{C}$.

These studies indicate that insufficient heat will be generated from RH-TRU waste to promote formation of fractures or significant quantities of water vapor and therefore will have no significant impact on PA. This conclusion is especially true as the anticipated. initial heat output from the RH-TRU waste canisters is about $1.0 \mathrm{~W}$ (as estimated from the TRU radionuclide inventory, Appendix B) and is well below the range of 60 to $300 \mathrm{~W}$ evaluated in these studies. 


\subsection{Conclusions}

From this evaluation of the impact of RH-TRU waste on PA it can be concluded that the effect on the expected repository performance from the RH-TRU waste component of the TRU waste inventory will be insignificant over the long term. The four FEPs identified as having a potential contribution to repository performance due to the RH-TRU waste inventory have demonstrated minimal effects for two primary reasons. The first reason is the small contribution of RH-TRU waste based on the volume ( 5 percent) of the total inventory. Gas generation by the waste inventory has been shown in section 3.0 to be dependent on the brine inflow; therefore, the addition of the RH-TRU inventory should not significantly increase the total gas inventory. The second is that the high concentrations of radionuclides unique to the RH-TRU waste decay rapidly over a short period of time relative to the 10,000-year regulatory compliance period. Of chief importance is that RH-TRU waste will begin to exhibit essentially the same radiological characteristics as CH-TRU waste after the first few hundred years of disposal. 


\subsection{REFERENCES}

Arguello, J. G., and T. M. Torres, 1980, Thermal Effects of RH TRU Waste Emplacement on WTPP Storage Room Thermal/Structural Response, SAND88-2217, October 1980.

Brush, L. H., M. A. Molecke, A. R. Lappin, R. E. Westerman, X. Tong, J. N. P. Black, D. GrbicGalic, R H. Vreeland, and D. T. Reed, 1991, "Laboratory and Bin-Scale Tests of Gas Generation for the Waste Isolation Pilot Plant," Waste-Generated Gas at the Waste Isolation Pilot Plant: Papers Presented at the Nuclear Energy Agency Workshop on Gas Generation and Release from Radioactive Repositories, P. B. Davies, L. H. Brush, M. A. Molecke, F. T. Mendenhall, and S. W. Webb, eds., pp. 2-1-2-14, SAND91-2378, Sandia National Laboratories, Albuquerque, New Mexico.

Brush, L. H., M. A. Molecke, R. E. Westerman, A. J. Francis, J. B. Gillow, R. H. Vreeland, and D. T. Reed, 1993, "Laboratory Studies of Gas Generation for the Waste Isolation Pilot Plant," Scientific Basis for Nuclear Waste Management XVI, Materials Research Society Symposium Proceedings, Boston, Massachusetts, November 30-December 4, 1992, C. G. Interrante and R. T. Pabalan, eds., Vol. 294, pp. 335-340, Materials Research Society, Pittsburgh, Pennsylvania; SAND92-2160C.

Brush, L. H., 1995, Systems Prioritization Method-Iteration 2, Baseline Position Paper: Gas Generation in the Waste Isolation Pilot Plant, Sandia National Laboratories, March 17, 1995.

Butcher, B. M., S. W. Webb, J. W. Berglund, and P. R. Johnson, 1995, Systems Prioritization Method-Iteration 2, Baseline Position Paper: Disposal Room and Cuttings Models, Volume I, March 20, 1995.

DOE: see U.S. Department of Energy.

EPA: see U.S. Environmental Protection Agency.

Galson, D. A, T. W. Hicks, R. D. Wilmont, and P. N. Swift, 1995, Systems Prioritization MethodIteration 2, Baseline Position Paper: Scenario Development for Long-Term Performance Assessments of the WIPP, 9203d-10, Version 4.2, March 17, 1995.

Howarth, S., K. Larson, T. Christian-Frear, R. Beauheim, D. Borns, D. Deal, A. L. Jensen, K. Knowles, D. Powers, R. Roberts, M. Tierney, and S. Webb, 1995, "Systems Prioritization Method-Iteration 2, Baseline Position Paper: Salado Formation Fluid Flow and Transport Containment Group," March 17, 1995.

Hull, A. B., 1987, Kinetics of Evaporite Mineral-Brine Interactions: Mathematical Modeling and Experimental Determination of the Effect of Gamma Radiation and Threshold Crystallization Inhibition on Permian Basin Brine Composition, UNO2522, Ph.D. Dissertation, Northwestern University, August 1987. 
Jenks, G. H., and C. D. Bopp, 1977, Storage and Release of Radiation Energy in Salt in Radioactive Waste Repositories, ORNL-5058, Oak Ridge National Laboratory, Oak Ridge, Tennessee, October 1977.

Lappin, A. R., R. L. Hunter, D. P. Garber, and P. B. Davies, eds., 1989, Systems Analysis, LongTerm Radionuclide Transport, and Dose Assessments, Waste Isolation Pilot Plant (WIPP), Southeastern New Mexico, March 1989, SAND89-0462, Sandia National Laboratories, Albuquerque, New Mexico.

Levy, W. P., 1983, "Radiation Damage Studies on Natural Rock Salt from Various Geological Localities of Interest to the Radioactive Waste Disposal Program," Nuclear Technology, Vol. 60, pp. 231-243, February 1983.

Molecke, M. A, 1979, Gas Generation From Transuranic Waste Degradation: Data Summary and Interpretation, SAND79-1245, Sandia National Laboratories, Albuquerque, New Mexico.

Molecke, M. A., et al., 1993, Waste Isolation Pilot Plant Simulated RH TRU Waste Experiments: Data and Interpretation Report, SAND88-1314, April 1993.

Novak, C. F., N. J. Dhooge, H. W. Papenguth, and R. F. Weiner, 1995, "Systems Prioritization Method-Iteration 2, Baseline Position Paper: Actinide Source Term," Sandia National Laboratories, March 31, 1995.

Nuclear Packaging, Inc., 1992, Safety Analysis Report for the TRUPACT-II Shipping Package, Revision 12, September 1992.

Olander, D. R, 1984, A Study of Thermal-Gradient-Induced Migration of Brine Inclusions in Salt: Final Report, BMI/ONWI-538, Battelle Memorial Institute, Columbus, Ohio, August 1984.

Panno, S. V., and P. Soo, 1984, "Potential Effects of Gamma Irradiation on the Chemistry and Alkalinity of Brine in High-Level Nuclear Waste Repositories in Rock Salt," Nuclear Technology, Vol. 67, pp. 268-281, November 1984.

Pederson, L. R, 1985, Chemical Implications of Heat and Radiation Damage to Rock Salt, Vol. 44, pp. 701-708, Materials Research Society, Pittsburgh, Pennsylvania, 1985.

Public Law 96-164, 1979, Department of Energy National Security and Military Applications of Nuclear Energy Authorization Act of 1980.

Public Law 102-579, 1992, Waste Isolation Pilot Plant Land Withdrawal Act, October 30, 1992.

Sandia WIPP Project, 1991, Preliminary Comparison with 40 CFR 191, Subpart B for the Waste Isolation Pilot Plant, December 1991, SAND91-0893, December 1991.

Sandia WIPP Project, 1992, Preliminary Performance Assessment for the Waste Isolation Pilot Plant, December 1992, Volumes 1-4, SAND92-0700, December 1992. 
Slezak, S., and A. Lappin, 1990, "Potential for and Possible Impacts of Generation of Flammable and/or Detonable Gas Mixtures During the WIPP Transportation, Test, and Operational Phases," Sandia National Laboratories memorandum to Department of Energy, January 5, 1990.

U.S. Department of Energy, 1980, Final Environmental Impact Statement, Waste Isolation Pilot Plant, DOE/EIS-0026, October 1980.

U.S. Department of Energy, 1988, DOE Order 5820.2A: Radioactive Waste Management, September 26, 1988.

U.S. Department of Energy, 1991, Waste Acceptance Criteria for the Waste Isolation Pilot Plant, Revision 4.0, WIPP-DOE-069, December 1991.

U.S. Department of Energy, 1994, Comparative Study of Waste Isolation Pilot Plant (WTPP) Transportation Alternatives, DOE/WIPP 93-058.

U.S. Department of Energy, 1995a, "Draft 40 CFR 191 Compliance Certification Application for the Waste Isolation Pilot Plant, Phase II Review," DOE/CAO Predecisional Draft-2056, February 10, 1995.

U.S. Department of Energy, 1995b, "Implementation Plan for the Remote Handled TRU Waste Performance Assessment and Comparison to Contact Handled Waste," DOE memorandum, January. 1995.

U.S. Department of Energy, 1995c, WIPP Stakeholder Meeting, Remote-Handled Transuranic Waste Study, Robert A. Bills, DOE/Carlsbad Area Office, April 7, 1995.

U.S. Department of Energy, 1995d, Waste Isolation Pilot Plant Remote-Handled Transuranic Waste Disposal Strategy, DOE/WIPP-95-1090, March 31, 1995.

U.S. Department of Energy, 1995e, Waste Isolation Pilot Plant Transuranic Waste Baseline Inventory Report, Revision 1, CAO-94-1005, February 1995.

U.S. Department of Energy, 1995f, Transuranic Waste Characterization Quality Assurance Program Plan (QAPP), Revision 0, April 30, 1995.

U.S. Department of Energy, 1995g, Strategic Plan, Revision 1, DOE/WIPP 93-025, March 1995.

U.S. Department of Energy and State of New Mexico, 1981, as modified, "Agreement for Consultation and Cooperation Between the Department of Energy and the State of New Mexico on WIPP," July 1, 1981 (updated through April 18, 1988).

U.S. Environmental Protection Agency, 1985, 40 CFR Part 191: "Environmental Standards for the Management and Disposal of Spent Nuclear Fuel, High-Level and Transuranic Radioactive Wastes, Final Rule," Federal Register, Vol. 50, No. 182, 38066-38089. 
U.S. Environmental Protection Agency, 1990, Department of Energy Waste Isolation Pilot Plant: Notice of Final No-Migration Determination, November 14, 1990.

VECTRA Technologies, Inc., 1994, Safety Analysis Report for the RH-TRU 72-B Waste Shipping Package, Revision 0, December 1994.

WIPP Performance Assessment Department, 1992, Long-Term Gas and Brine Migration at the Waste Isolation Pilot Plant: Preliminary Sensitivity Analyses for Post Closure 40 CFR 268 (RCRA), May 1992, SAND92-1933, December 1992. 


\subsection{GLOSSARY OF TERMS}

Term

Accessible Environment

Actinide

Activity

Alpha Radiation

Anhydrite

Anoxic Corrosion

Beta Radiation

Brine

Canister

Cask

\section{Definition}

"(1) The atmosphere, (2) land surfaces, (3) surface waters, (4) oceans, and (5) all of the lithosphere that is beyond the controlled area" (40 CFR Part 191.12).

An element in the actinide series beginning with element 89 and continuing through 103. All the transuranic nuclides considered in this document are actinides.

A measure of the rate at which a material emits nuclear radiation, usually given in terms of the number of nuclear disintegrations occurring in a given length of time. The unit of activity used in this document is the curie $(\mathrm{Ci})$.

A positively charged particle emitted in the radioactive decay of certain nuclides. Made up of two protons and two neutrons bound together, it is identical to the nucleus of a helium atom. It is the least penetrating of the three common types of radiationalpha, beta, and gamma radiation.

A mineral consisting of anhydrous calcium sulfate $\left(\mathrm{CaSO}_{4}\right)$. It is gypsum without water but is denser, harder, and less soluble.

Corrosion of metals by chemical decomposition in the absence oxygen.

A negatively charged particle emitted in the radioactive decay of certain nuclides; a free electron.

Saline water containing calcium $(\mathrm{Ca})$, sodium $(\mathrm{Na})$, potassium $(\mathrm{K})$, chlorides $(\mathrm{Cl})$, and minor amounts of other elements located in deep sedimentary basins.

As used in this document, a container, usually cylindrical, for remotely handled TRU waste. The waste will remain in this canister during and after burial. A canister affords physical containment but not shielding; during shipment, shielding is provided by a cask.

A massive shipping container providing shielding for highly radioactive materials and holding one or more canisters. 
Certification

Complementary

Cumulative Distribution Function (CCDF)

Consultation and

Cooperation Agreement

Contact-Handled (CH) Waste

Containment

Culebra Dolomite

Curie (Ci)

Cuttings
Any action taken by the Administrator of the U.S. Environmental Protection Agency under Section 8(d) of the WIPP Land Withdrawal Act.

A graphical display of the probability of an occurrence (the ordinate) and a quantitative measure associated with that occurrence (the abscissa). For the WIPP, a CCDF shows the probability of occurrence of specific scenarios and the cumulative radionuclide releases estimated to result from those scenarios. Radionuclide releases are normalized as stipulated in 40 CFR Part 191, Appendix A, and the CCDF is compared to the quantitative release limits specified in 40 CFR Part 191.13(a).

An agreement that affirms the intent of the Secretary of Energy to consult and cooperate with the State of New Mexico with respect to state public health and safety concerns. The term "Agreement" means the July 1, 1981, Agreement for Consultation and Cooperation, as amended by the November 30, 1984, "First Modification," the August 4, 1987, "Second Modification," and the March 22, 1988, modification to the Working Agreement.

Transuranic waste that has a measured radiation dose rate at the container surface of 200 millirems per hour or less and can be safely handled without. special equipment when placed in containers.

The retention of radioactivity within prescribed boundaries, such as within a waste package. In this document, containment usually refers to retention within a system to exclude its release to the biosphere in unacceptable quantities or concentrations.

The lower of two layers of dolomite within the Rustler Formation that are locally water bearing.

A quantitative measure of radioactivity equal to $3.7 \times 10^{10}$ disintegrations per second.

During exploratory drilling, waste contained in the cylindrical volume created by the cutting action of the drill bit through the waste. This volume is approximated by the cross-sectional area of the drill bit multiplied by the repository thickness. 
Daughter Product

Decay, Radioactive

Disposal

Disposal System

Disturbed Performance

Dose

Dose Rate

Emplacement

Fission Products
A nuclide that results from radioactive decay. Thus radium-226 decays to radon-220, which in turn decays to polonium-216. The radon is the daughter of the radium, and polonium is its daughter.

The decrease in the number of radioactive nuclei present in a radioactive material due to their spontaneous transmutation. Also, the transmutation of a radionuclide into another nuclide by the emission of a charged particle.

The term "disposal" means permanent isolation of transuranic waste from the accessible environment with no intent of recovery, whether or not such isolation permits the recovery of such waste. Disposal of waste in a mined geologic repository occurs when the waste has been emplaced and all the shafts to the repository are sealed.

The disposal system is any combination of engineered and natural barriers that isolate transuranic waste after disposal. For the purposes of the Waste Isolation Pilot Plant, this will include the combination of the repository/shaft system and the controlled area.

This means the predicted behavior of the disposal system, including consideration of the uncertainties in predicted behavior, if the disposal system is disrupted by human intrusion (i.e., scenarios in which the waste-disposal region is intruded by an exploratory borehole).

A general term indicating the amount of energy adsorbed per unit mass from incident radiation.

The rate at which dose is delivered.

At the Waste Isolation Pilot Plant, the placing of radioactive wastes in the repository.

Fissile products means any material consisting of or containing one or more fissile radionuclides. Fissile radionuclides are plutonium-238, plutonium-239, plutonium-241, uranium-233, and uranium-235. 
Formation (Geologic)

Gamma Radiation

Gas Generation

Generator and/or Storage Sites:

Groundwater

Half-life

Halite

Hot Cell

Human Intrusion

Interbeds

Irradiation
The basic rock-stratigraphic unit in the local classification of rocks. It consists of a body of rock (usually sedimentary) generally characterized by some degree of internal lithologic homogeneity or distinctive features.

Short wavelength electromagnetic radiation (high-energy photon) emitted in the radioactive decay of certain nuclides.

The combined gas production from all species of gases produced as a result of transuranic waste transformations such as corrosion, microbial degradation, and/or radiolysis at any given time. The rate of gas production throughout the history of the repository is expected to vary depending on repository conditions with respect to humidity, total or partial brine inundation, competitive reactions that absorb specific gases, and the ability of the repository to retain the gases generated. The term is also applied to individual gases.

Refers to the Department of Energy sites nationwide where transuranic wastes are generated and/or stored as a result of activities associated with nuclear weapons production.

Water below the land surface in a zone of saturation (40 CFR Part 191.12).

The time required for the activity of a group of identical radioactive nuclei to decay to half its initial value.

The mineral rocksalt: $\mathrm{NaCl}$.

A heavily shielded compartment in which highly radioactive material can be handled, generally by remote control.

In advertent human disruptions of a mined geologic repository that could result in loss of containment of the waste. The most severe disruption would occur through inadvertent, intermittent intrusion by exploratory drilling (into the repository) for resources (40 CFR Part 191, Appendix C).

Stratigraphic horizons of geologic material within a larger horizon.

Exposure to any form of radiant energy. 
Isotope

Land Withdrawal Act (LWA)

Lithostatic Pressure

Long-term

Lower Explosive Limit (LEL)

Mean

Microbial Degradation

No-Migration

Determination
A species of atom characterized by the number of protons and the number of neutrons in its nucleus. In most instances an element can exist as any of several isotopes, differing in the number of neutrons, but not the number of protons, in their nuclei. Isotopes can be either stable isotopes or radioactive isotopes (also called radioisotopes or radionuclides).

Public Law 102-579, which withdraws the land at the Waste Isolation Pilot Plant site from "entry, appropriation, and disposal"; transfers jurisdiction of the land from the Secretary of the Interior to the Secretary of Energy; reserves the land for activities associated with the development and operation of the Waste Isolation Pilot Plant; and includes many other requirements and provisions pertaining to the protection of public health and the environment.

Subsurface pressure due to the weight of overlying rock or soil.

Refers to the 10,000 years after shaft sealing for which performance assessment calculations and models assess the behavior of the repository with respect to compliance with 40 CFR Part 191 and 40 CFR Part 268.6.

The minimum concentration of gas or vapor in air below which a substance does not burn when exposed to an ignition source.

The average value. For a given set of $n$ values, the mean is the sum of their values divided by $n$.

The process of consumption by microbial substances-usually organic materials such as cellulosics.

In the context of the Test Phase, the term "no-migration determination" means the Final Conditional No-Migration Determination for the Department of Energy Waste Isolation Pilot Plant published by the Environmental Protection Agency on November 14, 1990 (55 Fed. Reg. 47700), and any amendments thereto, pursuant to the Solid Waste Disposal Act (42 U.S.C. 6901 et seq.). The Department of Energy has decided not to pursue the testing activities in the WIPP underground for which the conditional No-Migration Determination was made.

Nuclide

Isotope. 
Nuclide Inventory

(Radionuclide Inventory)

Oxic Corrosion

Performance Assessment

(PA)

pH

Post-Closure Phase

Process Knowledge

Public Law 96-164

Public Law 102-579

$\operatorname{Rad}$

Radiolysis

Radionuclide

Release
A list of the kinds and amounts of radionuclides in a container or a source. Amounts are usually expressed in activity units: curies or curies per unit volume.

Oxidation of metals by molecular oxygen $\left(\mathrm{O}_{2}\right)$.

A term used to denote quantitative activities carried out to evaluate the long-term ability of the Waste Isolation Pilot Plant to effectively isolate the waste, to ensure long-term health and safety of the public by complying with 40 CFR Part 191 and 40 CFR Part 268.6, and to supply data/information to the compliance analysis for demonstrating regulatory compliance. The final analysis of compliance will consist or a qualitative assessment of the quantitative results of the performance assessment.

A term used to describe the hydrogen-ion activity or concentration of a solution.

A designated period of time beginning with the end of the Decommissioning Phase and extending through the end of the regulatory time frame of 10,000 years. Performance assessment modeling of repository behavior will address this time frame with the exception of possible human intrusion events, which will not be modeled until 100 years after decommissioning.

The detailed knowledge of the processes and materials that generated the wastes in the DOE system.

The U.S. Department of Energy National Security and Military Applications of Nuclear Energy act of 1980. Public Law 96-164 directed the Department of Energy to proceed with the design and development of the Waste Isolation Pilot Plant.

See Land Withdrawal Act.

A unit of absorbed dose. Related to but not the same as "rem."

Chemical decomposition by the action of radiation.

Any isotope that emits radiation from its nucleus.

Movement of regulated substances into the accessible environment as defined in 40 CFR Part 191 or beyond the unit boundary as defined for 40 CFR Part 268.6. 
Rem

Remote-Handled (RH)

Waste

Repository

Saturated

Scenario

Solubility

Source Term

Specific Activity

Stabilization

Standard Waste Box (SWB)
Roentgen equivalent in man-a special unit of dose equivalent that is the product of absorbed dose, a quality factor that rates the biological effectiveness of the radiation types producing the dose, and other modifying factors (usually equal to one). If the quality and modifying factors are unity, 1 rem is equal to $1 \mathrm{rad}$ : $100 \mathrm{rem}$ $=1$ Sievert (SI units). Also expressed in terms of millirem (mrem): 1 rem $=1,000$ mrem.

Transuranic wastes that have a measured radiation dose rate at the container surface of between 200 mrems per hour and 1,000 rems per hour and, therefore, must be shielded for safe handling.

The portion of the Waste Isolation Pilot Plant underground system within the Salado Formation, including the access drifts, waste panels, and experimental areas, but excluding the shafts.

A condition in which all connected pores in a given volume of material contain fluid.

A combination of naturally occurring or human-induced events and processes that represent realistic future changes to the repository, geologic, and geohydrologic systems that could affect disposal system performance.

The ability or tendency of one substance to blend uniformly with another (e.g., solid in liquids, liquid in liquid, gas in liquid, and gas in gas). Solids vary from 0 to 100 percent in their degree of solubility in liquids depending on the chemical nature of the substance(s); to the extent that they are soluble, they lose their crystalline form and become molecularly or ionically dispersed in the solvent to form a true solution. Liquids and gases are often said to be miscible in other liquids and gases rather than soluble.

The kinds and amounts of radionuclides that make up the source of a potential release of radioactivity.

Radioactivity per unit mass of radioactive material.

The mixture and encasement of radioactive materials in cement or grout.

A waste container measuring approximately 6 by 4.5 by 3 feet high, with rounded ends. 
Transuranic (TRU)

Nuclide

Transuranic (TRU) Waste

Treatment

Undisturbed Performance

Vitrification

Volatile Organic

Compounds (VOCs)

Waste Acceptance

Criteria (WAC)

Waste Form
A nuclide with an atomic number greater than that of uranium (92). All transuranic nuclides are produced artificially and are radioactive.

The term "transuranic waste" means waste containing more than 100 nanocuries of alpha-emitting transuranic isotopes per gram of waste, with half-lives greater than 20 years, except for: (1) highlevel radioactive waste; (2) waste that the Secretary has determined, with the concurrence of the Administrator, does not need the degree of isolation required by the disposal regulations; or (3) waste that the Nuclear Regulatory Commission has approved for disposal on a case-by-case basis in accordance with 10 CFR Part 61.

Means any method, technique, or process, including neutralization, designed to change the physical, chemical, or biological character or composition of any hazardous waste so as to neutralize such waste, or so as to recover energy or material resources from the waste, or as to tender such waste nonhazardous, or less hazardous; safe to transport, store, or dispose of; or amenable for recovery, amenable for storage, or reduced in volume.

"[T]he predicted behavior of a disposal system, including consideration of the uncertainties in predicted behavior, if the disposal system is not disrupted by human intrusion or the occurrence of unlikely natural events." (40 CFR Part 191.12)

Vitrification is the mixture of radioactive materials with glass by the action of heat.

RCRA-regulated organic compounds that readily pass into the vapor state and are present in contact-handled transuranic mixed waste.

A set of conditions established for permitting transuranic wastes to be packaged, shipped, managed, and disposed of at the Waste Isolation Pilot Plant.

A term used to emphasize the physical and chemical properties of the waste. 


\section{APPENDIX A}

\section{RH-TRU SHIELD PLUG AND CANISTER DESCRIPTION}




\section{APPENDIX A \\ RH-TRU SHIELD PLUG AND CANISTER DESCRIPTION}

The RH-TRU waste canister was designed by Rockwell Hanford Operations to be used by defense waste generator sites in the United States. The canister is designed to be compatible with the requirements of WIPP and the WIPP handling system. The RH waste canister is designed to be vented through a high-efficiency particulate air (HEPA) filter and to meet the DOT "type A" container requirements in 49 CFR $173.400-478$. The canister is designed to withstand a 4-ft drop and temperatures to $-40^{\circ} \mathrm{F}$. Each canister is 121 in $(3.1 \mathrm{~m})$ long and 26 in $(0.7 \mathrm{~m})$ in diameter, is topped with a standard WIPP pintle, and has a maximum internal volume of $0.89 \mathrm{~m}^{3}$. The RH-TRU canister was designed to incorporate three standard (DOT 7C) CH-TRU waste drums, each 55 gallons (210 liters) in volume. The canister weighs $1,760 \mathrm{lbs}(800 \mathrm{~kg})$, with a maximum gross weight of $8,000 \mathrm{lbs}(3,629 \mathrm{~kg})$, and has a total surface area of approximately $1.2 \times 10^{4} \mathrm{in}^{2}\left(7.7 \mathrm{~m}^{2}\right)$.

The canister design utilizes the American Society of Mechanical Engineers (ASME) standard for flanged and reversed dished with flare head. Each canister is fabricated out of ASTM A156-82 grade 70 mild steel, 0.25 in (6.4 mm) thick [Rockwell International, 1984]. 


\section{Canister}
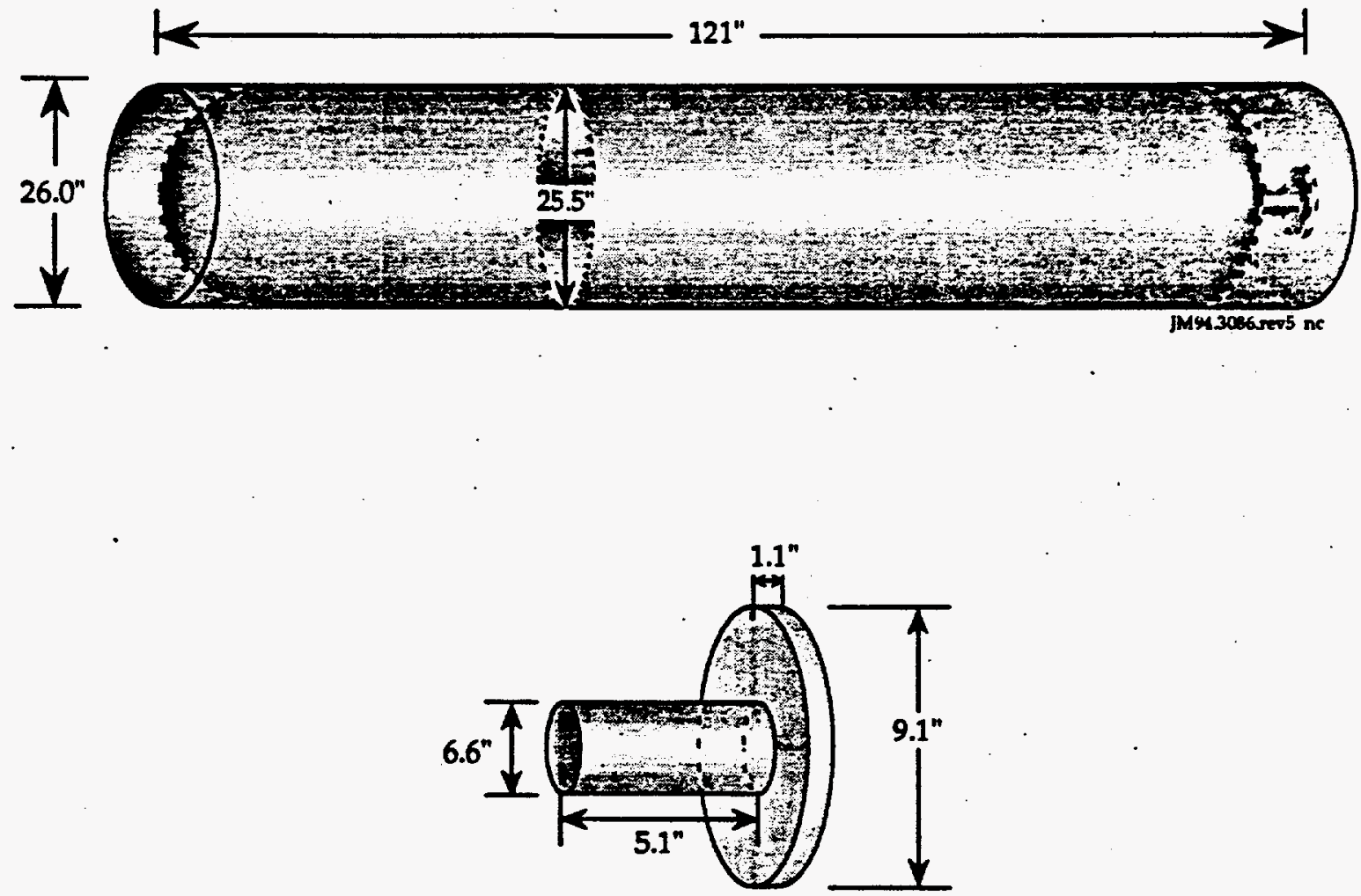

Note:

Drawing Not to Scale

- These are nominal estimates which support the inventory assessment for corrodible metals. 
The RH-TRU waste shield plug was designed by Westinghouse Electric Corporation's Waste Technology Services Division (WTSD) for use by the WIPP project for worker radiation protection when RH canisters are emplaced into horizontal boreholes of the repository rooms and panels. Each plug is 70.0 in $(1.8 \mathrm{~m})$ long with a pintle length of 6.25 in $(1.6 \mathrm{~cm})$, for an overall length of 76.25 in $(1.9 \mathrm{~m})$. Each plug has a 29.0 -in $(0.8-\mathrm{m})$ outside diameter and a 25.5 -in $(0.7-\mathrm{m})$ inside diameter. The inner end plate of the RH plug is 25.0 in $(0.1 \mathrm{~m})$ thick and the outer end plate is 23.0 in $(0.1 \mathrm{~m})$ thick. Each plug is fabricated out of ASTM A27 GR, MI steel for the hollow cylinder and ASTM A36 steel for each plate. Each plug weighs 4,215 lbs (1,912 kg).

Each shield plug is to be inserted into the borehole following the emplacement of the RH canister in the repository rooms and panels. The shield plug serves to limit the radiation surface dose rate to the disposal room to less than $5 \mathrm{mrem} / \mathrm{hr}$ after the emplacement of the RH waste canister [Westinghouse Electric Corporation, 1984]. 


\section{Shield Plug}
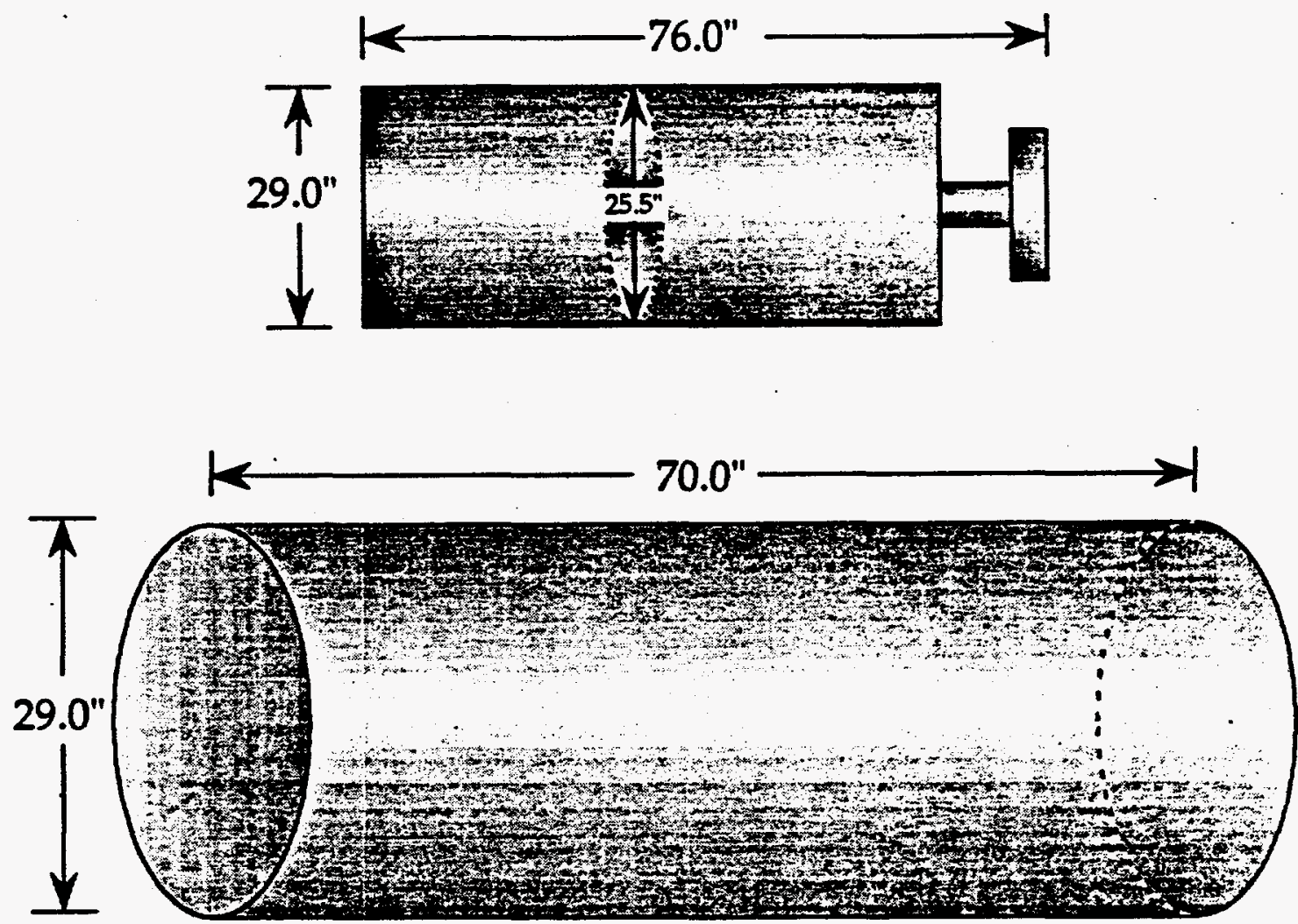

M94306.

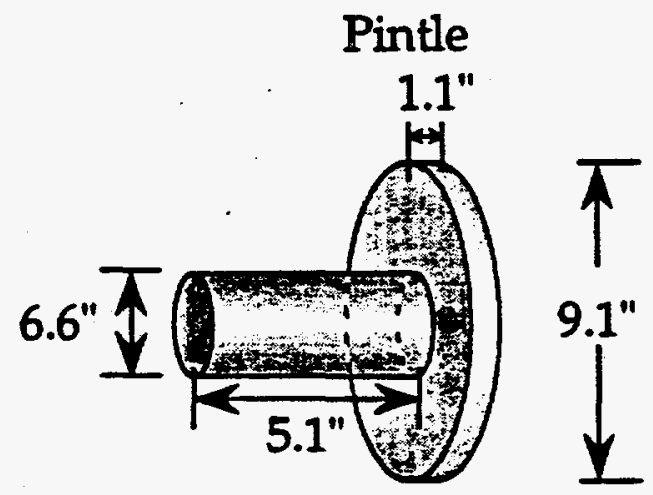

Note:

Drawing Not to Scale

- These are nominal estimates which support the inventory assessment for corrodible metals. 


\section{REFERENCES}

Rockwell International, 1984, "User's Manual for Remote-Handled Transuranic Waste Container," RHO-RE-MA-7, Rockwell Hanford Operations.

U.S. Department of Transportation, 1991, Title 49, Code of Federal Regulations, Part 173, “General Requirements for Shipping and Packaging."

Westinghouse Electric Corporation, 1984, Horizontal Emplacement and Retrieval Equipment Detailed Design Report, WTSD-TME-041, Rev. 0; Waste Technology Services Division, Westinghouse Electric Corporation, Madison, Pennsylvania, December 1984. 



\section{APPENDIX B}

\section{DISPOSAL RADIONUCLIDE INVENTORY}





\section{APPENDIX B}

DISPOSAL RADIONUCLIDE INVENTORY

Disposal Radionuclide Inventory

(Curies)

\begin{tabular}{|c|c|c|}
\hline Nuclide & Total CH & Total RH \\
\hline $\mathrm{Ac}-225$ & $2.03 E+00$ & 3.28E-01 \\
\hline Ac-227 & $6.55 \mathrm{E}-01$ & $1.52 \mathrm{E}-02$ \\
\hline Ac-228 & $5.27 \mathrm{E}-01$ & $4.08 \mathrm{E}-03$ \\
\hline $\mathrm{Ag}-109 \mathrm{M}$ & $4.85 \mathrm{E}+01$ & NR \\
\hline $\mathrm{Ag}-110$ & 5.61E-06 & $1.07 \mathrm{E}-05$ \\
\hline $\mathrm{Ag}-110 \mathrm{M}$ & $4.21 E-04$ & 8.06E-04 \\
\hline Am-241 & $2.23 E+05$ & $5.30 \mathrm{E}+02$ \\
\hline Am-242 & 4.93E-02 & NR \\
\hline Am-242M & $4.96 \mathrm{E}-02$ & NR \\
\hline Am-243 & $2.94 \mathrm{E}+01$ & $1.22 \mathrm{E}-02$ \\
\hline Am-245 & $9.07 \mathrm{E}-09$ & 2.52E-14 \\
\hline At-217 & $2.03 E+00$ & $3.28 \mathrm{E}-01$ \\
\hline $\mathrm{Ba}-137 \mathrm{M}$ & $5.03 E+03$ & $3.10 \mathrm{E}+05$ \\
\hline Bi-210 & $1.01 E+00$ & $4.09 \mathrm{E}-11$ \\
\hline $\mathrm{Bi}-211$ & 6.57E-01 & $1.46 \mathrm{E}-02$ \\
\hline Bi-212 & 2.77E+01 & $9.03 \mathrm{E}+00$ \\
\hline $\mathrm{Bi}-213$ & $2.03 E+00$ & 3.28E-01 \\
\hline $\mathrm{Bi}-214$ & $5.84 \mathrm{E}+00$ & $7.23 \mathrm{E}-10$ \\
\hline Bk-249 & $6.25 \mathrm{E}-04$ & $1.74 \mathrm{E}-09$ \\
\hline Bk-250 & $2.35 \mathrm{E}-06$ & NR \\
\hline C-14 & $1.83 \mathrm{E}+01$ & $1.51 \mathrm{E}+02$ \\
\hline Cd-109 & $4.85 \mathrm{E}+01$ & NR \\
\hline Cd-113M & 4.65E-05 & 2.36E-05 \\
\hline
\end{tabular}




\begin{tabular}{|c|c|c|}
\hline Nuclide & Total CH & Total RH \\
\hline $\mathrm{Ce}-144$ & $8.22 E+01$ & $5.58 \mathrm{E}+02$ \\
\hline Cf-249 & $1.56 \mathrm{E}+00$ & 8.11E-02 \\
\hline Cf-250 & $3.54 \mathrm{E}-01$ & NR \\
\hline Cf-251 & $3.93 \mathrm{E}-03$ & NR \\
\hline Cf-252 & $1.85 \mathrm{E}+02$ & $5.11 \mathrm{E}+01$ \\
\hline $\mathrm{Cm}-242$ & $1.48 \mathrm{E}-02$ & NR \\
\hline $\mathrm{Cm}-243$ & $1.33 \mathrm{E}+00$ & $2.01 E+03$ \\
\hline $\mathrm{Cm}-244$ & $5.40 \mathrm{E}+03$ & 1.07E+04 \\
\hline $\mathrm{Cm}-245$ & $5.16 \mathrm{E}+01$ & 1.32E-05 \\
\hline $\mathrm{Cm}-246$ & $1.10 \mathrm{E}-01$ & NR \\
\hline $\mathrm{Cm}-247$ & 2.98E-09 & NR \\
\hline $\mathrm{Cm}-248$ & $5.06 \mathrm{E}-02$ & 2.34E-03 \\
\hline Co-58 & $5.50 \mathrm{E}-05$ & 7.92E-07 \\
\hline $\mathrm{Co}-60$ & $1.53 \mathrm{E}+02$ & $1.08 \mathrm{E}+04$ \\
\hline$C_{r-51}$ & NR & $2.54 \mathrm{E}-31$ \\
\hline Cs-134 & $5.88 \mathrm{E}+00$ & $2.15 E+03$ \\
\hline Cs-135 & $7.90 \mathrm{E}-03$ & $4.58 \mathrm{E}-03$ \\
\hline Cs-137 & $5.32 \mathrm{E}+03$ & $3.28 \mathrm{E}+05$ \\
\hline Es-254 & 2.35E-06 & NR \\
\hline Eu-150 & 3.65E-05 & NR \\
\hline Eu-152 & $7.41 \mathrm{E}+00$ & $5.28 \mathrm{E}+04$ \\
\hline Eu-154 & $3.05 \mathrm{E}+01$ & $2.76 \mathrm{E}+04$ \\
\hline Eu-155 & $4.14 \mathrm{E}+01$ & $6.78 \mathrm{E}+03$ \\
\hline $\mathrm{Fe}-55$ & $3.296 \mathrm{E}-05$ & $1.44 \mathrm{E}+01$ \\
\hline Fe-59 & $1.96 \mathrm{E}-02$ & 4.04E-19 \\
\hline Fr-221 & $2.03 E+00$ & $3.28 \mathrm{E}-01$ \\
\hline Fr-223 & $9.04 \mathrm{E}-03$ & $2.10 \mathrm{E}-04$ \\
\hline H-3 & $9.64 \mathrm{E}-01$ & $8.23 E+01$ \\
\hline
\end{tabular}




\begin{tabular}{|l|c|c|}
\hline \multicolumn{1}{|c|}{ Nuclide } & Total CH & Total RH \\
\hline $\mathrm{I}-129$ & $1.28 \mathrm{E}-09$ & NR \\
\hline $\mathrm{Kr}-85$ & $2.24 \mathrm{E}-01$ & $9.58 \mathrm{E}+01$ \\
\hline $\mathrm{Mn}-54$ & $1.12 \mathrm{E}-02$ & $2.76 \mathrm{E}+00$ \\
\hline $\mathrm{Nb}-95$ & $4.96 \mathrm{E}-01$ & $9.90 \mathrm{E}+00$ \\
\hline $\mathrm{Nb}-95 \mathrm{M}$ & $1.66 \mathrm{E}-03$ & $3.41 \mathrm{E}-02$ \\
\hline $\mathrm{Ni}-59$ & $3.38 \mathrm{E}-03$ & NR \\
\hline $\mathrm{Ni}-63$ & $4.19 \mathrm{E}-01$ & $5.03 \mathrm{E}+01$ \\
\hline $\mathrm{Np}-237$ & $8.82 \mathrm{E}+01$ & $1.18 \mathrm{E}-02$ \\
\hline $\mathrm{Np}-238$ & $2.48 \mathrm{E}-04$ & $\mathrm{NR}$ \\
\hline $\mathrm{Np}-239$ & $2.94 \mathrm{E}+01$ & $1.22 \mathrm{E}-02$ \\
\hline $\mathrm{Np}-240$ & $1.10 \mathrm{E}-09$ & $1.78 \mathrm{E}-13$ \\
\hline $\mathrm{Np}-240 \mathrm{M}$ & $1.00 \mathrm{E}-06$ & $1.62 \mathrm{E}-10$ \\
\hline $\mathrm{Pa}-231$ & $4.08 \mathrm{E}-03$ & $1.78 \mathrm{E}-01$ \\
\hline $\mathrm{Pa}-233$ & $3.32 \mathrm{E}+01$ & $1.18 \mathrm{E}-02$ \\
\hline $\mathrm{Pa}-234$ & $2.44 \mathrm{E}-02$ & $1.70 \mathrm{E}-02$ \\
\hline $\mathrm{Pa}-234 \mathrm{M}$ & $1.88 \mathrm{E}+01$ & $1.31 \mathrm{E}+01$ \\
\hline $\mathrm{Pb}-209$ & $2.03 \mathrm{E}+00$ & $3.28 \mathrm{E}-01$ \\
\hline $\mathrm{Pb}-210$ & $1.01 \mathrm{E}+00$ & $4.09 \mathrm{E}-11$ \\
\hline $\mathrm{Pb}-211$ & $6.57 \mathrm{E}-01$ & $1.46 \mathrm{E}-02$ \\
\hline $\mathrm{Pb}-212$ & $2.77 \mathrm{E}+01$ & $9.03 \mathrm{E}+00$ \\
\hline $\mathrm{Pb}-214$ & $5.84 \mathrm{E}+00$ & $7.23 \mathrm{E}-10$ \\
\hline $\mathrm{Pd}-107$ & $1.17 \mathrm{E}-03$ & $6.77 \mathrm{E}-04$ \\
\hline $\mathrm{Pm}-147$ & $1.26 \mathrm{E}+03$ & $4.10 \mathrm{E}+03$ \\
\hline $\mathrm{Po}-210$ & $8.92 \mathrm{E}-01$ & $3.05 \mathrm{E}-11$ \\
\hline $\mathrm{Po}-211$ & $1.79 \mathrm{E}-03$ & $3.98 \mathrm{E}-05$ \\
\hline $\mathrm{Po}-212$ & $1.78 \mathrm{E}+01$ & $5.78 \mathrm{E}+00$ \\
\hline $\mathrm{Po}-213$ & $5.84 \mathrm{E}+00$ & $3.21 \mathrm{E}-01$ \\
\hline $\mathrm{Po}-214$ & & $7.23 \mathrm{E}-10$ \\
\hline & & \\
\hline & & \\
\hline
\end{tabular}




\begin{tabular}{|l|c|c|}
\hline \multicolumn{1}{|c|}{ Nuclide } & Total CH & Total RH \\
\hline Po-215 & $6.57 \mathrm{E}-01$ & $1.46 \mathrm{E}-02$ \\
\hline Po-216 & $2.77 \mathrm{E}+01$ & $9.03 \mathrm{E}+00$ \\
\hline Po-218 & $5.84 \mathrm{E}+00$ & $7.23 \mathrm{E}-10$ \\
\hline Pr-144 & $8.22 \mathrm{E}+01$ & $5.58 \mathrm{E}+02$ \\
\hline Pu-236 & $1.69 \mathrm{E}-02$ & NR \\
\hline Pu-238 & $1.89 \mathrm{E}+06$ & $3.53 \mathrm{E}+03$ \\
\hline Pu-239 & $3.85 \mathrm{E}+05$ & $6.41 \mathrm{E}+03$ \\
\hline Pu-240 & $7.22 \mathrm{E}+04$ & $1.74 \mathrm{E}+02$ \\
\hline Pu-241 & $1.01 \mathrm{E}+06$ & $9.06 \mathrm{E}+02$ \\
\hline Pu-242 & $1.27 \mathrm{E}+03$ & $1.48 \mathrm{E}-02$ \\
\hline Pu-243 & $2.98 \mathrm{E}-09$ & NR \\
\hline Pu-244 & $1.00 \mathrm{E}-06$ & $1.62 \mathrm{E}-10$ \\
\hline Ra-223 & $6.57 \mathrm{E}-01$ & $1.46 \mathrm{E}-02$ \\
\hline Ra-224 & $2.77 \mathrm{E}+01$ & $9.03 \mathrm{E}+00$ \\
\hline Ra-225 & $2.04 \mathrm{E}+00$ & $3.31 \mathrm{E}-01$ \\
\hline Ra-226 & $5.84 \mathrm{E}+00$ & $7.23 \mathrm{E}-10$ \\
\hline Ra-228 & $5.27 \mathrm{E}-01$ & $4.08 \mathrm{E}-03$ \\
\hline Rh-106 & $4.02 \mathrm{E}+01$ & $8.42 \mathrm{E}+02$ \\
\hline Rn-219 & $6.57 \mathrm{E}-01$ & $1.46 \mathrm{E}-02$ \\
\hline Rn-220 & $2.77 \mathrm{E}+01$ & $9.03 \mathrm{E}+00$ \\
\hline Rn-222 & $5.84 \mathrm{E}+00$ & $7.23 \mathrm{E}-10$ \\
\hline Ru-106 & $4.02 \mathrm{E}+01$ & $8.42 \mathrm{E}+02$ \\
\hline Sb-125 & $1.58 \mathrm{E}+01$ & $2.46 \mathrm{E}+03$ \\
\hline Sb-126 & $2.13 \mathrm{E}-03$ & $1.23 \mathrm{E}-03$ \\
\hline Sb-126M & $1.52 \mathrm{E}-02$ & $8.80 \mathrm{E}-03$ \\
\hline Se-79 & $6.86 \mathrm{E}-03$ & $3.97 \mathrm{E}-03$ \\
\hline Sm-151 & & $1.42 \mathrm{E}+01$ \\
\hline Sn-119M & & $1.37 \mathrm{E}-02$ \\
\hline & & \\
\hline & & \\
\hline
\end{tabular}




\begin{tabular}{|l|c|c|}
\hline \multicolumn{1}{|c|}{ Nuclide } & Total CH & Total RH \\
\hline Sn-121M & $4.82 \mathrm{E}-01$ & $2.69 \mathrm{E}-01$ \\
\hline Sn-126 & $1.52 \mathrm{E}-02$ & $8.80 \mathrm{E}-03$ \\
\hline Sr-90 & $4.07 \mathrm{E}+03$ & $6.68 \mathrm{E}+05$ \\
\hline Ta-182 & NR & $1.72 \mathrm{E}-04$ \\
\hline Tc-99 & $2.46 \mathrm{E}+01$ & $2.28 \mathrm{E}-01$ \\
\hline Te-125M & $6.55 \mathrm{E}-04$ & $1.01 \mathrm{E}+03$ \\
\hline Te-127 & $3.07 \mathrm{E}-02$ & $1.13 \mathrm{E}-01$ \\
\hline Te-127M & $3.15 \mathrm{E}-02$ & $1.15 \mathrm{E}-01$ \\
\hline Th-227 & $6.56 \mathrm{E}-01$ & $1.48 \mathrm{E}-02$ \\
\hline Th-228 & $2.77 \mathrm{E}+01$ & $9.04 \mathrm{E}+00$ \\
\hline Th-229 & $2.05 \mathrm{E}+00$ & $3.36 \mathrm{E}-01$ \\
\hline Th-230 & $4.90 \mathrm{E}-02$ & $8.79 \mathrm{E}-07$ \\
\hline Th-231 & $2.88 \mathrm{E}+00$ & $2.21 \mathrm{E}+03$ \\
\hline Th-232 & $6.07 \mathrm{E}-01$ & $7.09 \mathrm{E}-03$ \\
\hline Th-234 & $1.88 \mathrm{E}+01$ & $1.31 \mathrm{E}+01$ \\
\hline Tl-207 & $6.56 \mathrm{E}-01$ & $1.45 \mathrm{E}-02$ \\
\hline Tl-208 & $9.96 \mathrm{E}+00$ & $3.24 \mathrm{E}+00$ \\
\hline Tl-209 & $4.39 \mathrm{E}-02$ & $7.08 \mathrm{E}-03$ \\
\hline Tl-210 & $1.23 \mathrm{E}-03$ & $1.52 \mathrm{E}-13$ \\
\hline U-232 & $2.63 \mathrm{E}+01$ & $1.16 \mathrm{E}+01$ \\
\hline U-233 & $1.38 \mathrm{E}+03$ & $8.57 \mathrm{E}+02$ \\
\hline U-234 & $2.50 \mathrm{E}+02$ & $4.18 \mathrm{E}-02$ \\
\hline U-235 & $2.88 \mathrm{E}+00$ & $5.66 \mathrm{E}+00$ \\
\hline U-236 & $1.34 \mathrm{E}-01$ & $4.11 \mathrm{E}-05$ \\
\hline U-237 & $2.47 \mathrm{E}+01$ & $2.22 \mathrm{E}-02$ \\
\hline U-238 & $1.07 \mathrm{E}+01$ & $1.62 \mathrm{E}-10$ \\
\hline U-240 & $6.68 \mathrm{E}+05$ \\
\hline Y-90 & & \\
\hline & & 03 \\
\hline
\end{tabular}




\begin{tabular}{|l|c|c|}
\hline \multicolumn{1}{|c|}{ Nuclide } & Total CH & Total RH \\
\hline $\mathrm{Zn}-65$ & $1.21 \mathrm{E}-08$ &. $\mathrm{NR}$ \\
\hline $\mathrm{Zr}-93$ & $8.87 \mathrm{E}-02$ & $5.14 \mathrm{E}-02$ \\
\hline $\mathrm{Zr}-95$ & $2.24 \mathrm{E}-01$ & $4.60 \mathrm{E}+00$ \\
\hline Total & $3.60 \mathrm{E}+06$ & $2.11 \mathrm{E}+06$ \\
\hline
\end{tabular}

NR $=$ Not reported by sites .

Source: DOE, 1995. 


\section{REFERENCES}

Sandia WIPP Project, 1992, Preliminary Performance Assessment for the Waste Isolation Pilot Plant, December 1992, SAND92-0700, December 1992.

U.S. Department of Energy, 1995, Waste Isolation Pilot Plant Transuranic Waste Baseline Inventory Report, Revision 1, COA-94-1005, February 1995. 



\section{APPENDIX C}

\section{ORIGEN MODEL RESULTS FOR RADIONUCLIDE ACTIVITY, 0-10,000 YEARS, AND RADIONUCLIDE DECAY SERIES}





\section{APPENDIX C \\ ORIGEN MODEL RESULTS FOR RADIONUCLDE ACTIVTTY, 0-10,000 YEARS, AND RADIONUCLIDE DECAY SERIES}

The ORIGEN computer model developed at Oak Ridge National Laboratory (ORIGEN2 for personal computers and ORIGEN-S for UNIX workstations) calculates the buildup, decay, and processing of radioactive materials [1]. ORIGEN simulates nuclear fuel cycles and calculates nuclide compositions and characteristics of materials. One of the principal uses of ORIGEN is to project the composition and characteristics of radioactive wastes for regulatory purposes [2].

ORIGEN solves the following nonhomogeneous first-order ordinary differential equation using a matrix exponential method [2]:

$$
\frac{d X_{i}}{d t}=\sum_{j=1}^{v} 1_{i j} \lambda_{j} X_{j}+\phi \sum_{k=1}^{v} f_{k j} \sigma_{k} X_{k}-\left(\lambda_{i}+\phi \sigma_{i}+r_{i}\right) X_{i}+F_{i}, i=1, \ldots, N
$$

where,

$X_{i}=$ atom density of nuclide $I$

$\mathrm{N}=$ number of nuclides

$\mathbf{l}_{\mathrm{ij}}=$ fraction of radioactive disintegration by other nuclides which forms species I

$\lambda_{i}=$ radioactive decay constant

$\phi=$ position- and energy-averaged neutron flux

$f_{2}=$ Fraction of neutron absorption by other nuclides leading to formation of species I

$\sigma_{k}=$ spectrum-averaged neutron absorption cross-section of nuclide $k$

$\mathbf{r}_{\mathbf{i}}=$ continuous removal rate of nuclide I

$F_{i}=$ continuous feed rate of nuclide $I$ 
For radioactive decay calculations without irradiation of the materials, such as those needed to project the composition of radioactive waste in the future, this equation simply reduces to the Bateman equation for each nuclide present in the initial inventory:

$$
\frac{d X_{i}}{d t}=\sum_{j=1}^{v} 1_{i j} \lambda_{j} X_{j}-\lambda_{i} X_{i}, i=1, \ldots, N
$$

ORIGEN obtains data from the decay library regarding the half-lives and decay branching fractions of the radionuclides listed in the input file. The code then calculates the daughter of each nuclear decay or transformation and the rate at which the accumulation occurs. This information is temporarily stored in an array and used to obtain all parents of a given daughter nuclide [2]. The user directs the length of time that the decay is to be observed by using the DEC command card in the input file. As many as 150 decay time intervals can be specified depending on other commands the user wishes to implement in any given ORIGEN run. The final output yields the concentrations of the parent and daughter nuclides at the end of each time interval specified by the user. 


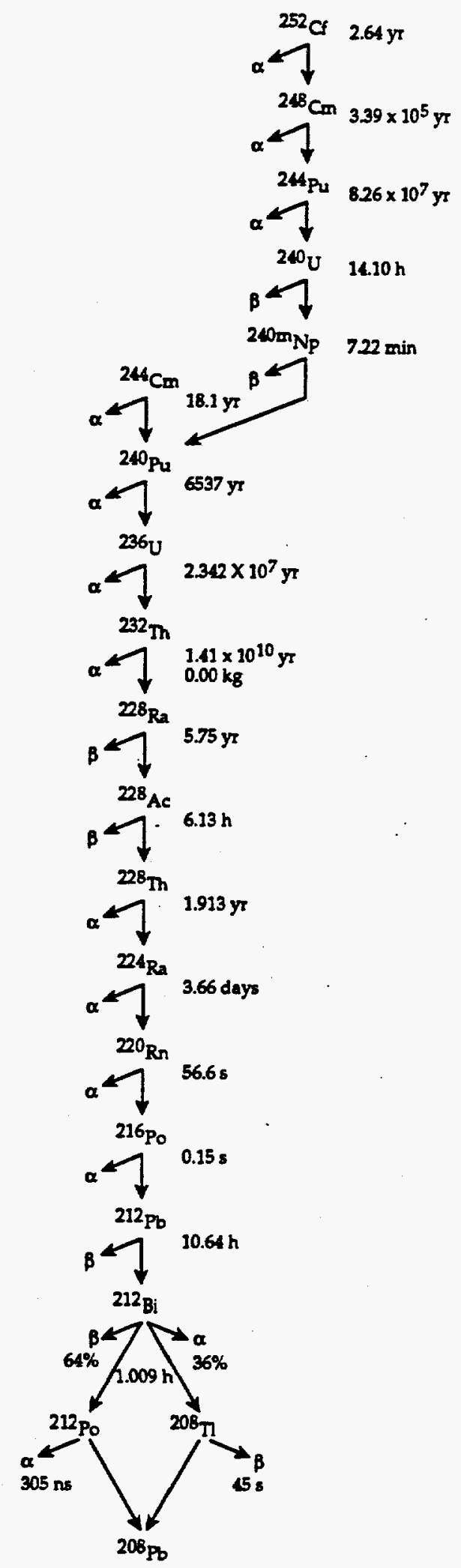

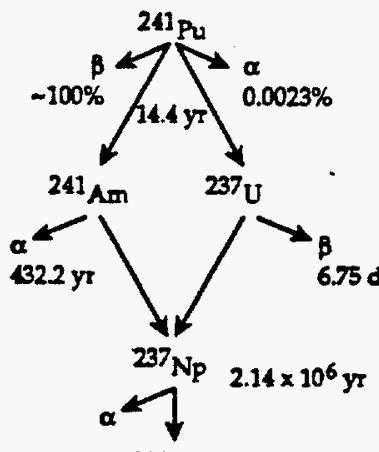

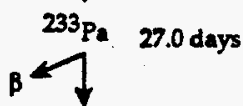

$a^{233} \mathrm{U} 1.585 \times 10^{5} \mathrm{yr}$

${ }^{229}$ Th $7340 \times 10^{3} \mathrm{yr}$

225Ra 14.8 days

B

$225_{A C}$

$\alpha$

${ }^{22} 1_{\mathrm{Ft}} \quad 4.8 \mathrm{~min}$

$\alpha-7$

217 At $32.3 \mathrm{~ms}$

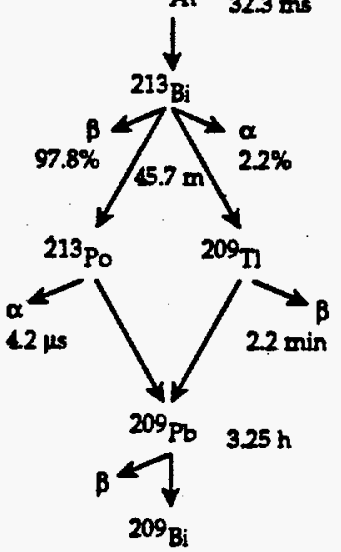

MDes31122rev

Figure C-1. Decay Series for $\mathrm{CH}$ and $\mathrm{RH}$ Radionuclides

[Source: Sandia WIPP Project, 1992] 

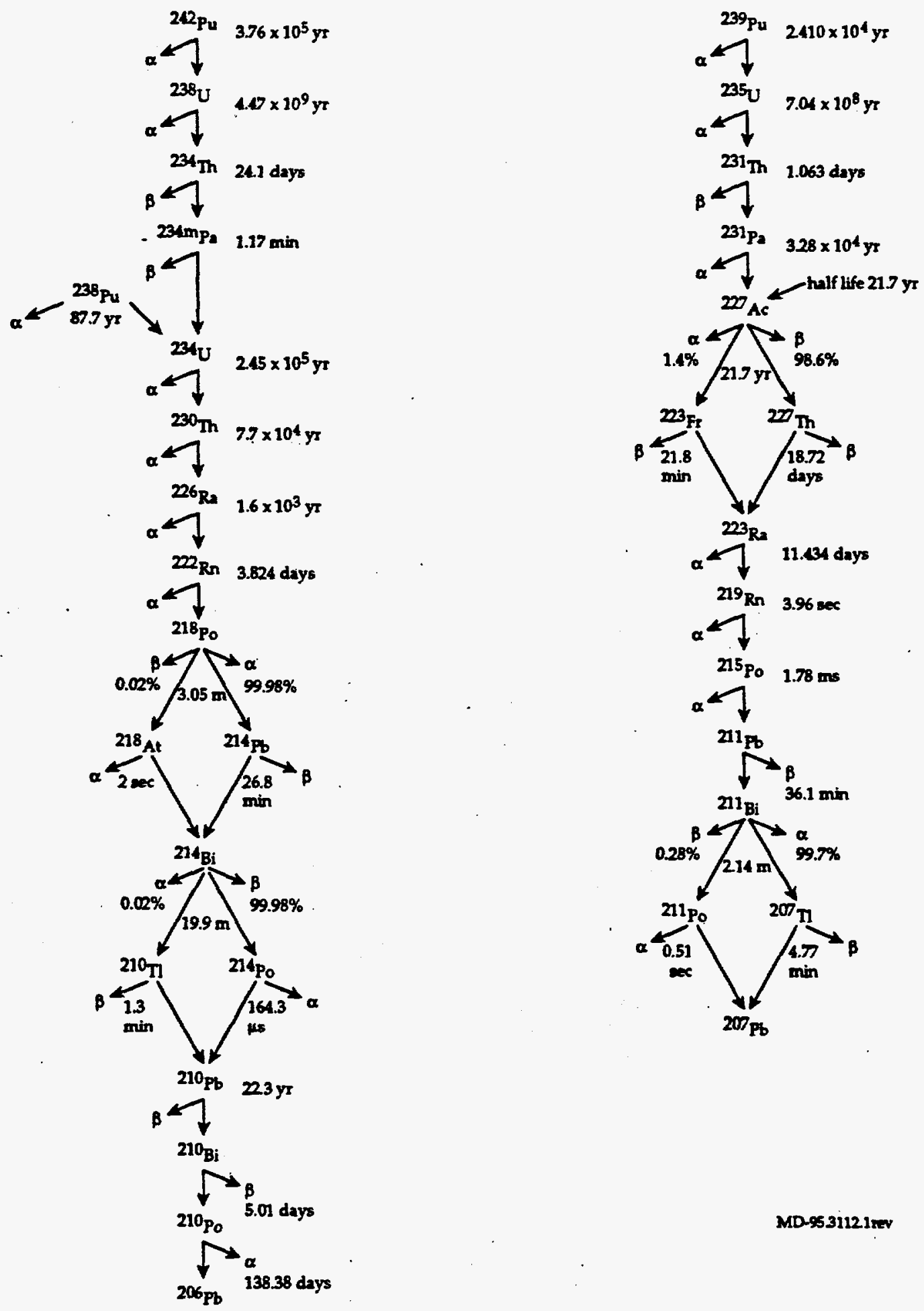

Figure C-1. Decay Series for $\mathrm{CH}$ and $\mathrm{RH}$ Radionuclides (continued) [Source: Sandia WIPP Project, 1992] 

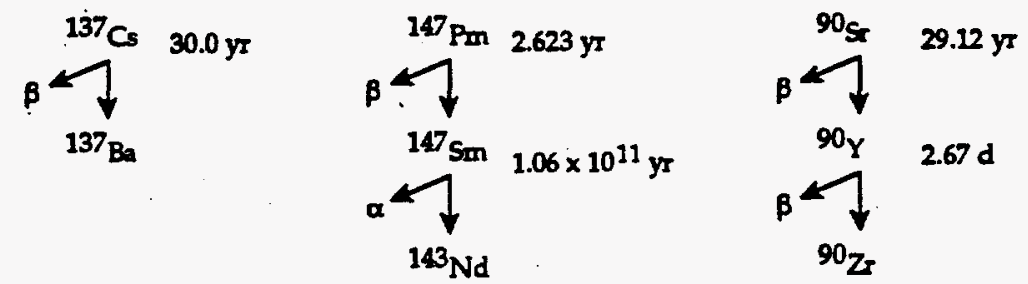

MD-95.3112.3rev

Figure C-1. Decay Series for $\mathrm{CH}$ and $\mathrm{RH}$ Radionuclides (continued) [Source: Sandia WIPP Project, 1992] 


\section{REFERENCES}

1. Croff, A. G., "A User's Manual for the ORIGEN2 Code," ORNL/TM-7175, Oak Ridge National Laboratory, July 1980.

2. Croff, A. G., "ORIGEN2: A Versatile Computer Code for Calculating the Nuclide Compositions and Characteristics of Nuclear Materials," Nuclear Technology, Vol. 62, pp. 335-352, November 1983. 


\begin{tabular}{|c|c|c|c|c|c|c|c|c|c|c|c|}
\hline Isotope & Initial & $100.0 \mathrm{yr}$ & $200.0 \mathrm{yr}$ & $300.0 \mathrm{yr}$ & $400.0 \mathrm{yr}$ & $500.0 \mathrm{yr}$ & $600.0 \mathrm{yr}$ & $700.0 \mathrm{yr}$ & $800.0 \mathrm{yr}$ & $900.0 \mathrm{yr}$ & 1000.0 yr \\
\hline Ac225 & $2.03 E+01$ & $1.41 E+02$ & $2.61 E+02$ & $3.79 E+02$ & $4.97 E+02$ & $6.13 E+02$ & $7.28 E+02$ & $8.42 E+02$ & $9.55 E+02$ & 1.07E+03 & $1.18 E+03$ \\
\hline Ac227 & $6.55 E-00$ & 3.53E-01 & $1.56 E-01$ & 2.07E-01 & $2.70 E-01$ & 3.33E-01 & $3.98 E-01$ & $4.63 \mathrm{E}-01$ & $5.28 \mathrm{E}-01$ & 5.94E-01 & $6.61 E-01$ \\
\hline Ac228 & $5.27 E-00$ & $6.07 \mathrm{E}-00$ & $6.07 E-00$ & $6.07 E-00$ & $6.07 E-00$ & 6.07E-00 & $6.07 E-00$ & $6.07 E-00$ & $6.07 \mathrm{E}-00$ & $6.07 E-00$ & $6.07 E-00$ \\
\hline Ag109m & $4.85 E+02$ & $0.00 E+01$ & $0.00 E+01$ & $0.00 \mathrm{E}+01$ & $0.00 E+01$ & $0.00 E+01$ & $0.00 E+01$ & $0.00 E+01$ & $0.00 E+01$ & $0.00 E+01$ & $0.00 \mathrm{E}+01$ \\
\hline Ag110 & $5.61 \mathrm{E}-05$ & $0.00 E+01$ & $0.00 E+01$ & $0.00 E+01$ & $0.00 E+01$ & $0.00 E+01$ & $0.00 E+01$ & $0.00 E+01$ & $0.00 E+01$ & $0.00 E+01$ & $0.00 E+01$ \\
\hline $\mathrm{Ag} 110 \mathrm{~m}$ & $4.21 \mathrm{E}-03$ & $0.00 E+01$ & $0.00 E+01$ & $0.00 E+01$ & $0.00 E+01$ & $0.00 E+01$ & $0.00 E+01$ & $0.00 E+01$ & $0.00 E+01$ & $0.00 E+01$ & $0.00 E+01$ \\
\hline Am241 & $2.23 E+06$ & $2.19 E+06$ & $1.87 E+06$ & $1.59 E+06$ & $1.36 E+06$ & $1.16 E+06$ & $9.85 E+05$ & $8.39 E+05$ & $7.15 E+05$ & $6.09 E+05$ & $5.19 E+05$ \\
\hline Am242 & $4.93 \mathrm{E}-0.1$ & $3.02 \mathrm{E}-01$ & $1.85 E-01$ & $1.13 \mathrm{E}-01$ & $6.91 \mathrm{E}-02$ & $4.23 E-02$ & $2.59 E-02$ & $1.58 \mathrm{E}-02$ & $9.67 \mathrm{E}-03$ & $5.92 \mathrm{E}-03$ & $3.62 E-03$ \\
\hline Am242m & $4.96 \mathrm{E}-01$ & $3.03 \mathrm{E}-01$ & $1.86 \mathrm{E}-01$ & 1.13E-01 & $6.94 \mathrm{E}-02$ & $4.25 \mathrm{E}-02$ & $2.60 \mathrm{E}-02$ & $1.59 \mathrm{E}-02$ & $9.72 \mathrm{E}-03$ & $5.94 \mathrm{E}-03$ & $3.64 \mathrm{E}-03$ \\
\hline Am243 & $2.94 E+02$ & $2.91 E+02$ & $2.89 E+02$ & $2.86 E+02$ & $2.83 E+02$ & $2.80 E+02$ & $2.78 E+02$ & $2.75 E+02$ & $2.73 E+02$ & $2.70 E+02$ & $2.68 E+02$ \\
\hline Am245 & $9.07 \mathrm{E}-08$ & $0.00 E+01$ & $0.00 E+01$ & $0.00 E+01$ & $0.00 E+01$ & $0.00 E+01$ & $0.00 E+01$ & $0.00 E+01$ & $0.00 E+01$ & $0.00 E+01$ & $0.00 E+01$ \\
\hline At217 & $2.03 E+01$ & $1.41 E+02$ & $2.61 E+02$ & $3.79 \mathrm{E}+02$ & $4.97 E+02$ & $6.13 E+02$ & $7.28 E+02$ & $8.42 E+02$ & $9.55 E+02$ & $1.07 E+03$ & $1.18 E+03$ \\
\hline Ba137m & $5.03 E+04$ & $4.98 E+03$ & & $4.90 E+01$ & & $4.82 \mathrm{E}-01$ & $4.78 \mathrm{E}-02$ & $4.74 E-03$ & $4.71 \mathrm{E}-04$ & & \\
\hline$B i 210$ & $1.01 E+01$ & $5.45 E+01$ & $5.45 E+01$ & $5.28 E+01$ & $5.14 E+01$ & $5.05 E+01$ & $4.99 \mathrm{E}+01$ & $4.97 E+01$ & $4.98 E+01$ & $5.03 E+01$ & $5.12 E+01$ \\
\hline$\overline{B i 211}$ & $6.57 \mathrm{E}-00$ & $3.54 \mathrm{E}-01$ & $1.56 \mathrm{E}-01$ & 2.07E-01 & $2.70 E-01$ & $3.33 \mathrm{E}-01$ & $3.98 \mathrm{E}-01$ & $4.63 E-01$ & $5.28 \mathrm{E}-01$ & $5.94 \mathrm{E}-01$ & $6.61 \mathrm{E}-01$ \\
\hline $\mathrm{Bi212}$ & $2.77 E+02$ & $1.06 E+02$ & +01 & $1.98 E+01$ & $1.12 E+01$ & $7.96 \mathrm{E}-00$ & $6.77 \mathrm{E}-00$ & $6.33 \mathrm{E}-00$ & $E-00$ & $E-00$ & $6.08 \mathrm{E}-00$ \\
\hline$B i 213$ & $2.03 E+01$ & $1.41 E+02$ & $2.61 E+02$ & $3.79 E+02$ & $4.96 E+02$ & $6.13 E+02$ & $7.28 E+02$ & $8.42 E+02$ & $9.55 E+02$ & $1.07 E+03$ & $E+03$ \\
\hline Bi214 & $5.84 E+01$ & $5.60 E+01$ & $5.40 E+01$ & $5.23 E+01$ & $5.11 E+01$ & $5.02 E+01$ & $4.98 E+01$ & $4.97 E+01$ & $5.00 \mathrm{E}+01$ & $5.06 E+01$ & $5.15 E+01$ \\
\hline Bk249 & $6.25 E-03$ & $0.00 E+01$ & $E+01$ & $0.00 E+01$ & +01 & $E+01$ & $E+01$ & $E+01$ & $E+01$ & $E+01$ & $0 E+01$ \\
\hline Bk250 & $2.35 E-05$ & $E+01$ & +01 & $E+01$ & +01 & $E+01$ & $E+01$ & $E+01$ & $E+01$ & $E+01$ & $E+01$ \\
\hline C 14 & $1.83 E+02$ & $1.81 E+02$ & $1.79 E+02$ & $1.76 \mathrm{E}+02$ & $1.74 E+02$ & $1.72 E+02$ & $1.70 E+02$ & $1.68 E+02$ & $1.66 \mathrm{E}+02$ & $1.64 E+02$ & $1.62 \mathrm{E}+02$ \\
\hline Cd109 & $4.85 E+02$ & $7.71 E-22$ & $0.00 E+01$ & $0.00 E+01$ & $0.00 E+01$ & $0.00 E+01$ & $0.00 E+01$ & $0 \mathrm{E}+01$ & $0.00 E+01$ & $0.00 E+01$ & $0.00 \mathrm{E}+01$ \\
\hline Cd113 & $0.00 \mathrm{E}+01$ & $9.80 \mathrm{E}-22$ & $9.87 E-22$ & $9.87 \mathrm{E}-22$ & $9.87 E-22$ & $9.87 \mathrm{E}-22$ & $9.87 E-22$ & $\overline{7 E-22}$ & $9.87 E-22$ & $E-22$ & $17 E-22$ \\
\hline Cd113m & $4.65 E-04$ & $3.41 E-06$ & $2.50 \mathrm{E}-08$ & $1.83 \mathrm{E}-10$ & $1.34 \mathrm{E}-12$ & $9.83 E-15$ & $7.21 \mathrm{E}-17$ & $5.28 \mathrm{E}-19$ & $3.87 \mathrm{E}-21$ & $2.84 E-23$ & $2.08 E-25$ \\
\hline Ce144 & $8.22 E+02$ & $0.00 E+01$ & $0.00 E+01$ & $0.00 E+01$ & $0.00 E+01$ & $0.00 E+01$ & $0.00 E+01$ & $0.00 E+01$ & $0.00 E+01$ & $0.00 E+01$ & $0.00 E+01$ \\
\hline$C+249$ & $1.56 E+01$ & $1.28 E+01$ & $1.05 E+01$ & $8.62 \mathrm{E}-00$ & 7.07E-00 & $5.80 \mathrm{E}-00$ & $4.76 \mathrm{E}-00$ & $3.91 \mathrm{E}-00$ & $3.21 \mathrm{E}-00$ & $2.63 E-00$ & $2.16 E-00$ \\
\hline C 250 & $3.54 E-00$ & $1,77 \mathrm{E}-02$ & $8.83 E-05$ & $4.41 E-07$ & $2.20 \mathrm{E}-09$ & $1.10 \mathrm{E}-11$ & $5.50 \mathrm{E}-14$ & $2.75 \mathrm{E}-16$ & $1.37 \mathrm{E}-18$ & $6.85 E-21$ & $3.42 \mathrm{E}-23$ \\
\hline C2251 & $3.93 E-02$ & $3.64 \mathrm{E}-02$ & $3.37 \mathrm{E}-02$ & $3.12 E-02$ & $2.89 \mathrm{E}-02$ & $2.67 \mathrm{E}-02$ & $2.47 E-02$ & $2.29 \mathrm{E}-02$ & $2.12 \mathrm{E}-02$ & $1.96 \mathrm{E}-02$ & $1.82 \mathrm{E}-02$ \\
\hline C 252 & $1.85 E+03$ & $7.68 \mathrm{E}-09$ & $3: 19 \mathrm{E}-20$ & $2.28 E-31$ & & $0.00 \mathrm{E}+01$ & $0.00 E+01$ & $0.00 E+01$ & $0.00 \mathrm{E}+01$ & $0.00 E+01$ & $0.00 \mathrm{E}+01$ \\
\hline $\mathrm{Cm} 242$ & $1.48 E-01$ & $2.50 \mathrm{E}-01$ & $1.53 E-01$ & $9.34 E-02$ & $5.72 \mathrm{E}-02$ & $3.50 \mathrm{E}-02$ & $2.14 \mathrm{E}-02$ & $\mathrm{E}-02$ & E-03 & -03 & $E-03$ \\
\hline $\mathrm{Cm} 243$ & $1.33 E+01$ & $1.17 E-00$ & $1.03 \mathrm{E}-01$ & $9.01 \mathrm{E}-03$ & $7.92 \mathrm{E}-04$ & $6.95 \mathrm{E}-05$ & $6.11 E-06$ & 5.37E-07 & $4.71 \mathrm{E}-08$ & $4.14 E-09$ & $3.64 \mathrm{E}-10$ \\
\hline $\mathrm{Cm} 244$ & $5.40 E+04$ & $1.17 E+03$ & $2.55 E+01$ & $5.53 \mathrm{E}-01$ & $1.20 \mathrm{E}-02$ & $2.61 E-04$ & $5.66 \mathrm{E}-06$ & $1.23 \mathrm{E}-07$ & 2.67E-09 & $5.79 \mathrm{E}-11$ & $1.26 \mathrm{E}-12$ \\
\hline $\mathrm{Cm} 245$ & $5.16 E+02$ & $5.12 E+02$ & $5.08 E+02$ & $5.04 E+02$ & $5.00 E+02$ & $4.96 E+02$ & $4.92 E+02$ & $4.88 E+02$ & $4.84 E+02$ & $4.80 E+02$ & $4.76 E+02$ \\
\hline Cm246 & $1.10 \mathrm{E}-00$ & $1.09 \mathrm{E}-00$ & $1.08 \mathrm{E}-00$ & $1.06 \mathrm{E}-00$ & & $1.03 E-00$ & $1.02 E-00$ & $1.00 E-00$ & $9.87 E-01$ & $9.73 E-01$ & $9.59 \mathrm{E}-01$ \\
\hline $\mathrm{Cm} 247$ & $2.98 \mathrm{E}-08$ & $1.94 E-07$ & $3.45 E-07$ & $4.86 E-07$ & $6.16 \mathrm{E}-07$ & $7.36 \mathrm{E}-07$ & $8.48 \mathrm{E}-07$ & $9.51 \mathrm{E}-07$ & $1.05 E-06$ & $1.13 \mathrm{E}-06$ & $1.22 \mathrm{E}-06$ \\
\hline $\mathrm{Cm} 248$ & $5.06 \mathrm{E}-01$ & $5.20 \mathrm{E}-01$ & $5.20 \mathrm{E}-01$ & $5.20 \mathrm{E}-01$ & $5.20 \mathrm{E}-01$ & $5.19 \mathrm{E}-01$ & $5.19 \mathrm{E}-01$ & $5.19 E-01$ & $5.19 E-01$ & $5.19 \mathrm{E}-01$ & $5.19 \mathrm{E}-01$ \\
\hline Co 58 & $5.50 \mathrm{E}-04$ & $0.00 E+01$ & $0.00 E+01$ & $0.00 E+01$ & $0.00 E+01$ & $0.00 E+01$ & $0.00 E+01$ & $0.00 E+01$ & $0.00 E+01$ & $0.00 E+01$ & $0.00 E+01$ \\
\hline Co 60 & $1.53 E+03$ & $2.96 \mathrm{E}-03$ & $5.74 E-09$ & $1.11 \mathrm{E}-14$ & $2.15 E-20$ & $4.17 \mathrm{E}-26$ & $0.00 E+01$ & $0.00 E+01$ & $0.00 E+01$ & $0.00 E+01$ & $0.00 \mathrm{E}+01$ \\
\hline
\end{tabular}




\begin{tabular}{|c|c|c|c|c|c|c|c|c|c|}
\hline \multicolumn{8}{|c|}{ WIPP CH TRU WASTE STUDY -DATA FROM WIPP BIR REVISION 1} & \multicolumn{2}{|c|}{ UNITS: Curies } \\
\hline Isotope & $2000.0 \mathrm{yr}$ & $3000.0 \mathrm{yr}$ & $\$ 000.0 \mathrm{yr}$ & $5000.0 \mathrm{yr}$ & $8000.0 \mathrm{yr}$ & $7000.0 \mathrm{yr}$ & $8000.0 \mathrm{yr}$ & $8000.0 \mathrm{yr}$ & 10000.0 \\
\hline Ac225 & $2.23 E+03$ & $3.20 \mathrm{E}+03$ & $4.07 E+03$ & $4.87 E+03$ & $5.60 E+03$ & $6.26 E+03$ & $6.86 \mathrm{E}+03$ & $7.41 E+03$ & $7.90 E+03$ \\
\hline & & 15E-00 & $2.98 \mathrm{E}-00$ & 00 & 4.78E-00 & $5.75 E-00$ & $6.77 \mathrm{E}-00$ & $7.83 E-00$ & $=00$ \\
\hline Ac228 & 6.07E-00 & 6.07E-00 & 6.07E-00 & 6.07E-00 & 6.07E-00 & & & $.07 E-00$ & \\
\hline & $0.00 E+01$ & $0.00 E+01$ & $0.00 E+01$ & $0.00 E+01$ & $0.00 E+01$ & $0.00 E+01$ & & & \\
\hline & & $0.00 E+01$ & $0.00 E+01$ & $0.00 E+01$ & $0.00 E+01$ & $0.00 E+01$ & $0.00 E+01$ & $0.00 E+01$ & $0.00 E+01$ \\
\hline & & & & & $0.00 E+01$ & $0.00 E+01$ & $0.00 E+01$ & $0.00 E+01$ & $0.00 \mathrm{E}+01$ \\
\hline Am241 & & $2.15 E+04$ & & & & $3.39 E+02$ & & & $2.38 \mathrm{E}+02$ \\
\hline Am242 & $2.65 E-05$ & $1.94 \mathrm{E}-07$ & & & & $E-16$ & $4.11 \mathrm{E}-18$ & $3.01 \mathrm{E}-20$ & $2.21 \mathrm{E}-22$ \\
\hline Am242m & $2.66 \mathrm{E}-05$ & $1.95 E-07$ & & $1.05 \mathrm{E}-11$ & $7.69 \mathrm{E}-14$ & & & & \\
\hline & 2.44 & $2.22 E+02$ & $2.02 E+02$ & $1.84 E+02$ & $1.67 \mathrm{E}+02$ & $1.52 E+02$ & & & \\
\hline & & & & & $0.00 E+01$ & $0.00 E+01$ & $0.00 E+01$ & $0.00 E+01$ & $0.00 E+01$ \\
\hline A1217 & & & & & & $6 E+03$ & $6.86 \mathrm{E}+03$ & $41 E+03$ & $7.90 \mathrm{E}+03$ \\
\hline Ba137m & & & & & & & & $\mathrm{EE+01}$ & $0.00 E+01$ \\
\hline & & $1.22 \mathrm{E}+02$ & & & & $91 E+02$ & & & $6.19 E+02$ \\
\hline & 1.391 & $2.15 E-00$ & & & $8 E-00$ & $5.75 E-00$ & $6.77 \mathrm{E}-00$ & & \\
\hline & & $6.07 \mathrm{E}-00$ & & & & $6.07 \mathrm{E}-00$ & $6.07 E-00$ & & \\
\hline Bi21 & & & & & & $6.26 E+03$ & $6.86 \mathrm{E}+03$ & $E+03$ & $7.90 E+03$ \\
\hline Bi21 & & +02 & & & & & & +02 & $6.19 E+02$ \\
\hline Bk249 & & & & & & & & & $0.00 \mathrm{E}+0$ \\
\hline $8 k 250$ & & & & & & & & & \\
\hline 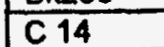 & & & & & & & & & \\
\hline & & & & & & & & +01 & \\
\hline Cd11 & & & & & $9.87 \mathrm{E}-22$ & $9.87 E-22$ & $9.87 \mathrm{E}-22$ & $9.87 \mathrm{E}-22$ & $9.87 E-2$ \\
\hline & & & & & & & & & $0.00 E+0$ \\
\hline Ce14 & & $E+01$ & & & & & & & \\
\hline & & & & & & & & & \\
\hline & & & & & & $0.00 \mathrm{E}+01$ & $0.00 E+01$ & & \\
\hline $\mathrm{C}(251$ & & & & & & $1.77 E-04$ & & & \\
\hline C1252 & & & & & & & & $E+01$ & $0.00 E+0$ \\
\hline $\mathrm{Cm} 242$ & & & & & & & & & \\
\hline & & & & & & & & & \\
\hline & & & & & & & & & \\
\hline C & & & & & & & & & $2.29 \mathrm{E}+0$ \\
\hline$\overline{\mathrm{Cr}}$ & & $7.15 E-01$ & & & & & & & \\
\hline & & $2.02 E-06$ & & & & & & & \\
\hline & & & & & $5.14 \mathrm{E}-01$ & $5.13 \mathrm{E}-\mathrm{C}$ & $5.12 \mathrm{E}$ & $5.10 E$ & \\
\hline & & & $0.00 E+01$ & $0.00 E+01$ & $0.00 E+01$ & $0.00 E+1$ & $0.00 E+01$ & & 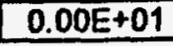 \\
\hline
\end{tabular}




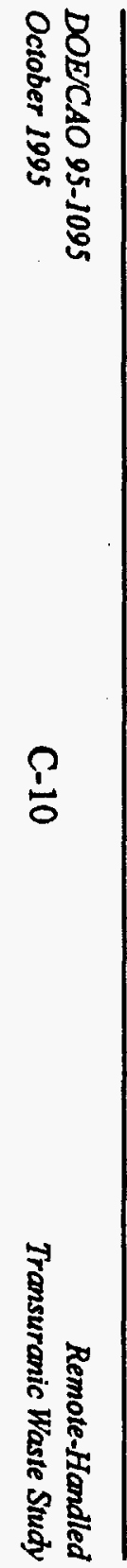

WIPP CH TRU WASTE STUDY-DATA FROM WIPP BIR REVISION 1

UNITS: Curies

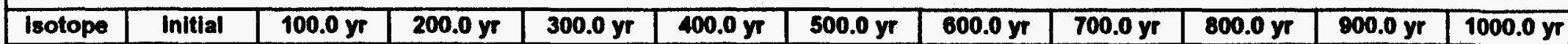
\begin{tabular}{|l|l|l|l|l|l|l|l|l|l|l|l|}
\hline Cs134 & $5.88 E+01$ & $1.48 E-13$ & $3.70 E-28$ & $0.00 E+01$ & $0.00 E+01$ & $0.00 E+01$ & $0.00 E+01$ & $0.00 E+01$ & $0.00 E+01$ & $0.00 E+01$ & $0.00 E+01$ \\
\hline
\end{tabular}

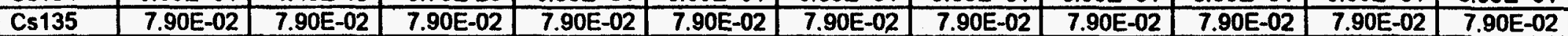

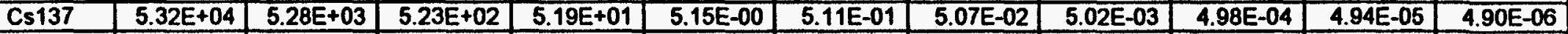

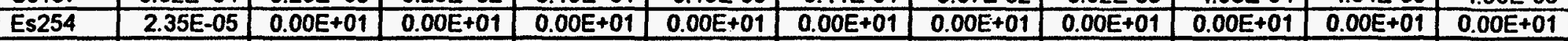
\begin{tabular}{|l|r|r|r|r|r|r|r|r|r|r|r|}
\hline Eu150 & $3.65 \mathrm{E}-04$ & $5.27 \mathrm{E}-05$ & $7.60 \mathrm{E}-06$ & $1.10 \mathrm{E}-06$ & $1.58 \mathrm{E}-07$ & $2.28 \mathrm{E}-08$ & $3.29 \mathrm{E}-09$ & $4.75 \mathrm{E}-10$ & $6.86 \mathrm{E}-11$ & $9.90 \mathrm{E}-12$ & $1.43 \mathrm{E}-12$ \\
\hline
\end{tabular}

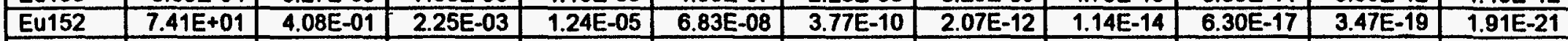

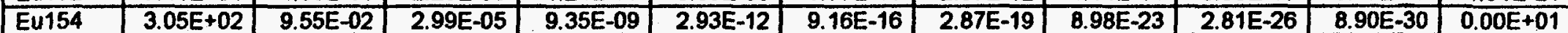

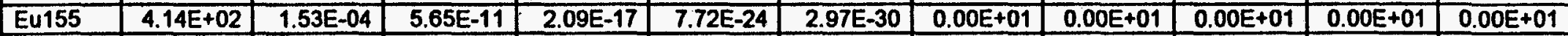
\begin{tabular}{|l|l|l|l|l|l|l|l|l|l|l|l|}
\hline $\mathrm{Fe} 55$ & $3.30 \mathrm{E}-04$ & $3.09 \mathrm{E}-15$ & $2.90 \mathrm{E}-26$ & $0.00 \mathrm{E}+01$ & $0.00 \mathrm{E}+01$ & $0.00 \mathrm{E}+01$ & $0.00 \mathrm{E}+01$ & $0.00 \mathrm{E}+01$ & $0.00 \mathrm{E}+01$ & $0.00 \mathrm{E}+01$ & $0.00 \mathrm{E}+01$ \\
\hline
\end{tabular} \begin{tabular}{|l|l|l|l|l|l|l|l|l|l|l|l|}
\hline Fe 59 & $1.96 E-01$ & $0.00 E+01$ & $0.00 E+01$ & $0.00 E+01$ & $0.00 E+01$ & $0.00 E+01$ & $0.00 E+01$ & $0.00 E+01$ & $0.00 E+01$ & $0.00 E+01$ & $0.00 E+01$ \\
\hline
\end{tabular} \begin{tabular}{|l|l|l|l|l|l|l|l|l|l|l|l|}
\hline F 221 & $2.03 E+01$ & $1.41 E+02$ & $2.61 E+02$ & $3.79 E+02$ & $4.97 E+02$ & $6.13 E+02$ & $7.28 E+02$ & $8.42 E+02$ & $9.55 E+02$ & $1.07 E+03$ & $1.18 E+03$ \\
\hline
\end{tabular}

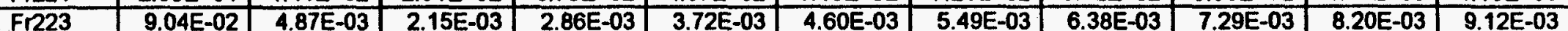

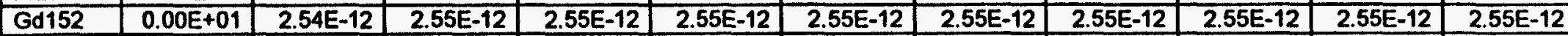

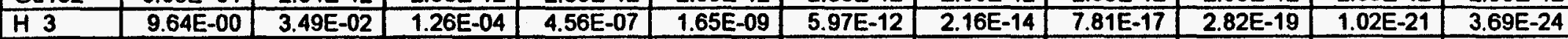

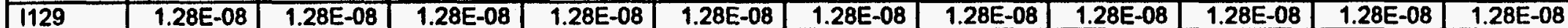
\begin{tabular}{|l|r|r|r|r|r|r|r|r|r|r|r|}
\hline $\mathrm{Kr} 85$ & $2.24 \mathrm{E}-00$ & $3.48 \mathrm{E}-03$ & $5.42 \mathrm{E}-06$ & $8.42 \mathrm{E}-09$ & $1.31 \mathrm{E}-11$ & $2.04 \mathrm{E}-14$ & $3.17 \mathrm{E}-17$ & $4.92 \mathrm{E}-20$ & $7.65 \mathrm{E}-23$ & $1.19 \mathrm{E}-25$ & $1.85 \mathrm{E}-28$ \\
\hline
\end{tabular} \begin{tabular}{llllllllll|l|l|l|l}
\hline $\mathrm{Mn} 54$ & $1.12 \mathrm{E}-01$ & $0.00 \mathrm{E}+01$ & $0.00 \mathrm{E}+01$ & $0.00 \mathrm{E}+01$ & $0.00 \mathrm{E}+01$ & $0.00 \mathrm{E}+01$ & $0.00 \mathrm{E}+01$ & $0.00 \mathrm{E}+01$ & $0.00 \mathrm{E}+01$ & $0.00 \mathrm{E}+01$ & $0.00 \mathrm{E}+01$ \\
\hline
\end{tabular}

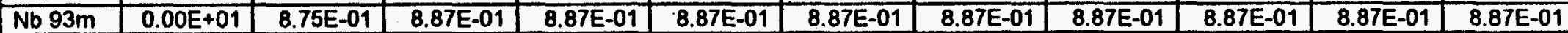

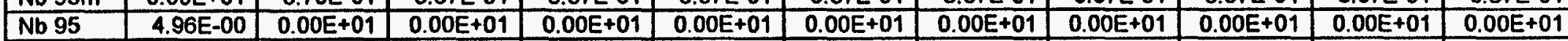

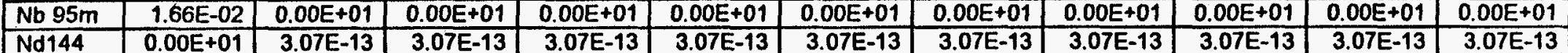

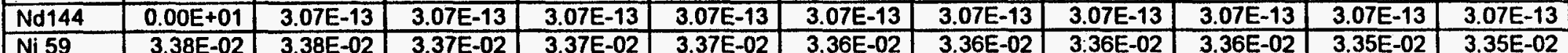

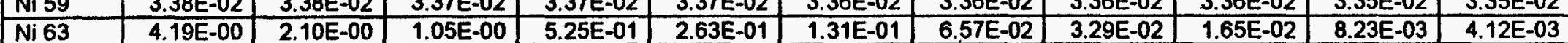

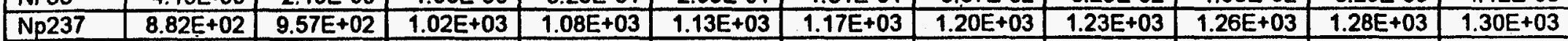

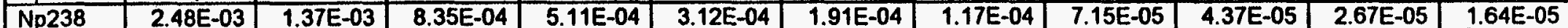
\begin{tabular}{|l|r|r|r|r|r|r|r|r|r|r|r|}
\hline Np239 & $2.94 E+02$ & $2.91 E+02$ & $2.89 E+02$ & $2.86 E+02$ & $2.83 E+02$ & $2.80 E+02$ & $2.78 E+02$ & $2.75 E+02$ & $2.73 E+02$ & $2.70 E+02$ & $2.68 E+02$ \\
\hline
\end{tabular}

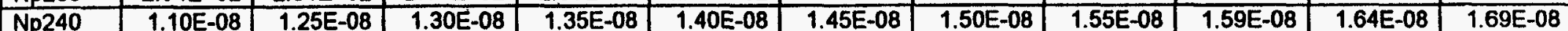

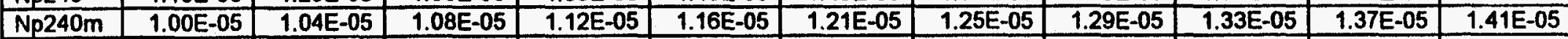

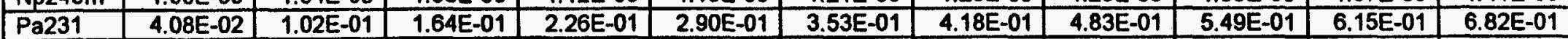

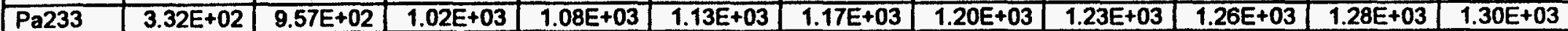

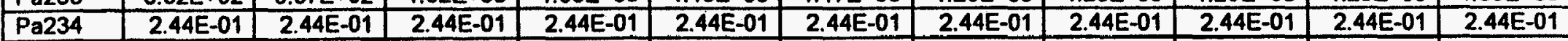

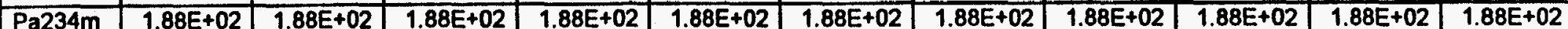
\begin{tabular}{|l|l|l|l|l|l|l|l|l|l|l|l|}
\hline $\mathrm{Pb209}$ & $2.03 E+01$ & $1.41 \mathrm{E}+02$ & $2.61 \mathrm{E}+02$ & $3.79 \mathrm{E}+02$ & $4.96 \mathrm{E}+02$ & $6.13 \mathrm{E}+02$ & $7.28 \mathrm{E}+02$ & $8.42 \mathrm{E}+02$ & $9.55 \mathrm{E}+02$ & $1.07 \mathrm{E}+03$ & $1.18 \mathrm{E}+03$ \\
\hline
\end{tabular} \begin{tabular}{|l|l|l|l|l|l|l|l|l|l|l|l|}
\hline $\mathrm{Pb210}$ & $1.01 \mathrm{E}+01$ & $5.45 \mathrm{E}+01$ & $5.45 \mathrm{E}+01$ & $5.28 \mathrm{E}+01$ & $5.14 \mathrm{E}+01$ & $5.05 \mathrm{E}+01$ & $4.99 \mathrm{E}+01$ & $4.97 \mathrm{E}+01$ & $4.98 \mathrm{E}+01$ & $5.03 \mathrm{E}+01$ & $5.12 \mathrm{E}+01$ \\
\hline
\end{tabular} \begin{tabular}{|l|l|l|l|l|l|l|l|l|l|l|l|}
\hline $\mathrm{Pb} 211$ & $6.57 \mathrm{E}-00$ & $3.54 \mathrm{E}-01$ & $1.56 \mathrm{E}-01$ & $2.07 \mathrm{E}-01$ & $2.70 \mathrm{E}-01$ & $3.33 \mathrm{E}-01$ & $3.98 \mathrm{E}-01$ & $4.63 \mathrm{E}-01$ & $5.28 \mathrm{E}-01$ & $5.94 \mathrm{E}-01$ & $6.61 \mathrm{E}-01$ \\
\hline
\end{tabular}

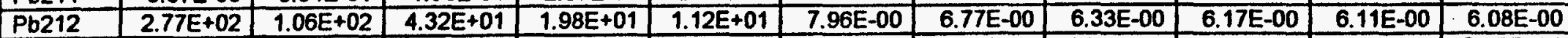
\begin{tabular}{|l|l|l|l|l|l|l|l|l|l|l|l|}
\hline $\mathrm{Pb} 214$ & $5.84 \mathrm{E}+01$ & $5.60 \mathrm{E}+01$ & $5.40 \mathrm{E}+01$ & $5.23 \mathrm{E}+01$ & $5.11 \mathrm{E}+01$ & $5.02 \mathrm{E}+01$ & $4.98 \mathrm{E}+01$ & $4.97 \mathrm{E}+01$ & $5.00 \mathrm{E}+01$ & $5.06 \mathrm{E}+01$ & $5.15 \mathrm{E}+01$ \\
\hline
\end{tabular} \begin{tabular}{|l|r|r|r|r|r|r|r|r|r|r|r|}
\hline Pd107 & $1.17 \mathrm{E}-02$ & $1.17 \mathrm{E}-02$ & $1.17 \mathrm{E}-02$ & $1.17 \mathrm{E}-02$ & $1.17 \mathrm{E}-02$ & $1.17 \mathrm{E}-02$ & $1.17 \mathrm{E}-02$ & $1.17 \mathrm{E}-02$ & $1.17 \mathrm{E}-02$ & $1.17 \mathrm{E}-02$ & $1.17 \mathrm{E}-02$ \\
\hline
\end{tabular} 


\begin{tabular}{|c|c|c|c|c|c|c|c|c|c|}
\hline \multicolumn{8}{|c|}{ WIPP CH TRU WASTE STUDY-DATA FROM WIPP BIR REVISION 1} & \multicolumn{2}{|c|}{ UNITS: Curies } \\
\hline Isotope & $2000.0 \mathrm{yr}$ & $3000.0 \mathrm{yr}$ & $4000.0 \mathrm{yr}$ & $5000.0 \mathrm{yr}$ & $6000.0 \mathrm{yr}$ & $7000.0 y r$ & $8000.0 \mathrm{yr}$ & $9000.0 \mathrm{yr}$ & 10000.0 \\
\hline Co 60 & $0.00 E+01$ & $0.00 \mathrm{E}+01$ & $0.00 E+01$ & $0.00 E+01$ & $0.00 E+01$ & $0.00 E+01$ & $0.00 \mathrm{E}+01$ & $0.00 E+01$ & $0.00 E+01$ \\
\hline Cs134 & $0.00 E+01$ & $0.00 E+01$ & $0.00 E+01$ & $0.00 E+01$ & $0.00 E+01$ & $0.00 E+01$ & $0.00 \mathrm{E}+01$ & $0.00 E+01$ & $0.00 E+01$ \\
\hline Cs135 & $7.90 \mathrm{E}-02$ & $7.89 \mathrm{E}-02$ & $7.89 E-02$ & $7.89 \mathrm{E}-02$ & $7.89 E-02$ & $7.88 \mathrm{E}-02$ & $7.88 E-02$ & $7.88 \mathrm{E}-02$ & $7.88 E-02$ \\
\hline Cs137 & $4.52 \mathrm{E}-16$ & $4.16 \mathrm{E}-26$ & $0.00 \mathrm{E}+01$ & $0.00 E+01$ & $0.00 E+01$ & $0.00 E+01$ & $0.00 E+01$ & $0.00 E+01$ & $0.00 E+01$ \\
\hline Es254 & $0.00 E+01$ & $0.00 E+01$ & $0.00 E+01$ & $0.00 E+01$ & $0.00 E+01$ & $0.00 E+01$ & $0.00 \mathrm{E}+01$ & $0.00 E+01$ & $0.00 E+01$ \\
\hline Eu150 & 5.59E-21 & $2.19 E-29$ & $0.00 E+01$ & $0.00 E+01$ & $0.00 E+01$ & $0.00 E+01$ & $0.00 E+01$ & $0.00 E+01$ & $0.00 \mathrm{E}+01$ \\
\hline Eu152 & $0.00 E+01$ & $0.00 E+01$ & $0.00 E+01$ & $0.00 E+01$ & $0.00 E+01$ & $0.00 E+01$ & $0.00 E+01$ & $0.00 E+01$ & $0.00 E+01$ \\
\hline Eu154 & $0.00 E+01$ & $0.00 E+01$ & $0.00 E+01$ & $0.00 E+01$ & $0.00 E+01$ & $0.00 \mathrm{E}+01$ & $0.00 \mathrm{E}+01$ & $0.00 E+01$ & $0.00 E+01$ \\
\hline Eu155 & $0.00 E+01$ & $0.00 E+01$ & $0.00 E+01$ & $0.00 E+01$ & $0.00 E+01$ & $0.00 \mathrm{E}+01$ & $0.00 E+01$ & $0.00 E+01$ & $0.00 E+01$ \\
\hline $\mathrm{Fe} 55$ & $0.00 E+01$ & $0.00 E+01$ & $0.00 E+01$ & $0.00 E+01$ & $0.00 E+01$ & $0.00 E+01$ & $0.00 E+01$ & $0.00 E+01$ & $E+01$ \\
\hline Fe 59 & $0.00 E+01$ & $0.00 E+01$ & +01 & $0.00 E+01$ & $0 E+01$ & $0.00 E+01$ & $0.00 \mathrm{E}+01$ & $0.00 \mathrm{E}+01$ & $0.00 \mathrm{E}+01$ \\
\hline Fr221 & $2.23 E+03$ & $3.20 E+03$ & $4.07 E+03$ & $4.87 E+03$ & $5.60 E+03$ & $6.26 E+03$ & $6.86 \mathrm{E}+03$ & $7.41 E+03$ & $7.90 \mathrm{E}+03$ \\
\hline $\mathrm{Fr223}$ & $1.92 E-02$ & 2.97E-02 & $4.11 E-02$ & $5.32 E-02$ & $6.60 \mathrm{E}-02$ & $7.94 E-02$ & 9.35E-02 & 1.08E-01 & $3 E-01$ \\
\hline Gd152 & $2.55 \mathrm{E}-12$ & $2.55 \mathrm{E}-12$ & -12 & $2.55 \mathrm{E}-12$ & $2.55 E-12$ & EE-12 & $2.55 E-12$ & $2.55 E-12$ & $2.55 E-12$ \\
\hline $\mathrm{H3}$ & 0.00 & $E+01$ & +01 & +01 & $0.00 E+01$ & $0.00 E+01$ & $0.00 E+01$ & $0.00 E+01$ & $0.00 E+01$ \\
\hline 1129 & $1.28 E-08$ & $1.28 \mathrm{E}-08$ & $1.28 \mathrm{E}-08$ & $1.28 \mathrm{E}-08$ & $1.28 \mathrm{E}-08$ & $1.28 \mathrm{E}-08$ & $1.28 \mathrm{E}-08$ & $1.28 \mathrm{E}-08$ & $1.28 \mathrm{E}-08$ \\
\hline $\mathrm{Kr} 85$ & $0.00 \mathrm{E}+01$ & $0.00 E+01$ & $0.00 \mathrm{E}+01$ & $0.00 \mathrm{E}+01$ & $0.00 E+01$ & $E+01$ & $E+01$ & $\mathrm{E}+01$ & $E+01$ \\
\hline Mn 54 & +01 & +01 & +01 & +01 & +01 & $0.00 E+01$ & $E+01$ & $0.00 E+01$ & $0.00 \mathrm{E}+01$ \\
\hline $\mathrm{Nb} 93 \mathrm{~m}$ & $5-01$ & $8.86 \mathrm{E}-01$ & $8.85 E-01$ & $8.85 E-01$ & 8.85E-01 & $8.84 E-01$ & E-01 & $8.83 E-01$ & $8.83 \mathrm{E}-01$ \\
\hline $\mathrm{Nb} 95$ & $0.00 E+01$ & $0.00 E+01$ & $0.00 E+01$ & $0.00 E+01$ & $0.00 E+01$ & $E+01$ & $0.00 E+01$ & $0.00 E+01$ & $E+01$ \\
\hline $\mathrm{Nb} 95 \mathrm{~m}$ & $0.00 \mathrm{E}+01$ & $0.00 \mathrm{E}+01$ & +01 & +01 & $=01$ & $0.00 E+01$ & $0.00 \mathrm{E}+01$ & $0.00 E+01$ & $0.00 E+01$ \\
\hline Nd144 & -13 & $3.07 E-13$ & $3.07 \mathrm{E}-13$ & $3.07 \mathrm{E}-13$ & $3.07 \mathrm{E}-13$ & $3.07 \mathrm{E}-13$ & $3.07 E-13$ & $3.07 \mathrm{E}-13$ & $3.07 \mathrm{E}-13$ \\
\hline Ni 59 & -02 & $3.29 \mathrm{E}-02$ & $3.26 \mathrm{E}-02$ & -02 & $3.20 \mathrm{E}-02$ & $3.17 \mathrm{E}-02$ & $3.14 E-02$ & E-02 & $8 E-02$ \\
\hline Ni 63 & 4.05E-06 & $3.98 \mathrm{E}-09$ & 3.91E-12 & $3.84 E-15$ & $3.78 E-18$ & $3.71 \mathrm{E}-21$ & $3.65 E-24$ & $3.59 \mathrm{E}-27$ & $3.42 E-30$ \\
\hline Np237. & +03 & $1.40 E+03$ & 03 & $1.40 E+03$ & $1.40 E+03$ & $1.40 E+03$ & $1.40 E+03$ & $1.40 E+03$ & $1.40 E+03$ \\
\hline Np238 & $1.20 \mathrm{E}-07$ & $8.79 \mathrm{E}-10$ & $6.44 E-12$ & $4.72 E-14$ & $3.46 E-16$ & $2.54 E-18$ & $1.86 \mathrm{E}-20$ & $1.36 \mathrm{E}-22$ & $9.98 \mathrm{E}-25$ \\
\hline Np239 & $2.44 E+02$ & $2.22 E+02$ & $2.02 E+02$ & $1.84 E+02$ & $1.67 E+02$ & $1.52 E+02$ & $1.39 \mathrm{E}+02$ & $1.26 \mathrm{E}+02$ & $1.15 E+02$ \\
\hline Np240 & $2.19 E-08$ & $2.68 E-08$ & $3.17 E-08$ & $3.66 E-08$ & $4.15 E-08$ & $4.64 E-08$ & $5.13 E-08$ & $5.62 E-08$ & $6.10 \mathrm{E}-08$ \\
\hline $\mathrm{Np240m}$ & $1.82 \mathrm{E}-05$ & $2.23 E-05$ & $2.64 E-05$ & 3.05E-05 & $3.46 \mathrm{E}-05$ & 3.87E-05 & $4.27 \mathrm{E}-05$ & $4.68 \mathrm{E}-05$ & 5.08E-05 \\
\hline P2231 & 1.39E-00 & $2.15 E-00$ & $2.98 \mathrm{E}-00$ & $3.85 E-00$ & $4.78 \mathrm{E}-00$ & $5.75 E-00$ & $6.77 \mathrm{E}-00$ & $7.83 E-00$ & $8.93 \mathrm{E}-00$ \\
\hline Pa233 & $1.38 E+03$ & $1.40 E+03$ & $1.40 \mathrm{E}+03$ & $1.40 E+03$ & $1.40 E+03$ & $1.40 \mathrm{E}+03$ & $1.40 \mathrm{E}+03$ & $1.40 \mathrm{E}+03$ & $1.40 E+03$ \\
\hline$P_{2234}$ & $2.44 E-01$ & 2.44E-01 & $2.44 E-01$ & $2.44 E-01$ & $2.44 \mathrm{E}-01$ & $2.44 \mathrm{E}-01$ & 2.44E-01 & 2.44E-01 & $2.44 \mathrm{E}-01$ \\
\hline Pa234m & $1.88 E+02$ & $1.88 E+02$ & $1.88 E+02$ & $1.88 E+02$ & $1.88 E+02$ & $1.88 E+02$ & $1.88 E+02$ & $1.88 E+02$ & $1.88 E+02$ \\
\hline Pb209 & $2.23 E+03$ & $3.20 \mathrm{E}+03$ & $4.07 E+03$ & $4.87 E+03$ & $5.60 E+03$ & $6.26 \mathrm{E}+03$ & $6.86 E+03$ & $7.41 E+03$ & $7.90 \mathrm{E}+03$ \\
\hline Pb210 & $7.63 \mathrm{E}+01$ & $1.22 E+02$ & $1.80 E+02$ & $2.46 E+02$ & $3.17 E+02$ & $3.91 E+02$ & $4.67 E+02$ & $5.43 E+02$ & $6.19 E+02$ \\
\hline $\mathrm{Pb211}$ & $1.39 E-00$ & $2.15 E-00$ & $2.98 E-00$ & $3.85 E-00$ & $4.78 E-00$ & $5.75 E-00$ & $6.77 E-00$ & $7.83 \mathrm{E}-00$ & $8.93 E-00$ \\
\hline $\mathrm{Pb212}$ & 6.07E-00 & $6.07 E-00$ & $6.07 E-00$ & $6.07 E-00$ & 6.07E-00 & $6.07 E-00$ & $6.07 \mathrm{E}-00$ & $6.07 E-00$ & $6.07 \mathrm{E}-00$ \\
\hline $\mathrm{Pb214}$ & $7.64 \mathrm{E}+01$ & $1.22 E+02$ & $1.80 E+02$ & $2.46 \mathrm{E}+02$ & $3.17 \mathrm{E}+02$ & $3.91 E+02$ & $4.67 E+02$ & $5.43 E+02$ & $6.19 E+02$ \\
\hline
\end{tabular}




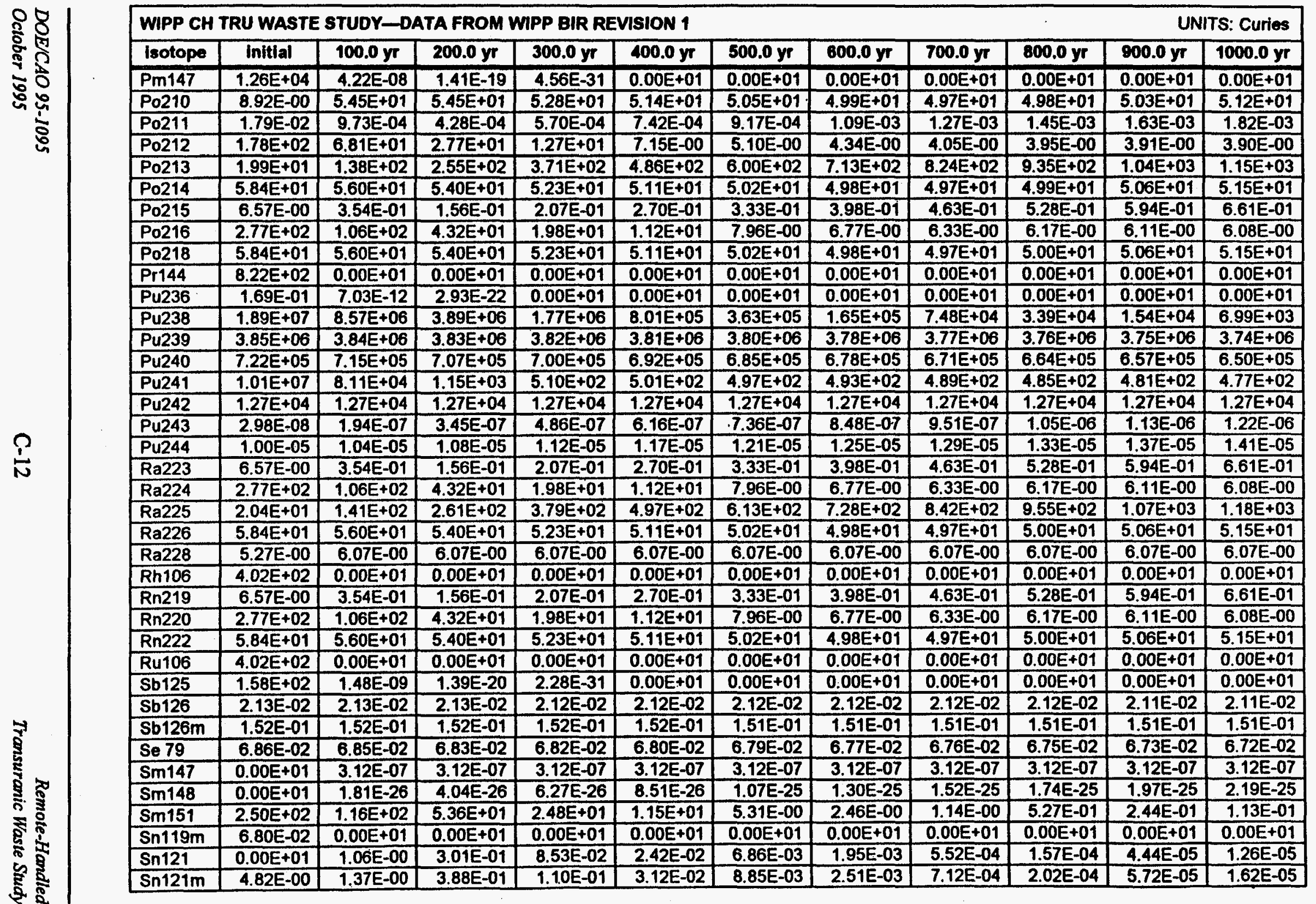




\begin{tabular}{|c|c|c|c|c|c|c|c|c|c|}
\hline \multicolumn{8}{|c|}{ WPP CH TRU WASTE STUDY -DATA FROM WIPP BIR REVISION 1} & \multicolumn{2}{|c|}{ UNITS: Curies } \\
\hline 18otope & $2000.0 \mathrm{yr}$ & $3000.0 \mathrm{yr}$ & $4000.0 \mathrm{yr}$ & $5000.0 \mathrm{yr}$ & $6000.0 \mathrm{yr}$ & $7000.0 \mathrm{yr}$ & $8000.0 \mathrm{yr}$ & $9000.0 \mathrm{yr}$ & 10000.0 \\
\hline Pd107 & 1.17E-02 & 1.17E-02 & 1.17E-02 & 1.17E-02 & 1.17E-02 & 1.17E-02 & 1.17E-02 & 1.17E-02 & $1.17 E-02$ \\
\hline Pm147 & $0.00 E+01$ & $0.00 E+01$ & $0.00 E+01$ & $0.00 E+01$ & $0.00 E+01$ & $0.00 E+01$ & $0.00 E+01$ & $0.00 E+01$ & $0.00 E+01$ \\
\hline P0210 & $7.63 \mathrm{E}+01$ & $1.22 E+02$ & $1.80 E+02$ & $2.46 E+02$ & $3.17 E+02$ & $3.91 E+02$ & $4.67 E+02$ & $5.43 E+02$ & $6.19 E+02$ \\
\hline P0211 & $3.82 \mathrm{E}-03$ & $5.92 \mathrm{E}-03$ & $8.19 \mathrm{E}-03$ & $1.06 \mathrm{E}-02$ & $1.31 \mathrm{E}-02$ & $1.58 \mathrm{E}-02$ & $1.86 \mathrm{E}-02$ & $2.15 \mathrm{E}-02$ & $2.46 \mathrm{E}-02$ \\
\hline P0212 & $3.89 \mathrm{E}-00$ & $3.89 \mathrm{E}-00$ & $3.89 \mathrm{E}-00$ & $3.89 \mathrm{E}-00$ & $3.89 E-00$ & $3.89 \mathrm{E}-00$ & $3.89 \mathrm{E}-00$ & $3.89 E-00$ & $3.89 \mathrm{E}-00$ \\
\hline Po213 & $2.19 E+03$ & $3.13 E+03$ & $3.99 E+03$ & $4.77 E+03$ & $5.48 E+03$ & $6.13 E+03$ & $6.72 E+03$ & $7.25 E+03$ & $7.74 E+03$ \\
\hline Po214 & $7.63 E+01$ & $1.22 E+02$ & $1.80 E+02$ & $2.46 E+02$ & $3.17 \mathrm{E}+02$ & $3.91 E+02$ & $4.67 E+02$ & $5.43 \mathrm{E}+02$ & $6.19 E+02$ \\
\hline P0215 & $1.39 E-00$ & $2.15 E-00$ & $2.98 \mathrm{E}-00$ & $3.85 E-00$ & $4.78 \mathrm{E}-00$ & $5.75 E-00$ & $.6 .77 \mathrm{E}-00$ & $7.83 E-00$ & $8.93 \mathrm{E}-00$ \\
\hline P0216 & $6.07 \mathrm{E}-00$ & $6.07 \mathrm{E}-00$ & $6.07 E-00$ & $6.07 \mathrm{E}-00$ & 6.07E-00 & $6.07 E-00$ & $6.07 \mathrm{E}-00$ & 6.07E-00 & $6.07 E-00$ \\
\hline $\mathrm{P} 0218$ & $7.64 E+01$ & $1.22 E+02$ & $1.80 E+02$ & $2.46 E+02$ & $3.17 E+02$ & $3.91 E+02$ & $4.67 E+02$ & $5.43 E+02$ & $6.19 E+02$ \\
\hline Pr144 & $0.00 E+01$ & $0.00 E+01$ & $0.00 E+01$ & $0.00 E+01$ & $0.00 E+01$ & $0.00 E+01$ & $0.00 E+01$ & $0.00 E+01$ & $0.00 E+01$ \\
\hline Pu236 & $0.00 E+01$ & $E+01$ & $=+01$ & +01 & +01 & $5+01$ & $E+01$ & $E+01$ & $E+01$ \\
\hline Pu238 & & $9.54 \mathrm{E}-04$ & $3.54 E-07$ & $1.39 \mathrm{E}-10$ & $1.15 E-13$ & $5.09 \mathrm{E}-16$ & $3.61 \mathrm{E}-18$ & $2.64 \mathrm{E}-20$ & $1.93 \mathrm{E}-22$ \\
\hline Pu239 & $3.63 E+06$ & $3.53 E+06$ & $3.43 E+06$ & $3.33 E+06$ & $3.24 E+06$ & $3.15 E+06$ & $3.06 \mathrm{E}+06$ & $2.97 \mathrm{E}+06$ & $2.89 E+06$ \\
\hline Pu240 & $5.85 E+05$ & $5.26 E+05$ & & $E+05$ & $3.83 E+05$ & $3.45 E+05$ & +05 & $E+05$ & $E+05$ \\
\hline Pu241 & +02 & $4.05 E+02$ & +02 & $3.44 E+02$ & $E+02$ & $E+02$ & $E+02$ & $E+02$ & $E+02$ \\
\hline Pu242 & $1.27 E+04$ & $1.26 E+04$ & $1.26 E+04$ & $1.26 E+04$ & $1.26 E+04$ & $1.25 E+04$ & $1.25 \mathrm{E}+04$ & $1.25 E+04$ & $1.25 E+04$ \\
\hline Pu243. & $1.76 \mathrm{E}-06$ & $2.02 \mathrm{E}-06$ & 2.13E-06 & $2.19 \mathrm{E}-06$ & 2.21E-06 & 2.23E-06 & 2.23E-06 & $2.23 E-06$ & 2.23E-06 \\
\hline Pu244 & & $4 E-05$ & & -05 & & -05 & $=-05$ & -05 & $E-05$ \\
\hline $\operatorname{Ra223}$ & $=-00$ & $2.15 \mathrm{E}-00$ & -00 & $=00$ & $=-00$ & $5.75 E-00$ & $E-00$ & $7.83 \mathrm{E}-00$ & $E-00$ \\
\hline$\overline{\operatorname{Ra224}}$ & $6.07 \mathrm{E}-00$ & $6.07 \mathrm{E}-00$ & $6.07 \mathrm{E}-00$ & $6.07 \mathrm{E}-00$ & 6.07E-00 & $6.07 E-00$ & $6.07 \mathrm{E}-00$ & $6.07 \mathrm{E}-00$ & 6.07E-00 \\
\hline Ra225 & $2.23 E+03$ & $3.20 E+03$ & $4.07 E+03$ & $4.87 E+03$ & & $6.26 E+03$ & $6.86 E+03$ & $E+03$ & $E+03$ \\
\hline Ra226 & & +02 & +02 & +02 & +02 & $=+02$ & $4.67 E+02$ & $E+02$ & $6.19 E+02$ \\
\hline $\operatorname{Ra228}$ & $6.07 \mathrm{E}-00$ & 6.07E-00 & $6.07 E-00$ & $E-00$ & $E-00$ & $6.07 E-00$ & $6.07 \mathrm{E}-00$ & $6.07 \mathrm{E}-00$ & $6.07 E-00$ \\
\hline Rh106 & $0.00 E+01$ & $0.00 \mathrm{E}+01$ & $0.00 \mathrm{E}+01$ & $0.00 E+01$ & $0.00 E+01$ & $0.00 E+01$ & $0.00 \mathrm{E}+01$ & $0.00 \mathrm{E}+01$ & $0.00 \mathrm{E}+01$ \\
\hline $\operatorname{Rn} 219$ & $1.39 E-00$ & $2.15 E-00$ & & & & & & -00 & $8.93 E-00$ \\
\hline Rn220 & & $E-00$ & $=00$ & 00 & $6.07 E-00$ & $E-00$ & 6.07E-00 & $7 E-00$ & $6.07 E-00$ \\
\hline Rn222 & $7.64 E+01$ & $1.22 E+02$ & $1.80 E+02$ & $2.46 E+02$ & $3.17 E+02$ & $3.91 E+02$ & $4.67 \mathrm{E}+02$ & $5.43 E+02$ & $6.19 E+02$ \\
\hline Ru106 & $0.00 E+01$ & $0.00 E+01$ & $0.00 E+01$ & $0.00 E+01$ & $0.00 E+01$ & $0.00 E+01$ & $0.00 E+01$ & $0.00 E+01$ & $0.00 E+01$ \\
\hline Sb125 & $0.00 E+01$ & $0.00 E+01$ & $0.00 E+01$ & $0.00 E+01$ & & $0.00 E+01$ & $0 E+01$ & $0.00 E+01$ & $0.00 E+01$ \\
\hline Sb126 & & $2.08 \mathrm{E}-02$ & $2.07 E-02$ & & $2.04 \mathrm{E}-02$ & 2.0 & $E-02$ & $2.00 \mathrm{E}-02$ & $1.99 \mathrm{E}-02$ \\
\hline & & $1.49 \mathrm{E}-01$ & $1.48 E-01$ & 1.47E-01 & $1.46 E-01$ & $1.45 \mathrm{E}-01$ & $1.44 E-01$ & 1.43E-01 & $1.42 E-01$ \\
\hline Se 79 & $6.58 E-02$ & $6.44 E-02$ & $6.31 \mathrm{E}-02$ & 6.18E-02 & $6.05 E-02$ & $5.92 E-02$ & $5.80 E-02$ & $5.68 \mathrm{E}-02$ & $5.56 \mathrm{E}-02$ \\
\hline Sm147 & $3.12 \mathrm{E}-07$ & $3.12 E-07$ & $3.12 E-07$ & $3.12 E-07$ & $3.12 E-07$ & $3.12 E-07$ & $3.12 E-07$ & $3.12 \mathrm{E}-07$ & \\
\hline Sm148 & $4.43 E-25$ & $6.66 \mathrm{E}-25$ & $8.89 \mathrm{E}-25$ & $1.11 \mathrm{E}-24$ & $1.34 \mathrm{E}-24$ & $1.56 \mathrm{E}-24$ & $1.78 E-24$ & 2.01E-24 & $2.23 \mathrm{E}-24$ \\
\hline Sm151 & $5.10 \mathrm{E}-05$ & $2.30 E-08$ & & $4.69 \mathrm{E}-15$ & $2.12 \mathrm{E}-18$ & $9.57 \mathrm{E}-22$ & $4.32 E-25$ & $1.95 \mathrm{E}-28$ & $0.00 E+01$ \\
\hline Sn119m & $0.00 E+01$ & $0.00 E+01$ & $0.00 E+01$ & $0.00 E+01$ & $0.00 E+01$ & $0.00 \mathrm{E}+01$ & $0.00 E+01$ & $0.00 E+01$ & $0.00 E+01$ \\
\hline Sn121 & $4.24 \mathrm{E}-11$ & $1.43 \mathrm{E}-16$ & $4.81 E-22$ & $1.62 \mathrm{E}-27$ & $0.00 E+01$ & $0.00 E+01$ & $0.00 E+01$ & $0.00 \mathrm{E}+01$ & $0.00 E+01$ \\
\hline
\end{tabular}




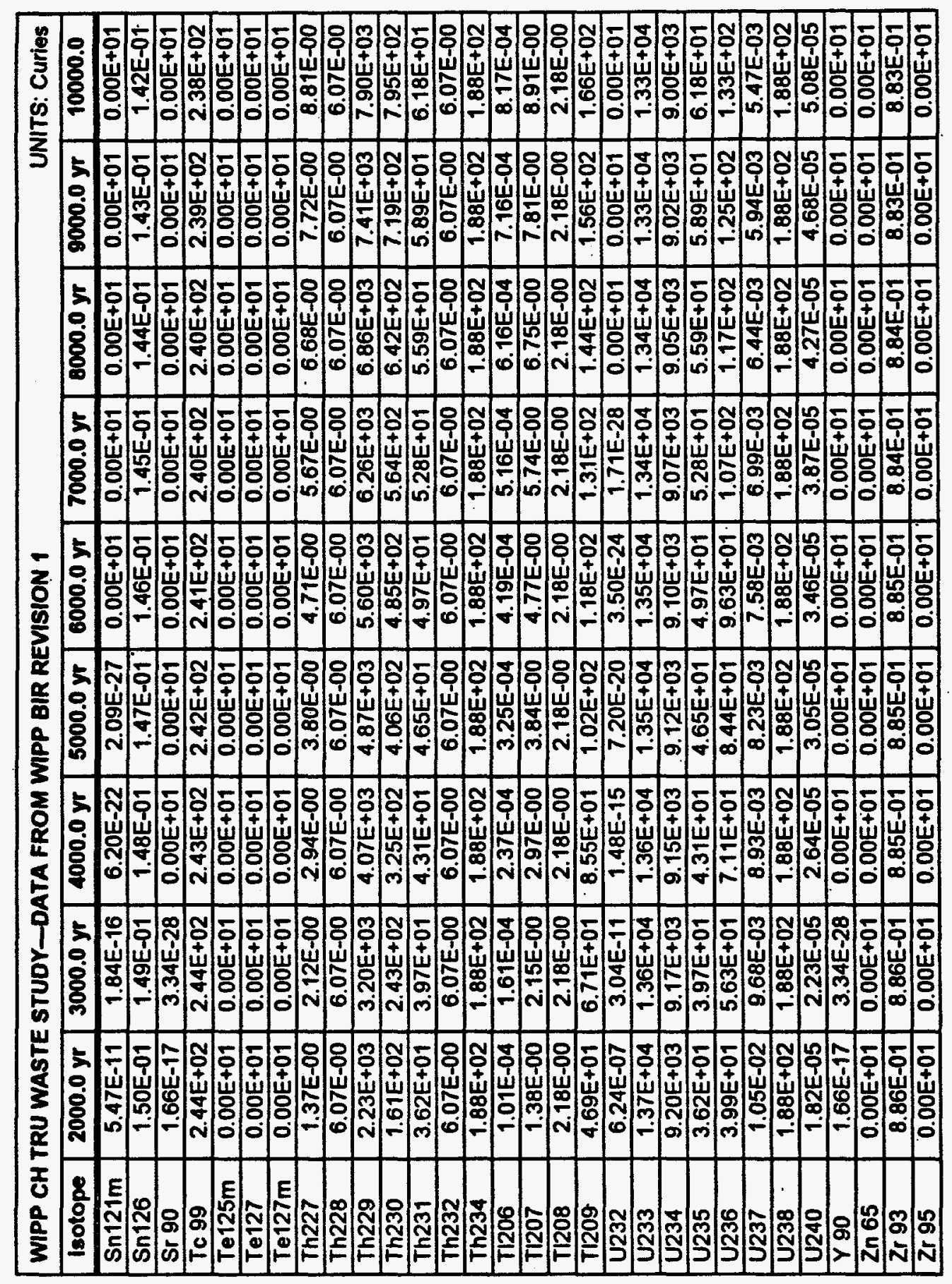




\begin{tabular}{|c|c|c|c|c|c|c|c|c|c|c|c|c|}
\hline \multirow{7}{*}{ 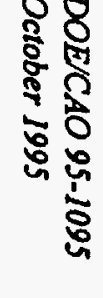 } & \multicolumn{10}{|c|}{ WIPP RH TRU WASTE STUDY-DATA FROM WIPP BIR REVISION 1} & \multicolumn{2}{|c|}{ UNITS: Curies } \\
\hline & isotope & Initial & $100.0 \mathrm{yz}$ & $200.0 \mathrm{yr}$ & $300.0 \mathrm{yr}$ & $400.0 \mathrm{yr}$ & $500.0 \mathrm{yr}$ & $600.0 \mathrm{yr}$ & $700.0 \mathrm{yr}$ & $800.0 \mathrm{yr}$ & $900.0 \mathrm{yr}$ & $1000.0 \mathrm{yr}$ \\
\hline & Ac225 & $3.28 \mathrm{E}-00$ & $7.84 E+01$ & $1.53 E+02$ & $2.26 E+02$ & $2.99 E+02$ & $3.72 E+02$ & $4.43 E+02$ & $5.14 E+02$ & $5.84 E+02$ & $6.54 E+02$ & $7.23 E+02$ \\
\hline & Ac227 & $1.52 \mathrm{E}-01$ & $1.80 \mathrm{E}-00$ & $1.97 \mathrm{E}-00$ & $2.09 E-00$ & 2.21E-00 & $2.32 \mathrm{E}-00$ & $2.44 E-00$ & $2.55 E-00$ & 2.67E-00 & $2.78 \mathrm{E}-00$ & $2.89 \mathrm{E}-00$ \\
\hline & Ac228 & 4.08E-02 & 7.09E-02 & $7.09 E-02$ & 7.09E-02 & 7.09E-02 & $7.09 \mathrm{E}-02$ & $7.09 \mathrm{E}-02$ & $7.09 \mathrm{E}-02$ & $7.09 \mathrm{E}-02$ & $7.09 \mathrm{E}-02$ & $7.09 \mathrm{E}-02$ \\
\hline & Ag110 & 1.07E-04 & $0.00 E+01$ & $0.00 E+01$ & $0.00 E+01$ & $0.00 E+01$ & $0.00 E+01$ & $0.00 E+01$ & $0.00 E+01$ & $0.00 E+01$ & $0.00 E+01$ & $0.00 \mathrm{E}+01$ \\
\hline & Ag110m & $8.06 \mathrm{E}-03$ & $0.00 E+01$ & $0.00 E+01$ & $0.00 E+01$ & $0.00 \mathrm{E}+01$ & $0.00 E+01$ & $0.00 E+01$ & $0.00 \mathrm{E}+01$ & $0.00 E+01$ & $0.00 E+01$ & $0.00 E+01$ \\
\hline \multirow{25}{*}{$\stackrel{?}{a}$} & Am241 & $5.30 E+03$ & $4.78 E+03$ & $4.07 E+03$ & $3.47 E+03$ & $2.96 E+03$ & $2.52 E+03$ & $2.14 E+03$ & $1.83 E+03$ & $1.56 E+03$ & $1.33 E+03$ & $1.13 E+03$ \\
\hline & Am243 & $1.22 \mathrm{E}-01$ & $2.90 E-01$ & $3.02 E-01$ & $3.01 E-01$ & $2.98 \mathrm{E}-01$ & 2.95E-01 & 2.92E-01 & 2.90E-01 & $2.87 \mathrm{E}-01$ & $2.84 E-01$ & 2.81E-01 \\
\hline & Am245 & $2.52 E-13$ & $0.00 E+01$ & $0.00 E+01$ & $0.00 E+01$ & $0.00 E+01$ & $0.00 E+01$ & $0.00 E+01$ & $0.00 E+01$ & $0.00 E+01$ & $0.00 E+01$ & $0.00 E+01$ \\
\hline & At217 & $3.28 \mathrm{E}-00$ & $7.84 E+01$ & $1.53 E+02$ & $2.26 E+02$ & $2.99 E+02$ & $3.72 E+02$ & $4.43 E+02$ & $5.14 \mathrm{E}+02$ & $5.84 E+02$ & $6.54 E+02$ & $7.23 E+02$ \\
\hline & Ba137m & $3.10 E+06$ & $3.07 E+05$ & $3.05 E+04$ & $3.02 E+03$ & $3.00 \mathrm{E}+02$ & $2.97 E+01$ & $2.95 \mathrm{E}-00$ & $2.93 \mathrm{E}-01$ & $2.90 \mathrm{E}-02$ & $2.88 \mathrm{E}-03$ & $2.85 E-04$ \\
\hline & $8 i 210$ & $4.09 \mathrm{E}-10$ & $3.08 \mathrm{E}-05$ & $2.69 \mathrm{E}-04$ & $8.65 E-04$ & $1.88 \mathrm{E}-03$ & $3.34 \mathrm{E}-03$ & 5.23E-03 & $7.55 E-03$ & $1.03 E-02$ & $1.34 \mathrm{E}-02$ & $1.69 \mathrm{E}-02$ \\
\hline & $B i 211$ & $1.46 \mathrm{E}-01$ & $1.80 E-00$ & $1.97 \mathrm{E}-00$ & 2.09E-00 & 2.21E-00 & $2.32 \mathrm{E}-00$ & 2.44E-00 & $2.55 E-00$ & 2.67E-00 & 2.78E-00 & $2.89 E-00$ \\
\hline & Bi212 & $9.03 E+01$ & $4.43 E+01$ & $1.64 E+01$ & $6.13 \mathrm{E}-00$ & $2.32 \mathrm{E}-00$ & $9.03 \mathrm{E}-01$ & $3.79 \mathrm{E}-01$ & $1.85 \mathrm{E}-01$ & $1.13 \mathrm{E}-01$ & $8.66 \mathrm{E}-02$ & $7.67 \mathrm{E}-02$ \\
\hline & Bi213 & $3.28 \mathrm{E}-00$ & $7.84 E+01$ & $1.53 E+02$ & $2.26 E+02$ & $2.99 E+02$ & $3.72 E+02$ & $4.43 E+02$ & $5.14 E+02$ & $5.84 E+02$ & $6.54 E+02$ & $7.23 E+02$ \\
\hline & $B i 214$ & $7.23 \mathrm{E}-09$ & $6.31 E-05$ & $3.98 \mathrm{E}-04$ & $1.12 E-03$ & $2.28 E-03$ & $3.88 \mathrm{E}-03$ & 5.91E-03 & $8.36 \mathrm{E}-03$ & $1.12 \mathrm{E}-02$ & $1.45 \mathrm{E}-02$ & $1.81 \mathrm{E}-02$ \\
\hline & Bk249 & $1.74 \mathrm{E}-08$ & $0.00 E+01$ & $0.00 \mathrm{E}+01$ & $0.00 E+01$ & $0.00 E+01$ & $0.00 E+01$ & $0.00 E+01$ & $0.00 E+01$ & $0.00 E+01$ & $0.00 E+01$ & $0.00 E+01$ \\
\hline & C 14 & $1.51 E+03$ & $1.49 E+03$ & $1.47 E+03$ & $1.46 E+03$ & $1.44 E+03$ & $1.42 E+03$ & $1.40 E+03$ & $1.39 E+03$ & $1.37 E+03$ & $1.35 E+03$ & $1.34 E+03$ \\
\hline & Cd113 & $0.00 E+01$ & $4.97 \mathrm{E}-22$ & $5.01 \mathrm{E}-22$ & $5.01 \mathrm{E}-22$ & $5.01 E-22$ & $5.01 \mathrm{E}-22$ & $5.01 \mathrm{E}-22$ & $5.01 E-22$ & $5.01 \mathrm{E}-22$ & $5.01 \mathrm{E}-22$ & $5.01 \mathrm{E}-22$ \\
\hline & Cd113m & $2.36 E-04$ & $1.73 E-06$ & $1.27 E-08$ & $9.29 \mathrm{E}-11$ & $6.81 E-13$ & $4.99 \mathrm{E}-15$ & $3.66 \mathrm{E}-17$ & $2.68 \mathrm{E}-19$ & $1.96 \mathrm{E}-21$ & $1.44 E-23$ & $1.06 \mathrm{E}-25$ \\
\hline & Ce144 & $5.58 E+03$ & $0.00 E+01$ & $0.00 E+01$ & $0.00 E+01$ & $0.00 E+01$ & $0.00 E+01$ & $0.00 \mathrm{E}+01$ & $0.00 E+01$ & $0.00 \mathrm{E}+01$ & $0.00 \mathrm{E}+01$ & $0.00 E+01$ \\
\hline & Cा249 & $8.11 \mathrm{E}-01$ & $6.65 \mathrm{E}-01$ & $5.46 \mathrm{E}-01$ & $4.48 \mathrm{E}-01$ & $3.68 \mathrm{E}-01$ & $3.02 \mathrm{E}-01$ & $2.48 \mathrm{E}-01$ & $2.03 \mathrm{E}-01$ & $1.67 \mathrm{E}-01$ & $1.37 \mathrm{E}-01$ & $1.12 \mathrm{E}-01$ \\
\hline & Cf252 & $5.11 E+02$ & $2.12 E-09$ & $8.80 \mathrm{E}-21$ & $0.00 E+01$ & $0.00 \mathrm{E}+01$ & $0.00 \mathrm{E}+0.1$ & $0.00 E+01$ & $0.00 E+01$ & $0.00 E+01$ & $0.00 E+01$ & $0.00 E+01$ \\
\hline & $\mathrm{Cm} 243$ & $2.01 E+04$ & $1.77 \mathrm{E}+03$ & $1.55 E+02$ & $1.36 E+01$ & $1.20 \mathrm{E}-00$ & $1.05 \mathrm{E}-01$ & 9.23E-03 & $8.11 \mathrm{E}-04$ & $7.12 E-05$ & $6.26 \mathrm{E}-06$ & $5.50 \mathrm{E}-07$ \\
\hline & $\mathrm{Cm} 244$ & $1.07 E+05$ & $2.32 E+03$ & $5.05 E+01$ & $1.10 \mathrm{E}-00$ & $2.38 \mathrm{E}-02$ & $5.17 E-04$ & $1.12 E-05$ & $2.44 E-07$ & $5.29 \mathrm{E}-09$ & $1.15 \mathrm{E}-10$ & $2.49 \mathrm{E}-12$ \\
\hline & Cm245 & $1.32 E-04$ & $6.11 \mathrm{E}-03$ & $1.10 E-02$ & $1.49 \mathrm{E}-02$ & $1.81 \mathrm{E}-02$ & $2.06 \mathrm{E}-02$ & $2.27 \mathrm{E}-02$ & $2.43 E-02$ & $2.56 \mathrm{E}-02$ & $2.67 \mathrm{E}-02$ & $2.74 \mathrm{E}-02$ \\
\hline & Cm248 & $2.34 \mathrm{E}-02$ & $2.72 E-02$ & $2.72 E-02$ & $2.72 E-02$ & $2.72 E-02$ & $2.72 \mathrm{E}-02$ & $2.72 \mathrm{E}-02$ & $2.72 \mathrm{E}-02$ & $2.72 \mathrm{E}-02$ & $2.72 \mathrm{E}-02$ & $2.72 \mathrm{E}-02$ \\
\hline & Co58 & $7.92 \mathrm{E}-06$ & $0.00 E+01$ & $0.00 E+01$ & $0.00 \mathrm{E}+01$ & $0.00 E+01$ & $0.00 \mathrm{E}+01$ & $0.00 E+01$ & $0.00 E+01$ & $0.00 \mathrm{E}+01$ & $0.00 E+01$ & $0.00 E+01$ \\
\hline & Co 60 & $1.08 E+05$ & $2.09 E-01$ & $4.05 E-07$ & $7.85 E-13$ & $1.52 \mathrm{E}-18$ & $2.94 \mathrm{E}-24$ & $5.70 \mathrm{E}-30$ & $0.00 E+01$ & $0.00 E+01$ & $0.00 E+01$ & $0.00 \mathrm{E}+01$ \\
\hline & Cr 51 & $2.54 E-30$ & $0.00 E+01$ & $0.00 E+01$ & $0.00 E+01$ & $0.00 \mathrm{E}+01$ & $0.00 E+01$ & $0.00 E+01$ & $0.00 E+01$ & $0.00 \mathrm{E}+01$ & $0.00 E+01$ & $0.00 E+01$ \\
\hline & Cs134 & $2.15 E+04$ & $5.39 \mathrm{E}-11$ & 1.35E-25 & $0.00 E+01$ & $0.00 E+01$ & $0.00 E+01$ & $0.00 E+01$ & $0.00 E+01$ & $0.00 E+01$ & $0.00 E+01$ & $0.00 E+01$ \\
\hline \multirow{8}{*}{ 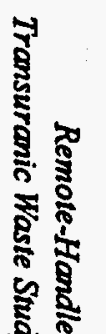 } & Cs135 & $4.58 \mathrm{E}-02$ & $4.58 \mathrm{E}-02$ & $4.58 \mathrm{E}-02$ & $4.58 \mathrm{E}-02$ & $4.58 \mathrm{E}-02$ & $4.58 \mathrm{E}-02$ & $4.58 \mathrm{E}-02$ & 4.58E-02 & 4.58E-02 & $4.58 \mathrm{E}-02$ & $4.58 \mathrm{E}-02$ \\
\hline & Cs137 & $3.28 E+06$ & $3.25 E+05$ & $3.23 E+04$ & $3.20 \mathrm{E}+03$ & $3.17 E+02$ & $3.15 E+01$ & $3.12 E-00$ & $3.10 \mathrm{E}-01$ & 3.07E-02 & 3.05E-03 & $3.02 E-04$ \\
\hline & Eu152 & $5.28 E+05$ & $2.91 E+03$ & $1.60 \mathrm{E}+01$ & $8.84 \mathrm{E}-02$ & 4.87E-04 & $2.68 E-06$ & $1.48 E-08$ & $8.15 E-11$ & $4.49 \mathrm{E}-13$ & $2.47 \mathrm{E}-15$ & $1.36 \mathrm{E}-17$ \\
\hline & Eu154 & $2.76 E+05$ & $8.64 E+01$ & $2.70 \mathrm{E}-02$ & $8.46 \mathrm{E}-06$ & 2.65E-09 & $8.29 \mathrm{E}-13$ & $2.60 \mathrm{E}-16$ & $8.12 \mathrm{E}-20$ & $2.54 \mathrm{E}-23$ & $7.96 \mathrm{E}-27$ & $2.51 \mathrm{E}-30$ \\
\hline & Eu155 & $6.78 E+04$ & $2.51 \mathrm{E}-02$ & \begin{tabular}{|c|}
$9.26 \mathrm{E}-09$ \\
\end{tabular} & $3.42 \mathrm{E}-15$ & $1.26 \mathrm{E}-21$ & \begin{tabular}{|c|}
$4.67 \mathrm{E}-28$ \\
\end{tabular} & $0.00 E+01$ & $0.00 E+01$ & $0.00 E+01$ & $0.00 E+01$ & $0.00 E+01$ \\
\hline & $\mathrm{Fe} \mathrm{55}$ & $1.44 E+02$ & 1.35E-09 & $1.27 \mathrm{E}-20$ & $2.28 \mathrm{E}-31$ & $0.00 \mathrm{E}+01$ & $0.00 \mathrm{E}+01$ & $0.00 E+01$ & $0.00 E+01$ & $0.00 \mathrm{E}+01$ & $0.00 \mathrm{E}+01$ & $0.00 \mathrm{E}+01$ \\
\hline & $\mathrm{Fe} 59$ & $4.04 E-18$ & $0.00 E+01$ & $0.00 E+01$ & $0.00 \mathrm{E}+01$ & $0.00 E+01$ & $0.00 E+01$ & $0.00 E+01$ & $0.00 E+01$ & $0.00 \mathrm{E}+01$ & $0.00 E+01$ & $0.00 \mathrm{E}+01$ \\
\hline & Fr221 & $3.28 \mathrm{E}-00$ & $7.84 E+01$ & $1.53 \mathrm{E}+02$ & $2.26 E+02$ & $2.99 E+02$ & $3.72 E+02$ & $4.43 E+02$ & $5.14 E+02$ & $5.84 E+02$ & $6.54 E+02$ & $7.23 E+02$ \\
\hline
\end{tabular}




\begin{tabular}{|c|c|c|c|c|c|c|c|c|c|}
\hline \multicolumn{8}{|c|}{ WIPP RH TRU WASTE STUDY-DATA FROM WIPP BIR REVISION 1} & \multicolumn{2}{|c|}{ UNITS: Curies } \\
\hline Isotope & $2000.0 \mathrm{yr}$ & $3000.0 \mathrm{yr}$ & $4000.0 \mathrm{yr}$ & 5000.0 yr & $6000.0 y$ & $7000.0 \mathrm{yr}$ & $8000.0 \mathrm{yr}$ & $9000.0 \mathrm{x}$ & $10000.0 \mathrm{yr}$ \\
\hline Ac225 & $1.38 E+03$ & $1.98 E+03$ & $2.52 E+03$ & $3.02 E+03$ & $3.47 \mathrm{E}+03$ & $3.88 E+03$ & $4.25 E+03$ & $4.59 E+03$ & $4.89 E+03$ \\
\hline Ac227 & $4.06 E-00$ & $5.16 E-00$ & $6.24 E-00$ & $7.30 \mathrm{E}-00$ & $8.34 \mathrm{E}-00$ & $9.36 \mathrm{E}-00$ & $1.04 E+01$ & $1.13 E+01$ & $1.23 E+01$ \\
\hline Ac228 & $7.09 E-02$ & $7.09 E-02$ & $7.09 \mathrm{E}-02$ & $7.09 E-02$ & $7.09 \mathrm{E}-02$ & $7.09 \mathrm{E}-02$ & $7.09 \mathrm{E}-02$ & $7.09 E-02$ & $7.09 \mathrm{E}-02$ \\
\hline Ag110 & $0.00 E+01$ & $0.00 E+01$ & $0.00 E+01$ & $0.00 E+01$ & $0.00 E+01$ & $0.00 E+01$ & $0.00 E+01$ & $0.00 E+01$ & $0.00 E+01$ \\
\hline Ag110m & $0.00 \mathrm{E}+01$ & $0.00 \mathrm{E}+01$ & $0.00 E+01$ & $0.00 E+01$ & $0.00 E+01$ & $0.00 E+01$ & $0.00 E+01$ & $0.00 E+01$ & $0.00 E+01$ \\
\hline Am241 & $5+02$ & $4.58 \mathrm{E}+01$ & $9.25 \mathrm{E}-00$ & $1.88 \mathrm{E}-00$ & $3.96 \mathrm{E}-01$ & $9.59 \mathrm{E}-02$ & $3.42 \mathrm{E}-02$ & $2.06 \mathrm{E}-02$ & $1.68 \mathrm{E}-02$ \\
\hline Am243 & $2.56 \mathrm{E}-01$ & $2.33 E-01$ & $2.12 E-01$ & $1.93 \mathrm{E}-01$ & $1.76 \mathrm{E}-01$ & $1.60 \mathrm{E}-01$ & $1.46 E-01$ & $1.33 \mathrm{E}-01$ & $1.21 \mathrm{E}-01$ \\
\hline Am245 & $0.00 E+01$ & $0.00 E+01$ & $0.00 E+01$ & $0.00 E+01$ & $0.00 E+01$ & $0.00 E+01$ & $0.00 E+01$ & $0.00 E+01$ & $0.00 \mathrm{E}+01$ \\
\hline At217 & & +03 & +03 & $E+03$ & +03 & & $5 E+03$ & $4.59 E+03$ & $4.89 E+03$ \\
\hline Ba137m & & $2.42 E-24$ & +01 & $E+01$ & $0.00 \mathrm{E}+01$ & $0.00 E+01$ & $0.00 \mathrm{E}+01$ & $0.00 E+01$ & $0.00 E+01$ \\
\hline Bi210 & $7.21 \mathrm{E}$ & $1.51 \mathrm{E}-01$ & & & 4.67E-01 & $5.87 E-01$ & $7.12 \mathrm{E}-01$ & $8.40 E-01$ & $9.72 \mathrm{E}-01$ \\
\hline$\overline{B i 21}$ & & & & & -00 & -00 & $E+01$ & $3 E+01$ & +01 \\
\hline & & & & & & & $E-02$ & $7.09 \mathrm{E}-02$ & $7.09 \mathrm{E}-02$ \\
\hline & & & $2.52 \mathrm{E}$ & $3.02 E+03$ & $E+03$ & $E+03$ & $E+03$ & $4.59 E+03$ & $4.89 \mathrm{E}+03$ \\
\hline Bi214 & & & & & E-01 & -01 & $E-01$ & $\mathrm{EE}-01$ & $E-01$ \\
\hline & & 01 & +01 & 01 & +01 & +01 & +01 & $E+01$ & $0 E+01$ \\
\hline C 14 & & & & +02 & +02 & $6.47 E+02$ & $5.74 E+02$ & $8 E+02$ & $0 \mathrm{E}+02$ \\
\hline Cd113 & & 22 & & & & $5.01 E-22$ & $5.01 \mathrm{E}-22$ & $\overline{1 E-22}$ & E-22 \\
\hline & & & & & +01 & +01 & $E+01$ & $E+01$ & $E+01$ \\
\hline & & & & & +01 & $=+01$ & $E+01$ & $00 E+01$ & $0.00 \mathrm{E}+01$ \\
\hline C\{249 & & $2.15 \mathrm{E}-03$ & $2.97 E-04$ & $4.11 E-05$ & 5.69E-06 & $E-07$ & $E-07$ & $51 E-08$ & $2.08 \mathrm{E}-09$ \\
\hline C252 & & & & & $0.00 E+01$ & & +01 & $E+01$ & $E+01$ \\
\hline & & & & & +01 & +01 & $E+01$ & $\bar{E}+01$ & $\overline{0 E+01}$ \\
\hline & & 01 & +01 & +01 & +01 & $0.00 E+01$ & $0.00 E+01$ & $0.00 \mathrm{E}+01$ & $0 E+01$ \\
\hline $\mathrm{Cm} 245$ & & -02 & -02 & -02 & -02 & $1.98 \mathrm{E}-02$ & $1.82 \mathrm{E}-02$ & $68 E-02$ & $5 E-02$ \\
\hline Cm248 & & & & & & & -02 & $68 \mathrm{E}-02$ & $7 E-02$ \\
\hline Co 58 & & & & +01 & $0.00 \mathrm{E}+01$ & $E+01$ & $0.00 E+01$ & $00 E+01$ & $0.00 E+01$ \\
\hline & & $\overline{401}$ & $0.00 E+01$ & $0.00 E+01$ & $0.00 E+01$ & $0.00 E+01$ & $0.00 E+01$ & $0.00 E+01$ & $0.00 E+01$ \\
\hline Cr 51 & +01 & $0.00 E+01$ & $0.00 E+01$ & $0.00 E+01$ & $0.00 E+01$ & $0.00 E+01$ & $0.00 E+01$ & $00 \mathrm{E}+01$ & $0.00 E+01$ \\
\hline Cs134 & 0.00 & $E+01$ & & & $0.00 E+01$ & & $0.00 E+01$ & $E+01$ & $E+01$ \\
\hline Cs135 & & & & & 4.57E-02 & $4.57 \mathrm{E}-02$ & $4.57 E-02$ & $4.57 E-02$ & $4.57 E-02$ \\
\hline & & $E-24$ & $0.00 E+01$ & $0.00 \mathrm{E}+01$ & $0.00 E+01$ & $0.00 E+01$ & $0.00 E+01$ & $0.00 E+01$ & $0.00 E+01$ \\
\hline Eu152 & $0.00 E+01$ & $0.00 E+01$ & $0.00 E+01$ & $0.00 \mathrm{E}+01$ & $0.00 E+01$ & $0.00 E+01$ & $0.00 E+01$ & $0.00 E+01$ & $0.00 E+01$ \\
\hline Eu154 & $0.00 E+01$ & $0.00 E+01$ & $0.00 E+01$ & $0.00 E+01$ & $0.00 E+01$ & $0.00 E+01$ & $0.00 E+01$ & $0.00 E+01$ & $0.00 \mathrm{E}+01$ \\
\hline Eu155 & & $0.00 E+01$ & & & $0.00 E+01$ & $0.00 E+01$ & $0.00 E+01$ & $0.00 E+01$ & $0.00 E+01$ \\
\hline $\mathrm{Fe} 55$ & & $0.00 E+01$ & & $0.00 \mathrm{E}+01$ & $0.00 E+01$ & $0.00 E+01$ & $0.00 E+01$ & $0.00 E+01$ & $0.00 E+01$ \\
\hline Fe 59 & $0.00 \mathrm{E}+01$ & $0.00 E+01$ & $0.00 E+01$ & $0.00 E+01$ & $0.00 E+01$ & $0.00 E+01$ & $0.00 E+01$ & $0.00 E+01$ & $0.00 \mathrm{E}+01$ \\
\hline
\end{tabular}


\begin{tabular}{|l|l|l|l|l|l|l|l|l|l|l|l|}
\hline Isotope & Initial & $100.0 \mathrm{yr}$ & $200.0 \mathrm{yr}$ & $300.0 \mathrm{yr}$ & $400.0 \mathrm{yr}$ & $500.0 \mathrm{yr}$ & $600.0 \mathrm{yr}$ & $700.0 \mathrm{yr}$ & $800.0 \mathrm{yr}$ & $900.0 \mathrm{yr}$ & $1000.0 \mathrm{yr}$ \\
\hline
\end{tabular} \begin{tabular}{|l|l|l|l|l|l|l|l|l|l|l|l|}
\hline F 223 & $2.10 E-03$ & $2.48 E-02$ & $2.72 E-02$ & $2.89 E-02$ & $3.05 E-02$ & $3.21 E-02$ & $3.36 E-02$ & $3.52 E-02$ & $3.68 E-02$ & $3.84 E-02$ & $3.99 E-02$ \\
\hline
\end{tabular} \begin{tabular}{|l|l|l|l|l|l|l|l|l|l|l|l|l|}
\hline Gd152 & $0.00 E+01$ & $1.81 E-08$ & $1.82 E-08$ & $1.82 E-08$ & $1.82 E-08$ & $1.82 E-08$ & $1.82 E-08$ & $1.82 E-08$ & $1.82 E-08$ & $1.82 E-08$ & $1.82 E-08$ \\
\hline$H$
\end{tabular} \begin{tabular}{|l|l|l|l|l|l|l|l|l|l|l|l|}
\hline $\mathrm{H} 3$ & $8.23 \mathrm{E}+02$ & $2.98 \mathrm{E}-00$ & $1.08 \mathrm{E}-02$ & $3.89 \mathrm{E}-05$ & $1.41 \mathrm{E}-07$ & $5.09 \mathrm{E}-10$ & $1.84 \mathrm{E}-12$ & $6.66 \mathrm{E}-15$ & $2.41 \mathrm{E}-17$ & $8.72 \mathrm{E}-20$ & $3.15 \mathrm{E}-22$ \\
\hline
\end{tabular} \begin{tabular}{|l|l|l|l|l|l|l|l|l|l|l|l|}
\hline Kr 85 & $9.58 E+02$ & $1.49 E-00$ & $2.32 E-03$ & $3.60 E-06$ & $5.60 E-09$ & $8.71 E-12$ & $1.35 E-14$ & $2.10 E-17$ & $3.27 E-20$ & $5.09 E-23$ & $7.91 E-26$ \\
\hline
\end{tabular} \begin{tabular}{|l|l|l|l|l|l|l|l|l|l|l|l|}
\hline $\operatorname{Mn} 54$ & $2.76 E+01$ & $0.00 E+01$ & $0.00 E+01$ & $0.00 E+01$ & $0.00 E+01$ & $0.00 E+01$ & $0.00 E+01$ & $0.00 E+01$ & $0.00 E+01$ & $0.00 E+01$ & $0.00 E+01$ \\
\hline
\end{tabular} \begin{tabular}{|l|l|l|l|l|l|l|l|l|l|l|l|l|l}
\hline $\mathrm{Nb} 95$ & $9.90 \mathrm{E}+01$ & $0.00 \mathrm{E}+01$ & $0.00 \mathrm{E}+01$ & $0.00 \mathrm{E}+01$ & $0.00 \mathrm{E}+01$ & $0.00 \mathrm{E}+01$ & $0.00 \mathrm{E}+01$ & $0.00 \mathrm{E}+01$ & $0.00 \mathrm{E}+01$ & $0.00 \mathrm{E}+01$ & $0.00 \mathrm{E}+01$ \\
\hline
\end{tabular} \begin{tabular}{|l|l|l|l|l|l|l|l|l|l|l|l|l}
\hline $\mathrm{Nb} 95 \mathrm{~m}$ & $3.41 \mathrm{E}-01$ & $0.00 \mathrm{E}+01$ & $0.00 \mathrm{E}+01$ & $0.00 \mathrm{E}+01$ & $0.00 \mathrm{E}+01$ & $0.00 \mathrm{E}+01$ & $0.00 \mathrm{E}+01$ & $0.00 \mathrm{E}+01$ & $0.00 \mathrm{E}+01$ & $0.00 \mathrm{E}+01$ & $0.00 \mathrm{E}+01$ \\
\hline
\end{tabular} \begin{tabular}{|l|l|l|l|l|l|l|l|l|l|l|l|}
\hline $\mathrm{Nd} 144$ & $0.00 \mathrm{E}+01$ & $2.08 \mathrm{E}-12$ & $2.08 \mathrm{E}-12$ & $2.08 \mathrm{E}-12$ & $2.08 \mathrm{E}-12$ & $2.08 \mathrm{E}-12$ & $2.08 \mathrm{E}-12$ & $2.08 \mathrm{E}-12$ & $2.08 \mathrm{E}-12$ & $2.08 \mathrm{E}-12$ & $2.08 \mathrm{E}-12$ \\
\hline
\end{tabular} \begin{tabular}{|l|l|l|l|l|l|l|l|l|l|l|l|l|}
\hline $\mathrm{Ni} 63$ & $5.03 \mathrm{E}+02$ & $2.52 \mathrm{E}+02$ & $1.26 \mathrm{E}+02$ & $6.30 \mathrm{E}+01$ & $3.15 \mathrm{E}+01$ & $1.58 \mathrm{E}+01$ & $7.89 \mathrm{E}-00$ & $3.95 \mathrm{E}-00$ & $1.98 \mathrm{E}-00$ & $9.88 \mathrm{E}-01$ & $4.94 \mathrm{E}-01$ \\
\hline
\end{tabular} \begin{tabular}{|l|l|l|l|l|l|l|l|l|l|l|l|}
\hline Np237 & $1.18 \mathrm{E}-01$ & $2.84 \mathrm{E}-01$ & $4.27 \mathrm{E}-01$ & $5.49 \mathrm{E}-01$ & $6.53 \mathrm{E}-01$ & $7.41 \mathrm{E}-01$ & $8.16 \mathrm{E}-01$ & $8.81 \mathrm{E}-01$ & $9.35 \mathrm{E}-01$ & $9.82 \mathrm{E}-01$ & $1.02 \mathrm{E}-00$ \\
\hline
\end{tabular} \begin{tabular}{|l|l|l|l|l|l|l|l|l|l|l|l|}
\hline Np239 & $1.22 E-01$ & $2.90 E-01$ & $3.02 E-01$ & $3.01 E-01$ & $2.98 E-01$ & $2.95 E-01$ & $2.92 E-01$ & $2.90 E-01$ & $2.87 E-01$ & $2.84 E-01$ & $2.81 E-01$ \\
\hline
\end{tabular} \begin{tabular}{|l|l|l|l|l|l|l|l|l|l|l|l|}
\hline $\mathrm{Np} 240$ & $1.78 \mathrm{E}-12$ & $2.79 \mathrm{E}-11$ & $5.39 \mathrm{E}-11$ & $7.98 \mathrm{E}-11$ & $1.06 \mathrm{E}-10$ & $1.32 \mathrm{E}-10$ & $1.58 \mathrm{E}-10$ & $1.84 \mathrm{E}-10$ & $2.09 \mathrm{E}-10$ & $2.35 \mathrm{E}-10$ & $2.61 \mathrm{E}-10$ \\
\hline $\mathrm{N} 240$ & 1 & &
\end{tabular} \begin{tabular}{|l|l|l|l|l|l|l|l|l|l|l|l|}
\hline $\mathrm{Np} 240 \mathrm{~m}$ & $1.62 \mathrm{E}-09$ & $2.33 \mathrm{E}-08$ & $4.49 \mathrm{E}-08$ & $6.65 \mathrm{E}-08$ & $8.81 \mathrm{E}-08$ & $1.10 \mathrm{E}-07$ & $1.31 \mathrm{E}-07$ & $1.53 \mathrm{E}-07$ & $1.75 \mathrm{E}-07$ & $1.96 \mathrm{E}-07$ & $2.18 \mathrm{E}-07$ \\
\hline
\end{tabular}

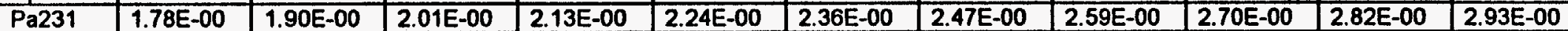
\begin{tabular}{|l|l|l|l|l|l|l|l|l|l|l|l|}
\hline $\mathrm{Pa} 233$ & $1.18 \mathrm{E}-01$ & $2.84 \mathrm{E}-01$ & $4.27 \mathrm{E}-01$ & $5.49 \mathrm{E}-01$ & $6.53 \mathrm{E}-01$ & $7.41 \mathrm{E}-01$ & $8.16 \mathrm{E}-01$ & $8.81 \mathrm{E}-01$ & $9.35 \mathrm{E}-01$ & $9.82 \mathrm{E}-01$ & $1.02 \mathrm{E}-00$ \\
\hline $\mathrm{Pa} 34$ & 1 & &
\end{tabular}

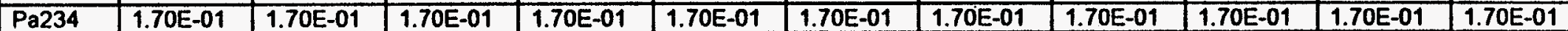

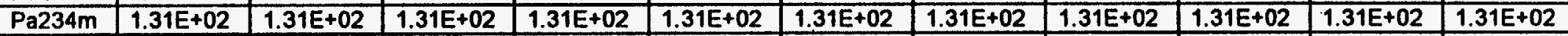
\begin{tabular}{|l|l|l|l|l|l|l|l|l|l|l|l|}
\hline $\mathrm{Pb209}$ & $3.28 \mathrm{E}-00$ & $7.84 \mathrm{E}+01$ & $1.53 \mathrm{E}+02$ & $2.26 \mathrm{E}+02$ & $2.99 \mathrm{E}+02$ & $3.72 \mathrm{E}+02$ & $4.43 \mathrm{E}+02$ & $5.14 \mathrm{E}+02$ & $5.84 \mathrm{E}+02$ & $6.54 \mathrm{E}+02$ & $7.23 \mathrm{E}+02$ \\
\hline
\end{tabular} \begin{tabular}{|l|l|l|l|l|l|l|l|l|l|l|l|l|}
\hline $\mathrm{Pb} 10$ & $4.09 \mathrm{E}-10$ & $3.08 \mathrm{E}-05$ & $269 \mathrm{E}-04$ & $865 \mathrm{E}-04$ & $188 \mathrm{E}-03$ & $3.34 \mathrm{E}-03$ & $5.23 \mathrm{E}-03$ & $7.55 \mathrm{E}-03$ & $1.03 \mathrm{E}-02$ & $1.34 \mathrm{E}-02$ & $1.69 \mathrm{E}-02$ \\
\hline
\end{tabular} \begin{tabular}{|l|l|l|l|l|l|l|l|l|l|l|l|}
\hline $\mathrm{Pb211}$ & $1.46 \mathrm{E}-01$ & $1.80 \mathrm{E}-00$ & $1.97 \mathrm{E}-00$ & $2.09 \mathrm{E}-00$ & $2.21 \mathrm{E}-00$ & $2.32 \mathrm{E}-00$ & $2.44 \mathrm{E}-00$ & $2.55 \mathrm{E}-00$ & $2.67 \mathrm{E}-00$ & $2.78 \mathrm{E}-00$ & $2.89 \mathrm{E}-00$ \\
\hline
\end{tabular} \begin{tabular}{|l|l|l|l|l|l|l|l|l|l|l|l|}
\hline $\mathrm{Pb} 212$ & $9.03 \mathrm{E}+01$ & $4.43 \mathrm{E}+01$ & $1.64 \mathrm{E}+01$ & $6.13 \mathrm{E}-00$ & $2.32 \mathrm{E}-00$ & $9.03 \mathrm{E}-01$ & $3.79 \mathrm{E}-01$ & $1.85 \mathrm{E}-01$ & $1.13 \mathrm{E}-01$ & $8.66 \mathrm{E}-02$ & $7.67 \mathrm{E}-02$ \\
\hline
\end{tabular} \begin{tabular}{|l|l|l|l|l|l|l|l|l|l|l|l|}
\hline $\mathrm{Pb} 214$ & $7.23 \mathrm{E}-09$ & $6.31 \mathrm{E}-05$ & $3.98 \mathrm{E}-04$ & $1.12 \mathrm{E}-03$ & $2.28 \mathrm{E}-03$ & $3.88 \mathrm{E}-03$ & $5.91 \mathrm{E}-03$ & $8.36 \mathrm{E}-03$ & $1.12 \mathrm{E}-02$ & $1.45 \mathrm{E}-02$ & $1.81 \mathrm{E}-02$ \\
\hline
\end{tabular} \begin{tabular}{|l|l|l|l|l|l|l|l|l|l|l|l|}
\hline $\mathrm{Pd} 107$ & $6.77 \mathrm{E}-03$ & $6.77 \mathrm{E}-03$ & $6.77 \mathrm{E}-03$ & $6.77 \mathrm{E}-03$ & $6.77 \mathrm{E}-03$ & $6.77 \mathrm{E}-03$ & $6.77 \mathrm{E}-03$ & $6.77 \mathrm{E}-03$ & $6.77 \mathrm{E}-03$ & $6.77 \mathrm{E}-03$ & $6.77 \mathrm{E}-03$ \\
\hline
\end{tabular} \begin{tabular}{|l|l|l|l|l|l|l|l|l|l|l|l|l|}
\hline Pm147 & $4.10 E+04$ & $1.37 E-07$ & $4.59 E-19$ & $1.60 E-30$ & $0.00 E+01$ & $0.00 E+01$ & $0.00 E+01$ & $0.00 E+01$ & $0.00 E+01$ & $0.00 E+01$ & $0.00 E+01$ \\
\hline
\end{tabular}

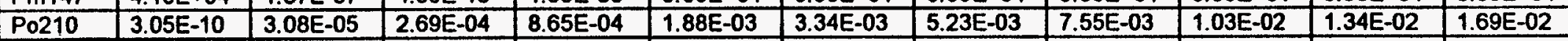
\begin{tabular}{|l|l|l|l|l|l|l|l|l|l|l|l|l|l|}
\hline $\mathrm{P} 0211$ & $3.98 \mathrm{E}-04$ & $4.94 \mathrm{E}-03$ & $5.43 \mathrm{E}-03$ & $5.75 \mathrm{E}-03$ & $6.07 \mathrm{E}-03$ & $6.39 \mathrm{E}-03$ & $6.70 \mathrm{E}-03$ & $7.02 \mathrm{E}-03$ & $7.33 \mathrm{E}-03$ & $7.65 \mathrm{E}-03$ & $7.96 \mathrm{E}-03$ \\
\hline
\end{tabular} \begin{tabular}{l|l|l|l|l|l|l|l|l|l|l|l|}
\hline P0212 & $5.78 E+01$ & $2.84 E+01$ & $1.05 E+01$ & $3.93 E-00$ & $1.48 E-00$ & $5.79 E-01$ & $2.43 E-01$ & $1.19 E-01$ & $7.25 E-02$ & $5.55 E-02$ & $4.91 E-02$ \\
\hline
\end{tabular} \begin{tabular}{|l|l|l|l|l|l|l|l|l|l|l|l|}
\hline $\mathrm{P} 0213$ & $3.21 \mathrm{E}-00$ & $7.67 \mathrm{E}+01$ & $1.49 \mathrm{E}+02$ & $2.22 \mathrm{E}+02$ & $2.93 \mathrm{E}+02$ & $3.64 \mathrm{E}+02$ & $4.34 \mathrm{E}+02$ & $5.03 \mathrm{E}+02$ & $5.72 \mathrm{E}+02$ & $6.40 \mathrm{E}+02$ & $7.08 \mathrm{E}+02$ \\
\hline
\end{tabular} \begin{tabular}{|l|l|l|l|l|l|l|l|l|l|l|l|l|}
\hline & &
\end{tabular} \begin{tabular}{|l|l|l|l|l|l|l|l|l|l|l|l|}
\hline P0214 & $7.23 E-09$ & $6.31 E-05$ & $3.98 E-04$ & $1.12 E-03$ & $2.28 E-03$ & $3.87 E-03$ & $5.91 E-03$ & $8.36 E-03$ & $1.12 E-02$ & $1.45 E-02$ & $1.81 E-02$ \\
\hline P0215 & $1.46 E-01$ & $1.80 E-00$ & $1.97 E-00$ & $2.09 E-00$ & $2.21 E-00$ & $2.32 E-00$ & $2.44 E-00$ & $2.55 E-00$ & $2.67 E-00$ & $2.78 E-00$ & $2.89 E-00$ \\
\hline$P 0216$ & $9.03 E+01$ & $4.43 E+01$ & $1.64 E+01$ & 6.00 &
\end{tabular} \begin{tabular}{|l|l|l|l|l|l|l|l|l|l|l|l|}
\hline $\mathrm{P} 0216$ & $9.03 \mathrm{E}+01$ & $4.43 \mathrm{E}+01$ & $1.64 \mathrm{E}+01$ & $6.13 \mathrm{E}-00$ & $2.32 \mathrm{E}-00$ & $9.03 \mathrm{E}-01$ & $3.79 \mathrm{E}-01$ & $1.85 \mathrm{E}-01$ & $1.13 \mathrm{E}-01$ & $8.66 \mathrm{E}-02$ & $7.67 \mathrm{E}-02$ \\
\hline
\end{tabular} \begin{tabular}{|l|l|l|l|l|l|l|l|l|l|l|l|}
\hline P0218 & $7.23 E-09$ & $6.31 E-05$ & $3.98 E-04$ & $1.12 E-03$ & $2.28 E-03$ & $3.88 E-03$ & $5.91 E-03$ & $8.36 E-03$ & $1.12 E-02$ & $1.45 E-02$ & $1.81 E-02$ \\
\hline
\end{tabular} \begin{tabular}{|l|l|l|l|l|l|l|l|l|l|l|l|}
\hline Pr144 & $5.58 E+03$ & $0.00 E+01$ & $0.00 E+01$ & $0.00 E+01$ & $0.00 E+01$ & $0.00 E+01$ & $0.00 E+01$ & $0.00 E+01$ & $0.00 E+01$ & $0.00 E+01$ & $0.00 E+01$ \\
\hline
\end{tabular} \begin{tabular}{|l|l|l|l|l|l|l|l|l|l|l|l|}
\hline Pu238 & $3.53 E+04$ & $1.60 E+04$ & $7.27 E+03$ & $3.30 E+03$ & $1.50 E+03$ & $6.79 E+02$ & $3.08 E+02$ & $1.40 E+02$ & $6.34 E+01$ & $2.88 E+01$ & $1.30 E+01$ \\
\hline
\end{tabular}

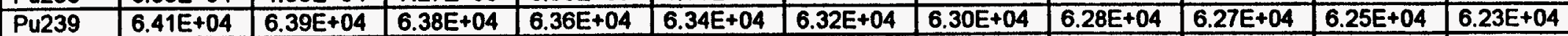
\begin{tabular}{|l|l|l|l|l|l|l|l|l|l|l|l|}
\hline $\mathrm{P} 240$ & $1.74 \mathrm{E}+03$ & $201 \mathrm{E}+03$ & $1.99 \mathrm{E}+03$ & $1.97 \mathrm{E}+03$ & $1.95 \mathrm{E}+03$ & $1.93 \mathrm{E}+03$ & $1.91 \mathrm{E}+03$ & $1.89 \mathrm{E}+03$ & $1.87 \mathrm{E}+03$ & $1.85 \mathrm{E}+03$ & $1.83 \mathrm{E}+03$ \\
\hline
\end{tabular} \begin{tabular}{|l|l|l|l|l|l|l|l|l|l|l|l|}
\hline Pu241 & $9.06 \mathrm{E}+03$ & $7.23 \mathrm{E}+01$ & $5.86 \mathrm{E}-01$ & $1.87 \mathrm{E}-02$ & $1.75 \mathrm{E}-02$ & $2.01 \mathrm{E}-02$ & $2.23 \mathrm{E}-02$ & $2.40 \mathrm{E}-02$ & $2.54 \mathrm{E}-02$ & $2.65 \mathrm{E}-02$ & $2.73 \mathrm{E}-02$ \\
\hline
\end{tabular}

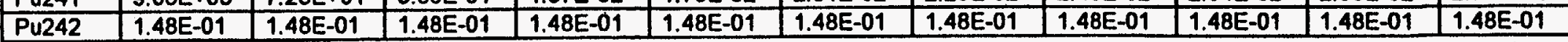




\begin{tabular}{|c|c|c|c|c|c|c|c|c|c|}
\hline WIPP F & U WAS & IOUT- & A FROW & 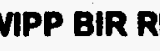 & ION 1 & & & & \\
\hline Isotope & $2000.0 y x$ & $3000.0 \mathrm{yr}$ & $4000.0 \mathrm{yr}$ & $5000.0 \mathrm{yr}$ & $6000.0 y$ & $7000.0 y r$ & $8000.0 y$ & $8000.0 \mathrm{y}$ & $10000.0 \mathrm{yr}$ \\
\hline Fr221 & $1.38 E+03$ & $1.98 E+03$ & $2.52 E+03$ & $3.02 E+03$ & $3.47 E+03$ & $3.88 E+03$ & $4.25 E+03$ & $4.59 E+03$ & $4.89 E+03$ \\
\hline Fr223 & $5.60 \mathrm{E}-02$ & $7.12 \mathrm{E}-02$ & \begin{tabular}{|l}
$8.62 E-02$ \\
\end{tabular} & $1.01 \mathrm{E}-01$ & $1.15 E-01$ & $1.29 \mathrm{E}-01$ & $1.43 E-01$ & $1.56 \mathrm{E}-01$ & $1.70 \mathrm{E}-01$ \\
\hline Gd152 & $1.82 \mathrm{E}-08$ & $1.82 E-08$ & $1.82 E-08$ & $1.82 E-08$ & $1.82 E-08$ & $1.82 E-08$ & $1.82 E-08$ & $1.82 E-08$ & $1.82 E-08$ \\
\hline $\mathrm{H}_{3}$ & $0.00 E+01$ & $0.00 E+01$ & $0.00 E+01$ & $0.00 E+01$ & $0.00 E+01$ & $0.00 E+01$ & $0.00 E+01$ & $0.00 E+01$ & $0.00 E+01$ \\
\hline Kr 85 & $0.00 E+01$ & $0.00 E+01$ & $0.00 E+01$ & $0.00 E+01$ & $0.00 E+01$ & $0.00 E+01$ & $0.00 E+01$ & $0.00 E+01$ & $0.00 E+01$ \\
\hline Mn 54 & $0.00 E+01$ & $0.00 E+01$ & $0.00 E+01$ & $0.00 E+01$ & $0.00 E+01$ & $0.00 E+01$ & $0.00 E+01$ & $0.00 E+01$ & $0.00 E+01$ \\
\hline $\mathrm{Nb} 95$ & $0.00 E+01$ & $0.00 E+01$ & $0.00 E+01$ & $0.00 E+01$ & $0.00 E+01$ & $0.00 E+01$ & $0.00 E+01$ & $0.00 \mathrm{E}+01$ & $0.00 E+01$ \\
\hline $\mathrm{Nb} 95 \mathrm{~m}$ & $0.00 E+01$ & $0.00 E+01$ & $0.00 E+01$ & $0.00 E+01$ & $0.00 E+01$ & $0.00 E+01$ & $0.00 E+01$ & $0.00 E+01$ & $0.00 E+01$ \\
\hline Nd144 & $2.08 \mathrm{E}-12$ & $2.08 \mathrm{E}-12$ & $2.08 E-12$ & $2.08 \mathrm{E}-12$ & $2.08 \mathrm{E}-12$ & $2.08 \mathrm{E}-12$ & $2.08 \mathrm{E}-12$ & $2.08 \mathrm{E}-12$ & $2.08 \mathrm{E}-12$ \\
\hline Ni 63 & $4.86 E-04$ & $4.78 E-07$ & $4.70 E-10$ & $4.62 \mathrm{E}-13$ & $4.54 E-16$ & $4.46 E-19$ & $4.38 \mathrm{E}-22$ & $4.31 E-25$ & $4.23 E-28$ \\
\hline Np237 & $1.20 \mathrm{E}-00$ & $1.24 \mathrm{E}-00$ & $1.25 \mathrm{E}-00$ & $1.25 \mathrm{E}-00$ & $1.25 \mathrm{E}-00$ & $1.25 \mathrm{E}-00$ & $1.25 \mathrm{E}-00$ & $1.25 E-00$ & $1.25 \mathrm{E}-00$ \\
\hline Np239 & & $2.33 E-01$ & $2.12 \mathrm{E}-01$ & $1.93 \mathrm{E}-01$ & $1.76 \mathrm{E}-01$ & $1.60 \mathrm{E}-01$ & $1.46 \mathrm{E}-01$ & $1.33 \mathrm{E}-01$ & \begin{tabular}{|l}
$.21 E-01$ \\
\end{tabular} \\
\hline Np240 & $5.20 \mathrm{E}-10$ & $7.78 E-10$ & 1.04E-09 & $1.29 \mathrm{E}-09$ & $1.55 \mathrm{E}-09$ & $1.81 \mathrm{E}-09$ & $2.06 E-09$ & $2.32 E-09$ & $2.57 E-09$ \\
\hline $\mathrm{Np240m}$ & $4.33 \mathrm{E}-07$ & $6.49 \mathrm{E}-07$ & \begin{tabular}{|l}
$8.63 \mathrm{E}-07$ \\
\end{tabular} & $1.08 \mathrm{E}-06$ & $1.29 \mathrm{E}-06$ & $1.51 E-06$ & $1.72 \mathrm{E}-06$ & $3 \mathrm{E}-06$ & $E-06$ \\
\hline Pa231 & $4.06 E-00$ & $5.16 \mathrm{E}-00$ & $6.24 E-00$ & -00 & $8.34 E-00$ & $9.36 \mathrm{E}-00$ & $1.04 E+01$ & $1.13 E+01$ & $1.23 E+01$ \\
\hline Pa233 & $1.20 \mathrm{E}-00$ & $1.24 \mathrm{E}-00$ & $\begin{array}{l}1.25 E-00 \\
\end{array}$ & $1.25 E-00$ & $1.25 \mathrm{E}-00$ & $1.25 \mathrm{E}-00$ & $1.25 \mathrm{E}-00$ & $1.25 E-00$ & $1.25 \mathrm{E}-00$ \\
\hline Pa234 & $1.70 \mathrm{E}-01$ & $1.70 \mathrm{E}-01$ & $1.70 \mathrm{E}-01$ & 1.70 E-01 & $1.70 \mathrm{E}-01$ & 1.70 E-01 & $1.70 E-01$ & $1.70 E-01$ & 1.70 E-01 \\
\hline Pa234m & $1.31 E+02$ & $1.31 E+02$ & +02 & $1.31 E+02$ & $1.31 E+02$ & $1.31 E+02$ & $1.31 E+02$ & $1.31 \mathrm{E}+02$ & $E+02$ \\
\hline $\mathrm{Pb209}$ & $1.38 E+03$ & $1.98 E+03$ & $2.52 E+03$ & +03 & $3.47 E+03$ & $3.88 E+03$ & $4.25 \mathrm{E}+03$ & $4.59 E+03$ & $4.89 E+03$ \\
\hline $\mathrm{Pb} 210$ & $7.21 E-02$ & \begin{tabular}{|c|}
$1.51 \mathrm{E}-01$ \\
\end{tabular} & $2.46 \mathrm{E}-01$ & $3.52 \mathrm{E}-01$ & 4.67E-01 & \begin{tabular}{|l}
$5.87 \mathrm{E}-01$ \\
\end{tabular} & $7.12 \mathrm{E}-01$ & $8.40 E-01$ & $9.72 \mathrm{E}-01$ \\
\hline $\mathrm{Pb} 211$ & $4.06 \mathrm{E}-00$ & $5.16 \mathrm{E}-00$ & $6.24 \mathrm{E}-00$ & $E-00$ & $8.34 \mathrm{E}-00$ & $9.36 \mathrm{E}-00$ & $4 E+01$ & $1.13 \mathrm{E}+01$ & $E+01$ \\
\hline $\mathrm{Pb212}$ & $7.09 \mathrm{E}-02$ & 7.09 & $7.09 \mathrm{E}-02$ & $E-02$ & 7.09 E-02 & $7.09 \mathrm{E}-02$ & \begin{tabular}{|c|}
$7.09 \mathrm{E}-02$ \\
\end{tabular} & $7.09 \mathrm{E}-02$ & $7.09 \mathrm{E}-02$ \\
\hline $\mathrm{Pb214}$ & $7.22 \mathrm{E}-02$ & $1.51 E-01$ & $2.46 \mathrm{E}-01$ & $3.52 \mathrm{E}-01$ & 4.67E-01 & 5.87E-01 & $7.12 \mathrm{E}-01$ & 8.41E-01 & $9.72 E-01$ \\
\hline Pd107 & $6.77 \mathrm{E}-03$ & $\begin{array}{l}6.77 \mathrm{E}-03 \\
\end{array}$ & \begin{tabular}{|l|}
$6.77 E-03$ \\
\end{tabular} & $6.77 \mathrm{E}-03$ & $6.77 E-03$ & $6.76 E-03$ & $6.76 \mathrm{E}-03$ & $6.76 \mathrm{E}-03$ & $6.76 \mathrm{E}-03$ \\
\hline Pm147 & $0.00 E+01$ & & & $E+01$ & $0.00 E+01$ & $0.00 E+01$ & $0.00 \mathrm{E}+01$ & $0.00 \mathrm{E}+01$ & $0.00 E+01$ \\
\hline Po210 & $7.21 \mathrm{E}-02$ & -01 & $2.46 \mathrm{E}-01$ & -01 & $4.67 \mathrm{E}-01$ & $5.87 \mathrm{E}-01$ & $7.12 E-01$ & \begin{tabular}{|c|}
$8.40 E-01$ \\
\end{tabular} & $9.72 \mathrm{E}-01$ \\
\hline Po211 & $1.12 E-02$ & $1.42 \mathrm{E}-02$ & $1.72 E-02$ & $2.01 E-02$ & $2.29 E-02$ & $2.57 \mathrm{E}-02$ & $2.85 \mathrm{E}-02$ & $3.12 E-02$ & $3.38 \mathrm{E}-02$ \\
\hline Po212 & $4.54 \mathrm{E}-02$ & $4.54 \mathrm{E}-02$ & $4.54 \mathrm{E}-02$ & $4.54 E-02$ & $4.54 \mathrm{E}-02$ & $4.54 \mathrm{E}-02$ & $4.54 \mathrm{E}-02$ & $4.54 E-02$ & $4.54 \mathrm{E}-02$ \\
\hline P0213 & $1.35 E+03$ & $1.94 E+03$ & $2.47 E+03$ & $2.95 E+03$ & $3.39 E+03$ & $3.79 E+03$ & $4.16 E+03$ & $4.49 E+03$ & $4.79 E+03$ \\
\hline Po214 & $7.21 \mathrm{E}-02$ & $1.51 \mathrm{E}-01$ & $2.46 \mathrm{E}-01$ & \begin{tabular}{|l|}
$3.52 \mathrm{E}-01$ \\
\end{tabular} & $4.67 \mathrm{E}-01$ & 5.87E-01 & $7.12 \mathrm{E}-01$ & $8.40 \mathrm{E}-01$ & $9.72 E-01$ \\
\hline P0215 & $4.06 E-00$ & $5.16 \mathrm{E}-00$ & $6.24 \mathrm{E}-00$ & $7.30 E-00$ & 8.34E-00 & $9.36 \mathrm{E}-00$ & $1.04 E+01$ & $1.13 E+01$ & $1.23 E+01$ \\
\hline Po216 & $7.09 \mathrm{E}-02$ & $7.09 \mathrm{E}-02$ & $7.09 \mathrm{E}-02$ & $7.09 \mathrm{E}-02$ & $7.09 E-02$ & $7.09 \mathrm{E}-02$ & $7.09 \mathrm{E}-02$ & $7.09 E-02$ & $7.09 \mathrm{E}-02$ \\
\hline Po218 & $7.22 \mathrm{E}-02$ & $1.51 E-01$ & $2.46 \mathrm{E}-01$ & $3.52 E-01$ & $4.67 E-01$ & $5.88 \mathrm{E}-01$ & $7.12 E-01$ & $8.41 E-01$ & $9.72 \mathrm{E}-01$ \\
\hline Pr144 & $0.00 E+01$ & $0.00 E+01$ & $0.00 E+01$ & $0.00 E+01$ & $0.00 E+01$ & $0.00 \mathrm{E}+01$ & $0.00 E+01$ & $0.00 E+01$ & $0.00 E+01$ \\
\hline Pu238 & $4.82 \mathrm{E}-03$ & $1.78 \mathrm{E}-06$ & $6.59 \mathrm{E}-10$ & $2.43 E-13$ & $9.00 \mathrm{E}-17$ & $3.33 \mathrm{E}-20$ & $1.23 E-23$ & $4.54 E-27$ & $1.60 \mathrm{E}-30$ \\
\hline Pu239 & $6.05 E+04$ & $5.88 E+04$ & $5.72 E+04$ & $5.55 E+04$ & $5.40 E+04$ & $5.24 E+04$ & $5.09 E+04$ & $4.95 E+04$ & $4.81 E+04$ \\
\hline Pu240 & $1.65 E+03$ & $1.48 E+03$ & $1.33 E+03$ & $1.20 E+03$ & $1.08 E+03$ & $9.72 E+02$ & $8.75 E+02$ & $7.87 E+02$ & $7.08 E+02$ \\
\hline Pu241 & $2.91 E-02$ & $2.74 E-02$ & $2.53 \mathrm{E}-02$ & $2.33 \mathrm{E}-02$ & $2.15 E-02$ & $1.98 \mathrm{E}-02$ & $1.83 \mathrm{E}-02$ & $1.68 E-02$ & $1.55 E-02$ \\
\hline
\end{tabular}




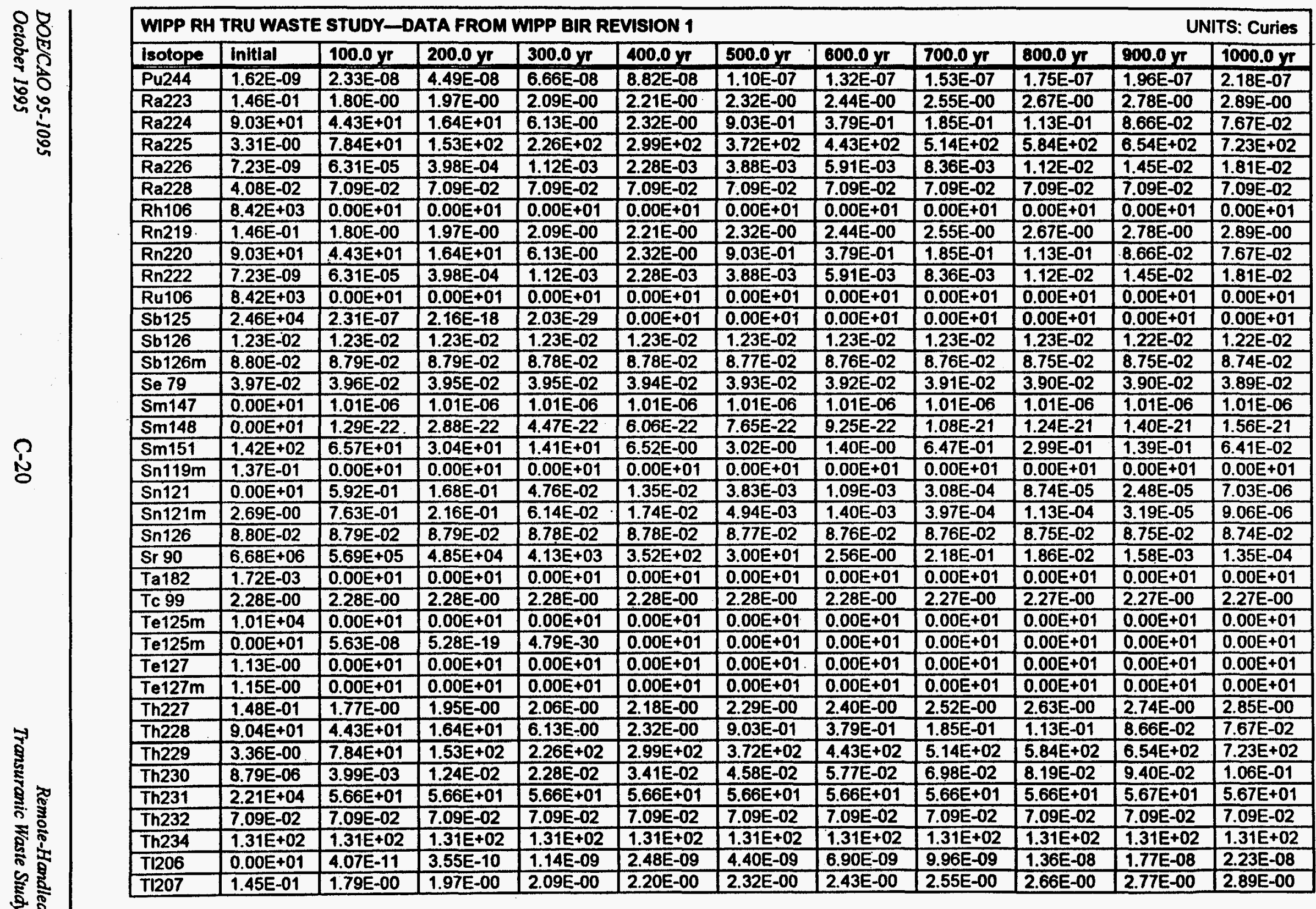




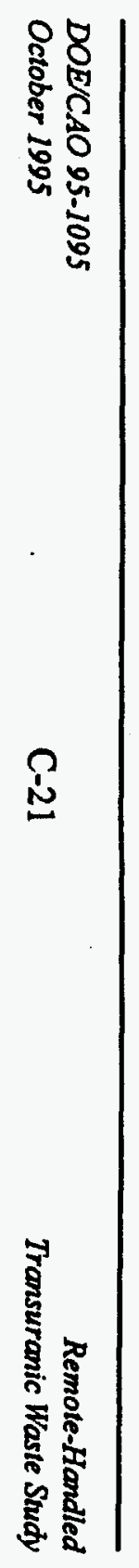

\begin{tabular}{|c|c|c|c|c|c|c|c|c|c|}
\hline \multicolumn{8}{|c|}{ WIPP RH TRU WASTE STUDY-DATA FROM WIPP BIR REVSION $i$} & \multicolumn{2}{|c|}{ UNITS: Curies } \\
\hline Isotope & $2000.0 \mathrm{yr}$ & $3000.0 y$ & $4000.0 \mathrm{yr}$ & $5000.0 \mathrm{yr}$ & $6000.0 \mathrm{yr}$ & $7000.0 \mathrm{yt}$ & $8000.0 \mathrm{yr}$ & $8000.0 \mathrm{yT}$ & $10000.0 y$ \\
\hline Pu242 & 1.47E-01 & 1.47E-01 & 1.47E-01 & 1.47E-01. & $1.46 \mathrm{E}-01$ & $1.46 E-01$ & $1.46 E-01$ & $1.46 E-01$ & $1.45 E-01$ \\
\hline Pu244 & $4.34 E-07$ & $6.49 E-07$ & $8.64 E-07$ & $1.08 E-06$ & $1.29 E-06$ & 1.51E-06 & $1.72 E-06$ & $1.93 E-06$ & $2.15 E-06$ \\
\hline $\operatorname{Ra223}$ & $4.06 \mathrm{E}-00$ & $5.16 \mathrm{E}-00$ & $6.24 E-00$ & $7.30 \mathrm{E}-00$ & $8.34 E-00$ & $9.36 \mathrm{E}-00$ & $1.04 E+01$ & $1.13 E+01$ & $1.23 E+01$ \\
\hline Ra224 & $7.09 E-02$ & $7.09 \mathrm{E}-02$ & $7.09 \mathrm{E}-02$ & $7.09 E-02$ & $7.09 E-02$ & $7.09 E-02$ & $7.09 \mathrm{E}-02$ & $7.09 E-02$ & $7.09 E-02$ \\
\hline Ra225 & $1.38 E+03$ & $1.98 E+03$ & $2.52 E+03$ & $3.02 E+03$ & & $3.88 E+03$ & $4.25 E+03$ & $4.59 E+03$ & $4.89 E+03$ \\
\hline Ra226 & $7.22 E-02$ & $1.51 \mathrm{E}-01$ & $2.46 E-01$ & $3.52 E-01$ & $4.67 E-01$ & $5.88 \mathrm{E}-01$ & $7.12 E-01$ & $8.41 E-01$ & $9.72 E-01$ \\
\hline $\operatorname{Ra} 228$ & $7.09 \mathrm{E}-02$ & $7.09 E-02$ & $7.09 \mathrm{E}-02$ & $7.09 E-02$ & 7.09E-02 & $7.09 \mathrm{E}-02$ & $7.09 E-02$ & $7.09 \mathrm{E}-02$ & $7.09 \mathrm{E}-02$ \\
\hline Rh106 & & 0.00 & & $0.00 E+01$ & $0.00 E+01$ & $0.00 E+01$ & $0.00 E+01$ & $0.00 E+01$ & $0.00 E+01$ \\
\hline Rn219 & 4.06 & 5.16 & 6.24 & $7.30 \mathrm{E}-00$ & & & & & \\
\hline Rn220 & 7.09E-02 & $7.09 \mathrm{E}-02$ & $7.09 E-02$ & $7.09 E-02$ & $7.09 \mathrm{E}-02$ & $7.09 E-02$ & $7.09 \mathrm{E}-02$ & $7.09 E-02$ & $7.09 E-02$ \\
\hline Rn222 & $7.22 E-02$ & 1.51E-01 & $2.46 \mathrm{E}-01$ & & & & $7.12 \mathrm{E}-01$ & 8.41E-01 & $9.72 \mathrm{E}-01$ \\
\hline Ru106. & & $E+01$ & +01 & +01 & +01 & +01 & $=+01$ & $=01$ & $=01$ \\
\hline Sb125 & $0.00 E+01$ & $=+01$ & $E+01$ & +01 & $=+01$ & +01 & $E+01$ & $E+01$ & $E+01$ \\
\hline Sb126 & $1.22 \mathrm{E}-02$ & $1.21 \mathrm{E}-02$ & $1.20 \mathrm{E}-02$ & $1.19 E-02$ & $1.18 E-02$ & $1.17 E-02$ & $1.17 E-02$ & $1.16 E-02$ & $1.15 E-02$ \\
\hline Sb126m & & & & & & & & & \\
\hline Se 79 & & & & & & & & & \\
\hline Sm147 & 1.01 & 1.01 & 1.0 & 1.0 & 1.0 & $1.01 \mathrm{E}-06$ & 1.01E-06 & 1.01E-06 & 1.01E-06 \\
\hline$S \operatorname{sm148}$ & & 4.75 & & & & & & & $1.59 \mathrm{E}-20$ \\
\hline Sm151 & & 1.3 & & -15 & & -22 & & -28 & +01 \\
\hline Sn119m & $0.00 E+01$ & $0.00 E+01$ & & 01 & -01 & +01 & +01 & $=01$ & $E+01$ \\
\hline Sn121 & & $7.97 t$ & 2.69 & 28 & +01 & $E+01$ & $0.00 E+01$ & $0.00 E+01$ & $0.00 E+01$ \\
\hline Sn121m & & & & & +01 & & & & \\
\hline $\operatorname{Sn} 126^{\circ}$ & & & & 8.5 & & -02 & & -02 & -02 \\
\hline Sr 90 & $2.72 \mathrm{E}-15$ & $5.49 \mathrm{E}-26$ & $0.00 E+01$ & $0.00 E+01$ & $0.00 \mathrm{E}+01$ & $0.00 E+01$ & $0.00 E+01$ & $0.00 E+01$ & $0.00 E+01$ \\
\hline Ta182 & & & & & & +01 & $E+01$ & $E+01$ & $0.00 E+01$ \\
\hline Tc 99 & & & & & & & & & -00 \\
\hline Te125m & 01 & +01 & & +01 & & +01 & +01 & +01 & $\mathrm{E}+01$ \\
\hline Te125m & $0.00 E+01$ & $0.00 E+01$ & $0.00 E+01$ & $0.00 E+01$ & $0.00 \mathrm{E}+01$ & $0.00 E+01$ & $0.00 E+01$ & $0.00 E+01$ & $0.00 E+01$ \\
\hline Te127 & $0.00 E+01$ & $0.00 E+01$ & 0.00 & $0.00 E+01$ & +01 & $=01$ & $E+01$ & $0.00 \mathrm{E}+01$ & $0.00 E+01$ \\
\hline Te127m & & & & & & +01 & +01 & +01 & $E+01$ \\
\hline Th227 & & & & & & & $E+01$ & $E+01$ & $1.21 E+01$ \\
\hline Th228 & $7.09 E-02$ & $7.09 \mathrm{E}-02$ & $7.09 E-02$ & $7.09 E-02$ & $7.09 \mathrm{E}-02$ & $7.09 \mathrm{E}-02$ & $7.09 \mathrm{E}-02$ & $7.09 \mathrm{E}-02$ & $7.09 \mathrm{E}-02$ \\
\hline Th229 & $1.38 E+03$ & $1.98 E+03$ & 2.52 & $3.02 E+03$ & 3.47 & $E+03$ & $4.25 E+03$ & $4.59 E+03$ & $4.89 E+03$ \\
\hline Th230 & & & & & & & $1.00 \mathrm{E}-00$ & $1.14 E-00$ & $1.28 \mathrm{E}-00$ \\
\hline & & $5.68 E+01$ & & $5.69 E+01$ & & & $5.71 \mathrm{E}+01$ & $E+01$ & $5.71 E+01$ \\
\hline Th232 & $7.09 E-02$ & $7.09 \mathrm{E}-02$ & $7.09 E-02$ & $7.09 \mathrm{E}-02$ & $7.09 \mathrm{E}-02$ & $7.09 \mathrm{E}-02$ & $7.09 \mathrm{E}-02$ & $7.09 \mathrm{E}-02$ & $7.09 \mathrm{E}-02$ \\
\hline Th234 & $1.31 E+02$ & $1.31 E+02$ & $1.31 E+02$ & $1.31 E+02$ & $1.31 E+02$ & $1.31 E+02$ & $1.31 E+02$ & $1.31 E+02$ & $1.31 E+02$ \\
\hline$T$ & $9.52 \mathrm{E}-08$ & $1.99 \mathrm{E}-07$ & $3.24 \mathrm{E}-07$ & $4.65 \mathrm{E}-07$ & $6.16 E-07$ & $7.75 \mathrm{E}-07$ & $9.40 \mathrm{E}-07$ & $1.11 E-06$ & $1.28 E-06$ \\
\hline
\end{tabular}




\begin{tabular}{|c|c|c|c|c|c|c|c|c|c|c|c|}
\hline isotope & Initlal & $100.0 y$ & $200.0 \mathrm{yr}$ & $300.0 \mathrm{yr}$ & $400.0 \mathrm{yr}$ & $500.0 \mathrm{y}$ & $600.0 \mathrm{y}$ & $700.0 \mathrm{yr}$ & $800.0 \mathrm{y}$ & $900.0 \mathrm{yT}$ & $1000.0 \mathrm{yr}$ \\
\hline T1208 & $3.24 E+01$ & $1.59 E+01$ & $5.91 E=00$ & $2.20 \mathrm{E}-00$ & $8.33 E-01$ & $3.25 E-01$ & $1.36 E-01$ & 6.65E-02 & 4.07E-02 & 3.11E-02 & $2.76 E-02$ \\
\hline $\mathrm{T} 1209$ & $7.08 E-02$ & $1.65 \mathrm{E}-00$ & $3.21 E-00$ & 4.75E-00 & $6.28 E-00$ & $7.80 \mathrm{E}-00$ & $9.31 E-00$ & $1.08 \mathrm{E}+01$ & $1.23 E+01$ & $1.37 \mathrm{E}+01$ & $1.52 E+01$ \\
\hline U232 & $1.16 E+02$ & $4.30 \mathrm{E}+01$ & $1.59 E+01$ & $5.90 \mathrm{E}-00$ & $2.18 \mathrm{E}-00$ & 8.09E-01 & $3.00 \mathrm{E}-01$ & 1.11E-01 & $4.12 E-02$ & $1.52 E-02$ & 5.65E-03 \\
\hline U234 & 4.18E-01 & $7.34 E-00$ & $1.05 E+01$ & $1.19 E+01$ & $1.26 E+01$ & $1.29 E+01$ & $1.31 E+01$ & $1.32 E+01$ & $1.33 E+01$ & $1.33 E+01$ & $1.34 \mathrm{E}+01$ \\
\hline U235 & $5.66 E+01$ & $5.66 E+01$ & $5.66 E+01$ & $5.66 E+01$ & $5.66 E+01$ & $5.66 E+01$ & $5.66 E+01$ & $5.66 E+01$ & $5.66 E+01$ & $5.67 E+01$ & $5.67 E+01$ \\
\hline U236 & 4.11E-04 & $6.18 E-03$ & $1.21 E-02$ & $1.80 \mathrm{E}-02$ & $2.38 E-02$ & $2.95 E-02$ & $3.52 E-02$ & $4.08 E-02$ & $4.64 E-02$ & $5.19 \mathrm{E}-02$ & 5.74E-02 \\
\hline U237 & $2.22 E-01$ & $1.73 E-03$ & $1.40 \mathrm{E}-05$ & $4.48 E-07$ & 4.18E-07 & 4.81E-07 & 5.33E-07 & 5.74E-07 & 6.07E-07 & 6.32E-07 & 6.52E-07 \\
\hline U238 & $1.31 E+02$ & $1.31 E+02$ & $1.31 E+02$ & $1.31 E+02$ & $1.31 E+02$ & $1.31 E+02$ & $1.31 E+02$ & $1.31 E+02$ & $1.31 E+02$ & $1.31 E+02$ & $1.31 E+02$ \\
\hline U240 & $1.62 \mathrm{E}-09$ & $2.33 E-08$ & $4.49 E-08$ & $6.65 E-08$ & 8.81E-08 & $1.10 E-07$ & 1.31E-07 & $1.53 E-07$ & $1.75 E-07$ & $1.96 \mathrm{E}-07$ & 2.18E-07 \\
\hline Y90 & $6.68 \mathrm{E}+06$ & $5.69 \mathrm{E}+05$ & $4.85 E+04$ & $4.13 E+03$ & $3.52 E+02$ & $3.00 E+01$ & $2.56 E-00$ & $2.18 E-01$ & 1.86E-02 & $1.58 \mathrm{E}-03$ & $1.35 E-04$ \\
\hline Zr 93 & $5.14 E-01$ & $5.14 E-01$ & $5.14 \mathrm{E}-01$ & $5.14 E-01$ & 5.14E-01 & 5.14E-01 & $5.14 E-01$ & $5.14 \mathrm{E}-01$ & $5.14 E-01$ & $5.14 \mathrm{E}-01$ & $5.14 E-01$ \\
\hline Zr 95 & $4.60 E+01$ & $0.00 E+01$ & $0.00 E+01$ & $0.00 E+01$ & $0.00 E+01$ & $0.00 E+01$ & $0.00 E+01$ & $0.00 E+01$ & $0.00 E+01$ & $0.00 E+01$ & $0.00 E+01$ \\
\hline
\end{tabular}




\begin{tabular}{|c|c|c|c|c|c|c|c|c|c|}
\hline \multicolumn{8}{|c|}{ WIPP RH TRU WASTE STUDY - DATA FROM WIPP BIR REVISION 1} & \multicolumn{2}{|c|}{ UNITS: Curies } \\
\hline Isotope & $2000.0 \mathrm{yr}$ & $3000.0 \mathrm{yr}$ & $4000.0 \mathrm{yr}$ & $5000.0 \mathrm{yr}$ & $6000.0 \mathrm{yr}$ & $7000.0 \mathrm{yr}$ & $8000.0 \mathrm{r}$ & $9000.0 \mathrm{rr}$ & $10000.0 \mathrm{yz}$ \\
\hline T1207 & 4.05E-00 & $5,15 E-00$ & 6.23E-00 & $7.28 E-00$ & 8.32E-00 & 9.34E-00 & $1.03 E+01$ & $1.13 E+01$ & $1.23 E+01$ \\
\hline T1208 & $.55 E-02$ & $2.55 E-02$ & $2.55 E-02$ & $2.55 E-02$ & $2.55 E-02$ & $2.55 E-02$ & $2.55 E-02$ & $2.55 E-02$ & $2.55 \mathrm{E}-02$ \\
\hline T1209 & $2.90 E+01$ & $4.15 E+01$ & $5.29 E+01$ & $6.33 E+01$ & $7.28 E+01$ & $8.14 E+01$ & $8.92 \mathrm{E}+01$ & $9.63 E+01$ & $1.03 E+02$ \\
\hline U232 & $2.75 \mathrm{E}-07$ & $1.34 \mathrm{E}-11$ & $6.52 E-16$ & $3.17 \mathrm{E}-20$ & $1.55 \mathrm{E}-24$ & $7.53 E-29$ & $0.00 E+01$ & $0.00 E+01$ & $0.00 E+01$ \\
\hline $\mathrm{U} 233$ & $E+03$ & $8.46 E+03$ & $8.42 E+03$ & $E+03$ & $8.35 E+03$ & $8.31 E+03$ & $8.28 E+03$ & $8.24 E+03$ & $8.20 E+03$ \\
\hline U234 & $1.37 E+01$ & $1.40 E+01$ & $1.43 E+01$ & $1.47 E+01$ & $1.50 E+01$ & $1.53 E+01$ & $1.57 E+01$ & $1.60 E+01$ & $1.63 E+01$ \\
\hline U235 & $5.67 E+01$ & $5.68 \mathrm{E}+01$ & $5.68 E+01$ & $5.69 E+01$ & $5.69 E+01$ & $5.70 E+01$ & $5.71 E+01$ & $5.71 E+01$ & $5.71 E+01$ \\
\hline $\mathrm{U} 236$ & & & & & $2.68 \mathrm{E}-01$ & $8 E-01$ & $3.26 \mathrm{E}-01$ & $3.50 E-01$ & $3.72 \mathrm{E}-01$ \\
\hline U237 & $6.96 \mathrm{E}-07$ & $6.54 E-07$ & $6.05 E-07$ & $5.57 \mathrm{E}-07$ & $5.14 \mathrm{E}-07$ & $4.74 E-07$ & $4.37 \mathrm{E}-07$ & 4.02E-07 & $3.71 E-07$ \\
\hline U238 & $1.31 E+02$ & $1.31 E+02$ & $1.31 \mathrm{E}+02$ & $1.31 E+02$ & $1.31 E+02$ & $1.31 E+02$ & $1.31 \mathrm{E}+02$ & $1.31 E+02$ & $1.31 E+02$ \\
\hline U240 & $4.33 \mathrm{E}-07$ & $6.49 \mathrm{E}-07$ & $8.63 \mathrm{E}-07$ & $1.08 \mathrm{E}-06$ & $1.29 \mathrm{E}-06$ & $1.51 E-06$ & $1.72 \mathrm{E}-06$ & $1.93 \mathrm{E}-06$ & $2.14 E-06$ \\
\hline Y90 & & & $0.00 E+01$ & $0.00 E+01$ & $0.00 \mathrm{E}+01$ & $0.00 E+01$ & $0.00 E+01$ & $0.00 E+01$ & $0.00 E+01$ \\
\hline Zr93 & $5.14 \mathrm{E}-01$ & $5.13 E-01$ & 5.13E-01 & 5.13E-01 & $5.13 E-01$ & $5.12 \mathrm{E}-01$ & $5.12 \mathrm{E}-01$ & 5.12E-01 & $5.12 \mathrm{E}-01$ \\
\hline Zr 95 & $0.00 E+01$ & $0.00 E+01$ & $0.00 E+01$ & $0.00 E+01$ & $0.00 E+01$ & $0.00 E+01$ & $0.00 E+01$ & $0.00 E+01$ & $0.00 E+01$ \\
\hline
\end{tabular}




\section{APPENDIX D}

\section{GAS GENERATION MECHANISMS}




\section{APPENDIX D \\ GAS GENERATION MECHANISMS}

The three primary gas generation mechanisms expected to be involved in the degradation of TRU wastes over time in the WIPP repository include:

- Metal corrosion (of iron and aluminum alloys);

- Microbial degradation (of cellulose, and perhaps rubber and plastic); and

- Alpha radiolysis (of water in the waste and brine, and cellulose, rubber, and plastic).

From the standpoint of gas generation for the WIPP repository, the most important mechanisms are (1) corrosion (specifically anoxic corrosion) of steels and other iron alloys, as well as aluminum alloys; and (2) microbial degradation (specifically anaerobic microbial degradation) of cellulosse, and perhaps rubber and plastic. Radiolysis studies indicate that gas generation rates from alpha radiolysis are not as significant as compared to the rates expected from anoxic corrosion and anaerobic microbial degradation [Brush, 1995].

\section{Corrosion}

Corrosion of metals in the WIPP disposal rooms may produce significant amounts of gas as well as consume significant amounts of water. The quantity of gas production, or water consumption, is directly dependent on two major factors: (1) the amount of water present in the waste at the time of emplacement and/or the amount of brine that enters the repository after closure and (2) the quantity of corrodible metals present in the waste. The WIPP WAC limits the amount of residual liquids that can be present in TRU waste to 1 volume percent of the internal container or an aggregate amount of residual liquid $<1$ volume percent of the external container [DOE, 1991]. As shown in Table D-1, there are substantial quantities of corrodible metals expected in the WIPP inventory. Table D-1 shows the distribution of these corrodible metals for both the CH-TRU and RH-TRU waste inventories. 
Table D-1. CH and RH Corrodible Metal Waste Material Parameters

\begin{tabular}{|c|c|c|c|}
\hline \multicolumn{1}{|c|}{ Parameter } & CH (kg) & RH (kg) & Total (kg) \\
\hline Iron. Metal Waste & $1.5 \times 10^{7}$ & $6.7 \times 10^{5}$ & $1.6 \times 10^{7}$ \\
\hline Aluminum Metal Waste & $2.1 \times 10^{6}$ & $1.3 \times 10^{5}$ & $2.2 \times 10^{6}$ \\
\hline Waste Packaging & $2.5 \times 10^{7}$ & $1.8 \times 10^{7}$ & $4.3 \times 10^{7}$ \\
\hline Total & $4.2 \times 10^{7}$ & $1.9 \times 10^{7}$ & $6.1 \times 10^{7}$ \\
\hline
\end{tabular}

a. RH-TRU waste packaging includes $3.2 \mathrm{E}+06 \mathrm{~kg}$ for all canisters and $1.5 \mathrm{E}+07 \mathrm{~kg}$ for all shield plugs [DOE, 1995].

There are two corrosion mechanisms that can occur in the WIPP disposal rooms, oxic corrosion and anoxic corrosion. Oxic corrosion of the corrodible metals in the waste inventory will consume the oxygen in the disposal rooms following emplacement of the WIPP seal systems. After the depletion of oxygen initially present, anoxic corrosion of these same materials will dominate; this will produce hydrogen and consume water at rates that will depend on the amount of brine present [Brush, 1995]. These two mechanisms are described in detail below.

Oxic corrosion is expected to have a minimal effect on the gas and water content of the WIPP repository. This is due primarily to the sealed nature of the repository after closure and the limited ability for additional oxygen to be generated. Based on estimates of the quantity of steel in the CH-TRU waste drums to be emplaced in the WIPP repository, oxygen trapped in the mine air at the time of closure will only be sufficient to oxidize about 0.4 to 1.1 percent of the drums, depending on the initial void volume assumed [Brush and Anderson, 1989]. With the inclusion of RH-TRU corrodible metals from the waste and waste packages, the rate of oxygen depletion will increase. The amount of oxygen consumed will remain the same. The importance of oxic corrosion will also depend on the rate of oxygen production from alpha radiolysis of the water in the waste and brine [Brush, 1995]. The radiolytic oxygen production rate depends on the quantity of brine, the initial water in the waste, and the concentrations of alpha-emitting radionuclides in the TRU waste. Estimates of the available oxygen initially present in the disposal rooms after closure indicate that the duration of oxic corrosion of steels and iron metals will be relatively short and of low consequence 
to the production of gas [Lappin et al., 1989]. Therefore, oxic corrosion is not considered significant in the comparison of CH-TRU and RH-TRU waste.

Anoxic corrosion of iron and aluminum alloys in the TRU waste has the potential to consume water and produce hydrogen, assuming several repository conditions are applicable. These conditions include (1) sufficient water is present in the waste at the time of emplacement or sufficient quantities of brine enter the WIPP disposal rooms after closure; (2) major microbial degradation and concomitant passivation does not occur; and (3) if major microbial degradation and concomitant passivation does occur, consumption of carbon dioxide or hydrogen sulfide depassivates the iron metals and steels present in the waste. However, if sufficient brine is available, microbial degradation could produce carbon dioxide and/or hydrogen sulfide (in addition to other gases), which could passivate steel and other iron-base alloys and thus prevent additional hydrogen production and water consumption [Brush, 1995].

Laboratory studies of anoxic corrosion have been carried out for the WIPP. Project at Pacific Northwest Laboratories (PNL) since November 1989. PNL conducted various experiments for periods of 3 to 24 months at low pressures (about 5 to $20 \mathrm{~atm}$ ) and high pressures (about. 36 to $73 \mathrm{~atm}$ ) on iron metals similar to those expected to be emplaced in WIPP. Low-pressure experiments were conducted to determine the effects of humid and inundated conditions, the composition of the gaseous phase, and different steel alloys on the hydrogen production and corrosion rates. Highpressure experiments were conducted to determine the effects of pressure, gaseous-phase composition, and different steel alloy on the corrosion rates. As a result of these experiments, PNL concluded that anoxic corrosion of iron alloys present in TRU waste and in contact with brines at a neutral $\mathrm{pH}$ and at low pressure will occur at a rate of $0.99 \mu \mathrm{m}$ of steel per year and produce hydrogen [Telander and Westerman, 1993].

Estimates for anoxic corrosion rates of steels and other iron alloys under inundated conditions with initially pure $\mathrm{N}_{2}$ at low pressures (about 10 to $15 \mathrm{~atm}$ ) have been used for WIPP performance assessment calculations. Because anoxic corrosion is a significant gas-generating mechanism expected to occur in the WIPP repository, gas generation rates for generation of hydrogen for both CH-TRU and RH-TRU waste are represented by minimum (0), maximum (20), and best-estimate 
values $\left(0.1 \text { moles of hydrogen }\left(\mathrm{m}^{2} \text { steel/year }\right)\right)^{1}$ [Brush, 1995]. These gas generation rates for both CH-TRU and RH-TRU wastes are identical because there are no significant differences between these waste forms that would directly influence corrosion. The comparison of the rates for $\mathrm{CH}$-TRU and RH-TRU wastes indicates that the inclusion of RH-TRU iron alloys in the repository could result in an increase from 0 to 31 percent, depending on the quantity of brine available and the occurrence of passivation [DOE, 1995].

Based on the quantities of aluminum alloys expected to be emplaced in the WIPP repository (see Table D-1), their corrosion is included when comparing CH-TRU and RH-TRU waste. The gas generation rates for both CH-TRU and RH-TRU aluminum waste is identical because there are no distinguishing attributes of this waste form that would directly influence corrosion. The inclusion of RH-TRU aluminum alloys in the repository will result in a minimal increase in the hydrogen content of the repository because of the limited amount of aluminum present in the RH-TRU waste. RH-TRU aluminum alloy waste will increase the total corrodible metal content of the repository by 0.2 percent [DOE, 1995]. RH-TRU aluminum waste could increase the amount of gas generated from zero to 0.2 percent.

In conclusion, the quantities of gas generated from iron and aluminum alloys expected in the WIPP repository can be significant, assuming inundated repository conditions. However, for anoxic corrosion the amount of gas produced will not only be dependent on the quantity of corrodible metals available, but could be limited by the amount of brine to enter the repository. The inclusion of RH-TRU waste metals, together with waste packaging and the shield plugs, will increase the total corrodible metal inventory by about 31 percent by mass. Under the current baseline, RH-TRU waste emplacement requires the use of a shield plug, which accounts for approximately 25 percent of all corrodible metals. However, DOE is currently evaluating alternative plug designs that would generate less or no gas. The comparison of CH-TRU and RH-TRU waste metals (i.e., all corrodible metals, excluding the $\mathrm{RH}$ shield plug) identifies a minimal increase in the potential amount of gas to be contributed from the RH-TRU metals.

1 Minimum, maximum, and best estimate are based on effects of $\mathrm{pH}$, pressure, and temperature from experimental data performed at SNL and PNL. Best estimates represent the most realistic value. Maximum rates are calculated from the effects of the lowest $\mathrm{pH}$, the highest total pressure, and higher temperatures than what are expected in the repository. Minimum rates are based on experimental data from passivation studies conducted at PNL [Brush, 1995]. 


\section{Microbial Degradation}

The quantities of cellulose, rubber, and plastic present in TRU waste make microbial degradation of these materials another important issue in the comparison of CH-TRU and RH-TRU wastes. Table D-2 shows the comparison of $\mathrm{CH}$ and $\mathrm{RH}$ materials that will potentially undergo microbial degradation. The most important requirements associated with this mechanism are that viable microorganisms be present and that they can survive for a significant fraction of the 10,000-year period of performance of the repository. Other important requirements include the presence of sufficient brine or water vapor for diffusive transport from the waste or rock in which the microbes occur, along with the presence and availability of sufficient electron acceptors and nutrients (especially nitrogen and phosphorus) [Brush, 1995; Brush, 1990].

Microorganisms are expected to enter the repository from several sources, including (1) association with the CH-TRU and RH-TRU waste during emplacement; (2) the surface environment, through the mine ventilation systems during operation or human intrusion; and (3) resident populations of halotolerant and halophilic bacteria in the salt crystal and brine formations. Estimates of brine inflow indicate that the small amounts of brine necessary for microbial degradation to occur will initially be present in the WIPP disposal rooms [Sandia WIPP Project, 1992]. Electron acceptors may be present in the waste or the surrounding formation in the form of nitrate ions and sulfate ions (carbon dioxide or organic acids could also serve as electron acceptors). If sufficient electron acceptors are present; they will require container rupture and the presence of brine for diffusive transport to the waste containing cellulose, rubber, and plastic. Container rupture and the presence of brine will also be necessary for transport of nutrients that may be present in the CH-TRU and RH-TRU waste [Brush, 1995]. Alpha radiation from the CH-TRU and RH-TRU waste is expected to have a very minimal effect on microbial degradation [Bamhart et al., 1980; Francis and Gillow, 1994]. Both aerobic and anaerobic microbial degradation are expected to occur in the WIPP repository; these are described in detail below. 
Table D-2. CH-TRU and RH-TRU Biodegradable Waste Material Parameters

\begin{tabular}{|l|c|c|c|}
\hline \multicolumn{1}{|c|}{ Parameter } & CH $(\mathrm{kg})$ & RH $(\mathrm{kg})$ & Total $(\mathrm{kg})$ \\
\hline Cellulose & $3.0 \times 10^{7}$ & $1.9 \times 10^{5}$ & $3.0 \times 10^{7}$ \\
\hline Rubber & $3.7 \times 10^{6}$ & $3.4 \times 10^{4}$ & $3.7 \times 10^{6}$ \\
\hline Plastic & $1.1 \times 10^{7}$ & $1.7 \times 10^{5}$ & $1.1 \times 10^{7}$ \\
\hline \multicolumn{1}{|c|}{ Total } & $4.5 \times 10^{7}$ & $3.9 \times 10^{5}$ & $4.5 \times 10^{7}$ \\
\hline
\end{tabular}

[Source: DOE, 1995]

Aerobic microbial degradation (respiration using molecular oxygen as the electron acceptor) will have a minor, indirect effect on the gas and water content of the WIPP repository. This conclusion is based on the quantity of oxygen initially present in the mine air trapped in the WIPP repository after closure [Brush, 1995].

After depletion of oxygen in the WIPP repository, anaerobic microbial degradation (respiration using nitrate ions, manganese (IV) oxides and hydroxides, iron (III) oxides and hydroxides, sulfate ions, organic acids, or carton dioxide as the electron acceptor).will begin. From the standpoint of the gas and water contents of the WIPP repository, anaerobic microbial degradation will be much more prominent than aerobic microbial degradation because there will be much more nitrate and sulfate ions and carbon dioxide present than oxygen [Brush, 1995 and 1990]. Assuming inundated conditions, anaerobic microbial degradation in the WIPP disposal rooms could generate significant gas. However, because microbial transport to the organic waste materials is brine dependent and because of the small quantity of organic waste from the RH-TRU waste inventory (1 percent by mass [DOE, 1995]), gas generation from the inclusion of RH-TRU organic wastes will be minimal.

Brookhaven National Laboratory (BNL) has conducted long-term inundated experiments on aerobic and anaerobic microbial gas generation for the WIPP Project since May 1991. The gas generation rates observed in these experiments have been used to develop the range used by SNL in the 1991 and 1992 WIPP performance assessment calculations. Estimated rates for microbial degradation of 
cellulose, rubber, and plastic for gas generation under inundated conditions range from a minimum of 0 to a maximum of 0.5 moles of gas per kilogram of organic material per year, with 0.1 as the best estimate ${ }^{2}$ [Brush, 1995]. These gas generation rates for both CH-TRU and RH-TRU wastes are identical because there are no distinguishing attributes of these waste forms that would directly influence microbial degradation. The comparison of these two waste types indicates that the inclusion of $\mathrm{RH}$ cellulose, rubber, and plastic in the repository could result in a minimal increase on the gas content of the repository from 0 to about 1 percent. The RH cellulose, rubber, and plastic will increase the total organic waste content of the repository by approximately 1 percent by mass.

\section{Radiolysis}

Radiolysis by alpha particles will not be a significant mechanism for gas generation in the WIPP repository [Brush, 1995]. Radiolysis of water in the waste and brine in the WIPP repository will consume water and produce hydrogen and perhaps limited oxygen. A variety of gases can also be produced by the alpha radiolysis of cellulose, rubber, and plastic in the waste.

Since May 1989, Argonne National Laboratory East has carried out laboratory studies of alpha radiolysis for the WIPP Project. During these experiments, alpha radiolysis of water in WIPP brines produced hydrogen and oxygen. Using hydrogen headspace analyses as a basis, ANL reported $\mathrm{G}\left(\mathrm{H}_{2}\right)$ values ( $G$ values are defined as the number of gas molecules formed per each $100 \mathrm{eV}$ of irradiation) of 1.3 and 1.4 molecules per $100 \mathrm{eV}$ for experiments with Pu-239 concentrations of $1 \times 10^{-6} \mathrm{M}$. For Pu-239 concentrations of $1 \times 10^{-4} \mathrm{M}, \mathrm{G}\left(\mathrm{H}_{2}\right)$ values of $\geq 0.8$ and 1.1 molecules per $100 \mathrm{eV}$ were reported. Quantities of hydrogen gas produced from experiments with dissolved Pu-239 concentrations of $1 \times 10^{-8} \mathrm{M}$ were too small to measure, so no $\mathrm{G}\left(\mathrm{H}_{2}\right)$ values were reported. Additional ANL experiments on the effects of alpha radiolysis at these same concentrations in WIPP brines resulted in reported $\mathrm{G}\left(\mathrm{H}_{2}\right)$ values of 1.1 to 1.4 . molecules per $100 \mathrm{eV}$ (i.e., $1.8 \mathrm{E}+03 \mathrm{moles} / \mathrm{m}^{3} / \mathrm{yr}$ ) [Reed et al., 1993].

3 Minimum, maximum, and best estimate are besed on experimental data preformed at BNL, Stanford University, and SNL. Best estimates represent the most realistic value. Maximum rates are calculated from results of experimental data preformed at SNL. Minimum rates are analogous to the minimum rates estimated for anoxic corrosion [Brush, 1995]. 
It can be concluded from these experiments that alpha radiolysis of WIPP brines will produce hydrogen and oxygen at rates much lower than the expected gas production rates for anoxic corrosion and anaerobic microbial degradation [Brush et al., 1993]. Additional evaluation by SNL suggests that alpha radiolysis of cellulose, rubber, and plastic will be minimal from the standpoint of long-term gas production in the WIPP repository [Brush, 1995]. Estimates for the production of gas from alpha radiolysis that will occur in the WIPP disposal rooms indicate that alpha radiolysis will be only a minor contributor to gas generation. In consideration of the CH-TRU and RH-TRU waste inventory, the amount of gas generated from alpha radiolysis is anticipated to be minimal. 


\section{REFERENCES}

Barnhart, B. J., E. W. Campbell, E. Martinez, D. E. Caldwell, and R. Hallett, 1980, Potential Microbial Impact on Transuranic Wastes Under Conditions Expected in the Waste Isolation Pilot Plant (WIPP), Anmual Report, October 1, 1978-September 30, 1979, LA-8297-PR, Los Alamos Scientific Laboratory, Los Alamos, New Mexico.

Brush L. H., 1990, Test Plan for Laboratory and Modeling Studies of Repository and Radionuclide Chemistry for the Waste Isolation Pilot Plant, SAND90-0266, Sandia National Laboratories, Albuquerque, New Mexico.

Brush, L. H., 1995, Systems Prioritization Method-Iteration 2, Baseline Position Paper: Gas Generation in the Waste Isolation Pilot Plant, Sandia National Laboratories, March 17, 1995.

Brush, L. H., and D. R. Anderson, 1989, Potential Effects of Chemical Reactions on WIPP Gas Water Budgets, Systems Analysis, Long-Term Radionuclide Transport, and Dose Assessments, Waste Isolation Pilot Plant (WTPP), Southeastern New Mexico, March 1989, Eds. A. R. Lappin, R. L. Hunter, D. P. Garber, and P. B. Davies, SAND89-0462, Sandia National Laboratories, Albuquerque, New Mexico.

Brush, L. H., M. A. Molecke; R. E. Westerman, A. J. Francis, J. B. Gillow, R. H. Vreeland, and D. T. Reed, 1993, "Laboratory Studies of Gas Generation for the Waste Isolation Pilot Plant," Scientific Basis for Nuclear Waste Management XVI, Materials Research Society Symposium Proceedings, Boston, Massachusetts, November 30-December 4, 1992, C. G. Interrante and R. T. Pabalan, eds., Vol. 294, pp. 335-340, Materials Research Society, Pittsburgh, Pennsylvania; SAND92-2160C.

DOE: See U.S. Department of Energy.

Francis, A. J., and J. B. Gillow, 1994, Effects of Microbial Processes on Gas Generation Under Expected Waste Isolation Pilot Plant Repository Conditions, SAND93-7036, Sandia National Laboratories, Albuquerque, New Mexico.

Lappin, A. R., R. L. Hunter, D. P. Garber, and P. B. Davies, eds., 1989, Systems Analysis, LongTerm Radionuclide Transport, and Dose Assessments, Waste Isolation Pilot Plant (WIPP), Southeastern New Mexico, March 1989, SAND89-0462, Sandia National Laboratories, Albuquerque, New Mexico.

Reed, D. T., S. Okajima, L. H. Brush, and M. A. Molecke, 1993, "Radiolytically-Induced Gas Production in Plutonium-Spiked WIPP Brine," Scientific Basis for Nuclear Waste Management XVI, Materials Research Society Symposium Proceedings, Boston MA, November 30-December 4, 1992, Vol. 294, 431-, Eds. C. G. Interrante and R. T. Pabalan, SAND92-7283C, Materials Research Society, Pittsburgh, Pennsylvania. 
Sandia WIPP Project, 1992, Preliminary Performance Assessment for the Waste Isolation Pilot Plant, December 1992, SAND92-0700, December 1992.

Telander, M. R., and R. E. Westerman, 1993, Hydrogen Generation by Metal Corrosion in Simulated Waste Isolation Pilot Plant Environments, SAND92-7347, Sandia National Laboratories, Albuquerque, New Mexico.

U.S. Department of Energy, 1991, Waste Acceptance Criteria for the Waste Isolation Pilot Plant, Revision 4.0, WIPP-DOE-069, December 1991.

U.S. Department of Energy, 1995, Waste Isolation Pilot Plant Transuranic Waste Baseline Inventory Report, Revision 1, CAO-94-1005, February 1995. 


\section{APPENDIX E}

\section{ANALYSIS SUPPORTING EVALUATION OF BRINE AND GEOCHEMICAL INTERACTIONS}




\section{APPENDIX E}

\section{ANALYSIS SUPPORTING EVALUATION OF BRINE AND GEOCHEMICAL INTERACTIONS}

1. It was assumed that the waste containers could be modeled as line sources allowing application of the monoenergetic narrow-beam radiation equation. From Shleien and Terpilak (1984),

$$
I=I_{0} \exp (-\mu x)
$$

where,

$$
\begin{aligned}
\mathbf{x}= & \text { absorber thickness }[\mathrm{cm}] \\
I_{0}= & \text { original radiation exposure rate at time zero and at the source }(x=0) \\
& {[\mathrm{rad} / \mathrm{hr}] } \\
I= & \text { attenuated radiation exposure rate }[\mathrm{rad} / \mathrm{hr}] \\
\mu= & \text { linear absorption coefficient }[\mathrm{cm}-1]=\ln 2 / \mathrm{x}_{1 / 2} \\
x_{1 / 2}= & \text { half-value layer of absorber }[\mathrm{cm}]
\end{aligned}
$$

2. Substitution for $\mu$ gives:

$$
I=I_{0} \cos \left(-\ln 2 x / x_{12}\right)
$$

3. If the extent of the zone influenced by radiation is assumed to be $10 x_{1 / 2}$, the average dose rate within this zone is given by: 


$$
\begin{aligned}
& I=\frac{\int_{0}^{10 x_{12}} I_{0} \exp \left(-\frac{\ln 2}{x_{1 / 2}} x\right) d x}{\int_{0}^{10 x_{1 / 2}} d x} \\
& I=\frac{I_{0}}{10 x_{1 / 2}}\left[\int_{0}^{10 x_{12}} \exp \left(-\frac{\ln 2}{x_{1 / 2}} x\right) d x\right] \\
& I-\frac{I_{0}}{10 x_{1 / 2}}\left(-\frac{x_{1 / 2}}{\ln 2} \exp \left(-\frac{\ln 2}{x_{1 / 2}} x\right)\right)_{0}^{10 x_{1 / 2}} \\
& I-\frac{I}{1} / 10 \ln 2[\operatorname{lexp}(-10 \ln 2)-\exp (0)]
\end{aligned}
$$

4. In equation (7) $\mathrm{I}_{0}$ will decay as a function of time, giving the average dose rate in the zone of influence as a function of time as,

$$
I(t)=0.14413 I_{0}(t)
$$

where,

$$
\begin{aligned}
& I_{0}(t)=I_{0} \exp \left(-\ln 2 t / t_{1 / 2}\right) \\
& t=\text { time since disposal [years] } \\
& t_{1 / 2}=\text { radionuclide half-life [years] }
\end{aligned}
$$


yielding,

$$
I(t)=0.14413 I_{0} \exp \left(-\ln 2 t / t_{12}\right)
$$

5. Calculation of the average dose absorbed by the formation within the zone of influence as a function of time is given by,

$$
\begin{aligned}
& D(t)=\int_{0}^{t} 1(t) d t \\
& D(t)=\int_{0}^{t} 0.14413 I_{0} \exp \left(-\ln 2 t / t_{12}\right) d t \\
& D(t)=0.14413 I_{0} \int_{0}^{1} \cos \left(-\ln 2 t / t_{2 / 2}\right) t t \\
& D(t)=\frac{-0.14413 I_{0} t_{12}}{\ln 2}\left(\exp \left(\frac{-\ln 2}{t_{1 / 2}} t\right)\right)_{0}^{t} \\
& D(t)=\frac{-0.14413 I_{0} t_{12}}{\ln 2}\left(\exp \left(\frac{-\ln 2}{t_{12}} t\right)-\exp (0)\right) \\
& D(t)=-0.20794 I_{0} t_{1 / 2}\left(\exp \left(-0.69315 t t_{12}\right)^{-1}\right)
\end{aligned}
$$


6. The gamma-emitting radionuclide with the shortest half-life will yield a conservative result from equation (15). Of the 23 radionuclides considered to be important in PA calculations, 5 have gamma rays as one of their primary emissions. These are listed in Table E-1. As shown in the table, Cs-137 occurs in the greatest abundance and with the highest energy; therefore, its half-life of 30 years was selected for use in equation (15), which becomes,

$$
D(t)=-6.23820 I_{0}(\exp (-0.02310 t)-1)
$$

7. The term $I_{0}$ is presented in $[\mathrm{rad} / \mathrm{hr}]$; therefore, a conversion to a yearly rate must be incorporated into equation (16), which then becomes,

$$
D(t)=-54,684.06 I_{0}(\exp (-0.02310 t)-1)
$$

where, $I_{0}=[\mathrm{rad} / \mathrm{hr}]$. 


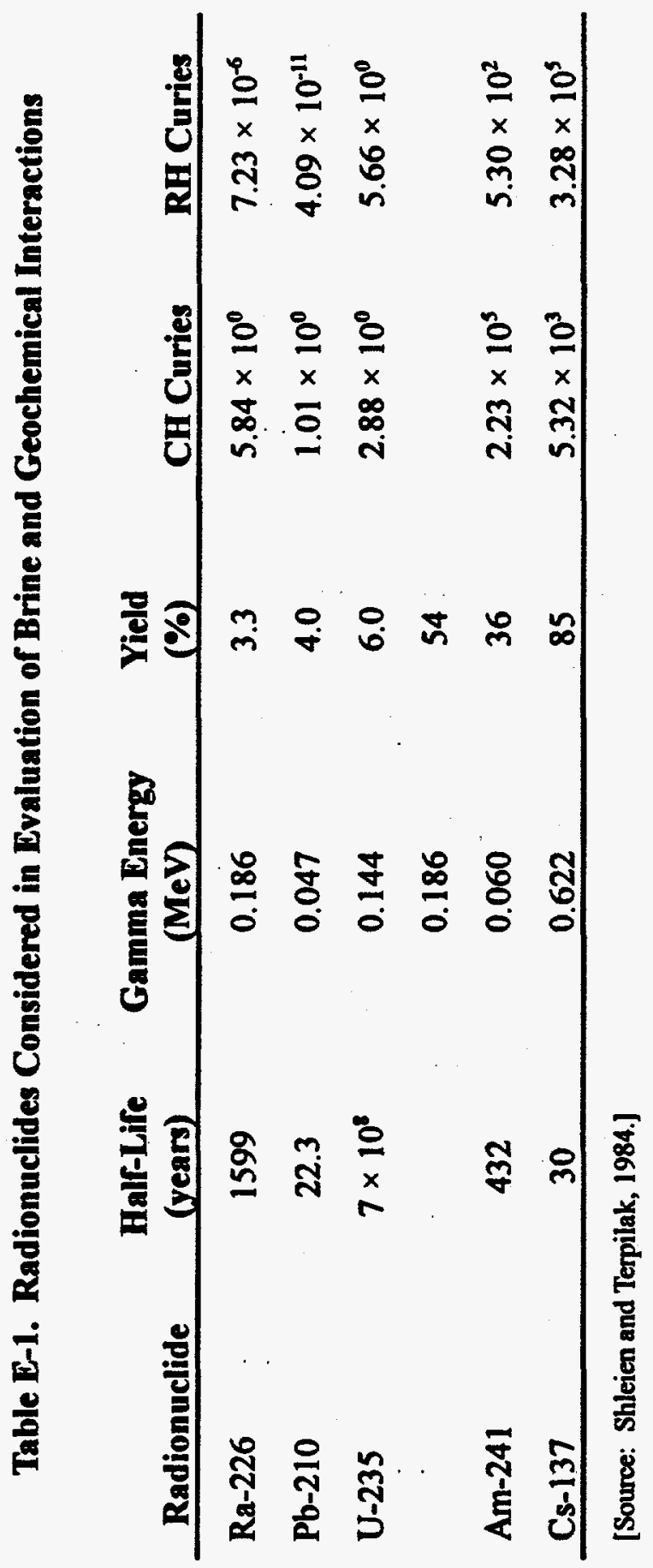




\section{REFERENCE}

Shleien and Terpilak, 1984, Health Physics Handbook. 